The Limitations of Retirement Plan Law

By Peter M. van Zante

September 2004

Please provide comments to:

Peter M. van Zante

Professor of Law

Chapman University School of Law

One University Drive

Orange, CA 92866-1005

Office voice: (714) 628-2608

Office fax: (714) 628-2576

Email: vanzante@chapman.edu

Copyright 2004. Peter M. van Zante. All rights reserved. 


\section{Abstract: The Limitations of Retirement Plan Law}

It is widely believed that employers determine whether or not their employees receive retirement benefits and the type and amount of any benefits that are received. This belief is mistaken. While sponsorship of a retirement plan is a voluntary choice on the part of the sponsoring employer and the sponsoring employer directly controls the type of plan and the level of benefits provided, the employer's choices on these matters are controlled by its employees' preferences for different forms of compensation. An employer must spend the funds available for employee compensation so as to provide its employees with those forms of compensation that the employees value most highly. An employer includes retirement benefits in its employees' compensation packages when the employees prefer those benefits to other forms of compensation. In addition, in the long run, employees bear the costs of their retirement benefits. These facts mean that employees receive the retirement benefits that they want and are willing to pay for.

This conclusion undercuts the foundation of much of the law that regulates employees' retirement benefits, which includes the Employee Retirement Income Security Act ("ERISA") and portions of the Internal Revenue Code. In general, these laws are intended to enhance the quality of retirement benefits and to increase the levels of retirement benefits received by employees, particularly by nonhighly compensated employees. Retirement plan law attempts to accomplish these purposes by requiring that retirement benefits be provided on certain specified terms and to certain categories of employees. Mandatory enhancements in the quality of retirement benefits increase the costs of the benefits; since employees must pay for this enhanced quality, fewer employees, especially lower-paid employees, pay for and receive retirement benefits. Therefore, qualitative regulation of retirement benefits tends to restrict the benefits to higher-paid employees. Requirements that benefits be provided to employees who are unwilling to bear the costs of the benefits ultimately have the perverse effect of decreasing the retirement benefits of nonhighly compensated employees. In a voluntary retirement plan system, legal rules cannot compel employees to buy more and better retirement benefits than they want. ERISA and the retirement plan provisions of the Code tend to reduce the levels of retirement benefits received by employees generally and by nonhighly compensated employees in particular. 
The Limitations of Retirement Plan Law

I. Introduction.......................................................................................................................... 1

II. Voluntary Retirement Benefits; Mandatory Retirement Plan Law........................... 11

A. Voluntary Employment and Voluntary Retirement Benefits ...................................... 11

B. Mandatory Retirement Plan Law........................................................................ 15

C. Retirement Savings and Retirement Plan Law......................................................... 19

III. Employees Control Their Retirement Benefits ................................................................ 22

A. Employees Trade Salary for Retirement Benefits ...................................................... 22

1. Employees' Preferences Determine Their Retirement Benefits ................................. 22

2. Employees' Preferences Control Their Employers' Choices ..................................... 29

3. Employee Surplus and Willing Employees ..................................................... 32

B. Employees Bear the Costs of Retirement Benefits …..................................................... 35

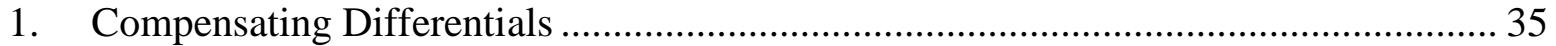

2. Employees, Customers, and Owners ................................................................... 41

C. Employer Surplus and Productivity Gains from Retirement Plans .............................. 44

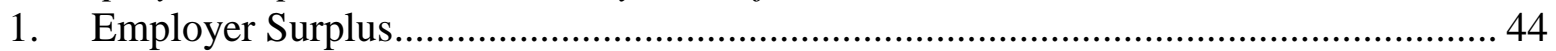

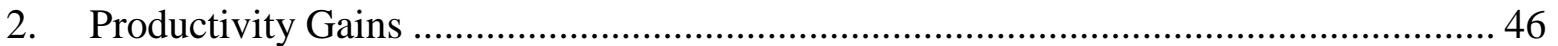

D. Retirement Plan Law and Employees' Preferences.................................................. 48

1. The Income Tax Preference for Retirement Benefits. ............................................. 49

2. Benefit Allocation Rules...................................................................................... 54

3. Reluctant Employees and Mandated Retirement Benefits......................................... 61

IV. Standardized Employee Benefits and Employee Preferences................................... 65

A. Employees Choose Among Standardized Employment Packages ................................ 65

B. Voluntarily Standardized Compensation Packages ...................................................... 68

C. Standardized Retirement Benefits .............................................................................. 68

1. Income Tax Law Standardizes Retirement Benefits..............................................6 69

2. Limited Escape from Standardization: The Section 401(k) Plan............................. 73

3. The Qualitative Regulation of Retirement Benefits.............................................. 76

D. Standardization of Retirement Limits Their Value and Raises Their Price.................... 78

V. The Limitations of Retirement Plan Law ............................................................................. 80

A. Qualitative Standardization Prices Lower-paid Employees out of the Retirement Plan

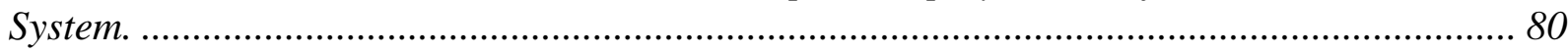


B. The Benefit Allocation Rules Have No Effect on Some (Most?) Plans........................... 83

C. By Themselves, the Benefit Allocation Rules Reduce Retirement Benefits ..................... 87

D. The Effects of the Benefit Allocation Rules Are Weak .................................................... 89

E. Reforms in the Benefit Allocation Rules That Aim To Increase Benefits for Nonhighly

Compensated Employees Will Decrease Benefits.............................................................. 93

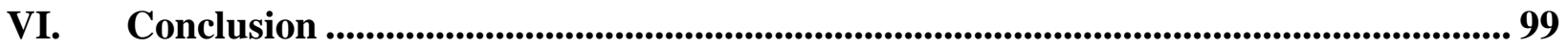


The Limitations of Retirement Plan Law

\section{Introduction}

The conventional wisdom holds that the employer that sponsors a retirement plan $^{1}$ controls how employees save for retirement and how much of their compensation they receive in the form of retirement benefits: ${ }^{2}$

"Most larger employers view the provision of tax-favored pensions as a necessary part of their compensation packages, and their employees have no option but to take some of the compensation in the form of pension benefits... . [T] he choice of how and how much to save [for retirement] is largely determined by employers, not employees."3

${ }^{1}$ This article uses the terminology "retirement plan" to refer to a "tax-qualified" retirement plan that is sponsored by an employer and that provides retirement benefits to that sponsoring employer's employees. The term is used to refer only to plans that are "qualified" for special income tax treatment under Internal Revenue Code $\S \S 401$ and 501(a). I.R.C. $\S \S 401$, 501(a) (2000 \& Supp.__ 200_); see infra note 147 and accompanying text. Retirement plans include those types of plans variously referred to as pension plans, profit-sharing plans, section 401(k) plans, defined benefit plans, and defined contribution plans. See infra note 50 and accompanying text.

The retirement plans discussed in this article are also included in the term "employee pension benefit plan" as defined by the Employee Retirement Income Security Act of 1974. Employee Retirement Income Security Act of 1974, § 3(2)(A) (as amended) (CCH 2003) [hereinafter ERISA]; 29 U.S.C. $§ 1002(2)(A)$ (2000 \& Supp._200_).

This analysis is limited to plans sponsored by private, for-profit employers. Virtually all retirement plans sponsored by private, for-profit employers are subject to ERISA. ERISA $\S 4,29$ U.S.C. $\$ 1003$ (2000 \& Supp._ 200_). See generally Peter J. Wiedenbeck, ERISA's Curious Coverage 76 Wash. U. L.Q. 331 (1998). This article excludes plans that are sponsored by governmental employers, churches, and retirement savings arrangements connected with employers that are nonprofit organizations such as educational institutions. Also excluded are plans that have been the subject of collective bargaining between an employer and employees; these plans are often referred to as "union retirement plans." Many union retirement plans are included in the ERISA definition of a "multiemployer plan," a plan that covers the employees of more than one employer, and that is maintained pursuant to a collective bargaining agreement. ERISA $\S 3(37)(A), 29$ U.S.C. $§ 1002(37)(A)$ (2000 \& Supp. _ 200_).

${ }^{2}$ The term "retirement benefits" refers to the legal rights that employees receive while they are actively employed and participating in their employer's retirement plan. These retirement benefit rights entitle an employee to receive payments of retirement income at some future date, typically after the employee retires from active employment. See infra note 26, and text accompanying note 36 .

${ }^{3}$ Michael J. Graetz \& Jerry L. Mashaw, True Social Security, Rethinking American Social Insurance 102-03 (Yale Univ. 1999) [hereinafter Graetz \& Mashaw]. 
However, the conventional wisdom has it backwards; employees, not employers, control how much they save for retirement and, subject to constraints of retirement plan law, ${ }^{4}$ how they save for retirement.

This rejection of the conventional wisdom rests on three facts about our private retirement plan system. First, the system is voluntary; employers are not legally required to provide employees with retirement benefits, nor are employees required to save for their own retirement. Second, employees' preferences about jobs and compensation determine the jobs they choose and the forms of compensation included in the compensation packages their employers provide to them. And third, employees bear most of the costs of their retirement benefits through reductions in the amounts of salary or other forms of compensation they receive; these reductions that pay for retirement benefits are referred to as the "implicit price" of the benefits. ${ }^{5}$ (For simplicity, the discussion will refer to the implicit price as being paid by a reduction in the amount of salary that an employee receives. ${ }^{6}$ This article creates a set of specifically defined terms; a collection of short summaries of these definitions appears in a footnote. ${ }^{7}$ )

These three facts imply the thesis advanced here: employees' preferences and choices control the amounts of retirement benefits that they receive. The logic begins with the commonplace that retirement plan sponsorship is voluntary on the part of an employer. This means that some employers offer employees compensation packages that include retirement benefits; other employers for otherwise equivalent jobs offer no retirement benefits but offer larger salaries instead. An employee who chooses employment that includes compensation in the

${ }^{4}$ Retirement plan law refers to ERISA and to those provisions of the Internal Revenue Code that govern the taxation of retirement savings and retirement plans. See ERISA $\$ \S 1-4402$, 29 U.S.C. $\S \S 1001-$ (2000 \& Supp. 20__); see e.g., I.R.C. \$\$ 401-420 (2000 \& Supp. 200_). See generally Stein, Agenda for Reform, supra note, at 647-49 (discussing the relationship between Title I of ERISA and the IRC).

${ }^{5}$ See infra note 26, and text and Example 1 accompanying notes 62-66. The price of retirement benefits is implicit because retirement benefits provided by an employer-sponsored plan are not purchased in a market in which an explicit price is established. The implicit price of retirement benefits can be determined only through economic and statistical studies of the components of different employees' compensation packages. See id.

6 "Salary" refers to money compensation paid to an employee at about the same time that the employee renders services to the employer.

${ }^{7}$ See infra note 26. 
form of retirement benefits obviously has agreed to accept those benefits. That employee has also agreed to pay the implicit price of her retirement benefits by accepting a lower salary. An employee chooses compensation in the form of retirement benefits when she prefers those benefits instead of some additional amount of salary. When an employee chooses a job, she selects a compensation package that provides her with the amount of retirement benefits that she wants and that she is willing to pay for. Competition for the most productive employees compels employers to provide employees with the forms of compensation that the employees value most highly; therefore, employers respond to their employees' preferences and design compensation packages that include the proportion of salary and retirement benefits that the employees prefer. In this way employees' preferences and choices determine the decisions that their employers make about including retirement benefits in compensation packages and thereby control the amounts of retirement benefits that the employees receive.

Employees control their own retirement benefits. This theory squarely refutes the conventional wisdom that an employer controls its employees' retirement benefits. ${ }^{8}$ Rejection of the conventional wisdom is important because the conventional wisdom leads to a misunderstanding about the potential of retirement plan law to provide employees with more and better retirement benefits. If it is believed that an employer controls its employees' retirement benefits, then it is easy to assume that these benefits can be improved simply by a rule that requires that if an employer sponsors a retirement plan, then the plan must provide certain employees with a specified quantity of retirement benefits that are of a specified quality. ${ }^{9}$ This assumption that the law can, ipso jure, provide employees with improved retirement benefits underlies much of present day retirement plan law.

${ }^{8}$ The illusion of employer control over retirement benefits may stem from the formal structure of a retirement plan: a plan is created and administered by the employer. However an employer that sponsors a retirement plan exercises its formal control over the plan so as to provide its employees with retirement benefits that more or less conform to the employees' preferences for these benefits and for alternative forms of compensation.

${ }^{9}$ Retirement benefits are of a higher quality of retirement benefits when there is a higher likelihood that the retirement benefit rights that an employee receives while she is actively employed will actually result in her receiving retirement income payments at some future time, prototypically after she has retired from active employment. Substantial portions of retirement plan law are devoted to reduction of risks of nonpayment of retirement income. However, improvements in the quality of retirement benefits also imply that the benefits will cost more. See infra Part IV.C.3. 
The theory of employee control of retirement benefits implies a very different understanding of the potential of retirement plan law to control the quality and quantity of retirement benefits that employees receive. Employee control means that employees voluntarily purchase the amounts of retirement benefits that they want and that they are willing to pay for. As long as employees may choose among jobs and the attendant compensation packages, they will not pay for more retirement benefits than they want. When retirement plan law requires that an employer provide retirement benefits of a certain specified quality, and when benefits of that quality cost more than employees are willing to pay, employees will simply choose not to buy retirement benefits. If employees do not pay for retirement benefits, employers will not provide them with those benefits. If retirement plan law requires that a particular retirement plan provide certain employees with a certain quantity of retirement benefits, and if these employees do not want to pay for the specified level of benefits, the employees will not accept employment with the employer that sponsors the plan; the employees instead will choose employment with an employer that offers a lower level of benefits or no benefits at all. Provisions of retirement plan law that attempt to compel employees to buy more or better retirement benefits than they want will have no effect; employees will migrate to jobs that provide the amounts of retirement benefits that they are willing to pay for.

In a system of voluntary retirement plans and voluntary choices among alternative employment opportunities, the power of retirement plan law to improve the quality and quantity of retirement benefits is very limited. This article demonstrates five limitations of retirement plan law. ${ }^{10}$ First, legally mandated standardization of the quality of retirement benefits prices lowerpaid employees out of the retirement plan system. ${ }^{11}$ Retirement plan law specifies numerous minimum standards that improve the quality of employees' retirement benefit rights; for example, retirement benefits may not be forfeitable after an employee has completed seven years of employment with the employer that sponsors a retirement plan. These quality standards are uniform for all retirement plans and they increase the costs of retirement benefits. When the costs of retirement benefits increase, employees must pay higher implicit prices for those benefits. As the prices of retirement benefits rise, fewer lower-paid employees will pay for the benefits; the

\footnotetext{
${ }^{10}$ See infra Part V.

11 See infra Part V.A.
} 
private retirement plan system will increasingly become the province of higher-paid employees, which is borne out by the data about participation in retirement plans.

The remaining four limitations of retirement plan law ${ }^{12}$ are limits on the efficacy of a system of law and regulation that this article refers to as the "benefit allocation rules." 13 An important purpose of these rules is to cause retirement plans to provide more benefits to "nonhighly compensated employees"14 than these employees would otherwise receive. ${ }^{15}$ These rules include the provisions of the Internal Revenue Code that regulate the participation of employees in an employer's retirement plan, the allocation of benefits among participating employees, the rates of accrual of the benefits, and the vesting and ultimate payment of benefits. ${ }^{16}$ In the most general terms, the benefit allocation rules require a retirement plan to provide the sponsoring employer's nonhighly compensated employees with levels of benefits that are reasonably comparable to the benefit levels that are received by the employer's "highly compensated employees." ${ }^{\prime 17}$ Levels of benefits can be measured by comparing the amount that is contributed to a retirement plan for a participant in a given year with the participant's taxable compensation for that year; for example, if $\$ 2,000$ were contributed to a plan and the employee earned $\$ 20,000$ of salary, the participant would have received retirement benefits at the rate of $10 \%$ of salary. ${ }^{18}$ The benefit allocation rules can be thought of as loosely tying together the

12 See infra Parts V.B.-V.E.

${ }^{13}$ The benefit allocation rules are the I.R.C. rules that regulate a retirement plan's coverage, participation, nondiscrimination in contributions or benefits, accrual, vesting, and benefits payment. See infra note 26, and text accompanying notes 170-190.

${ }^{14}$ Nonhighly compensated employees are those employees who are not included in a category that is defined as "highly compensated employees." See Treas. Reg. § 1.401(a)(4)-12, NHCE (as amended in 1993); see infra note 26, and text accompanying notes 170-173. In general terms, highly compensated employees earn more than $\$ 90,000$ per year, or own more than 5\% of the ownership interests in the employer. See I.R.C. § 414(q) (2000 \& Supp. _ 200_); see infra note 26 , and text accompanying notes 170-173.

${ }^{15}$ The benefit allocation rules advance two policies in addition to increasing the retirement benefits received by nonhighly compensated employees. The rules are also intended to prevent abuse of the income tax preference allowed for retirement benefits and to set minimum quality standards for benefits.

${ }^{16}$ Many of the Code's provisions that regulate these topics are duplicated in ERISA as mandatory rules that specify the content of an employer's retirement plan. See infra note 163 and accompanying text. notes $170-173$.

17 See I.R.C. $\$ 414(q)$ (2000 \& Supp. _ 200_); see infra note 26, and text accompanying

${ }^{18}$ See infra text accompanying notes 182-184. Discussion of a rate or level of retirement 
benefit levels of the nonhighly and highly compensated employees who are employed by a sponsoring employer. ${ }^{19}$ By tying the benefit levels of nonhighly compensated employees to the higher benefit levels that highly compensated employees prefer, the benefit allocation rules are intended to increase benefits for nonhighly compensated employees.

The second limitation of retirement plan law that follows from employee control of retirement benefits suggests that the benefit allocation rules seldom have their intended effect of increasing benefits for nonhighly compensated employees. The second limitation holds that when the participants in a retirement plan have homogeneous preferences for retirement benefits, the benefit allocation rules have no effect on the amounts of benefits received by nonhighly compensated employees. ${ }^{20}$ Because employees choose a job that provides them with a level of retirement benefits that they are willing to pay for, retirement plans will naturally evolve to cover groups of employees who prefer the amount of benefits provided by each plan. Employees and employers sort themselves into employment matches that provide employees with the amount of retirement benefits that the employees prefer. Each plan will tend to cover a group of employees in which the nonhighly and highly compensated employees are willing to pay for about the same level of retirement benefits, that is, a group of employees who have homogeneous preferences for retirement benefits. This means that the benefit allocation rules will have no effect on many, perhaps most, retirement plans.

While it appears that in fact employees sort themselves into a retirement plan that provides the level of benefits that matches the employees' preferences, the benefit allocation rules are built on an entirely different assumption. These rules assume that retirement plans cover groups of employees with heterogeneous preferences, groups in which the highly compensated employees prefer to buy retirement benefits at higher rates than nonhighly compensated

benefits refers to the contribution as a percentage of currently taxable compensation.

${ }^{19}$ If a highly compensated employee received a retirement benefit that was $10 \%$ of her taxable compensation, the benefit allocation rules could require the retirement plan to provide one or more of the employer's nonhighly compensated employees with retirement benefits that amounted to, say, $6 \%$ of these employees' taxable compensation. In many circumstances, the benefit allocation rules do not require exact mathematical equivalence of the level of benefits provided to highly and nonhighly compensated employees. It is this loose relationship between the benefit levels of highly and nonhighly compensated employees that is described as a loose tying together of the levels. See infra note 186 and accompanying text.

${ }^{20}$ See infra Part V.B. 
employees. Since the benefit allocation rules make this assumption, it is valuable to analyze the effects that retirement plan law might have on plans that cover employee groups with heterogeneous preferences. The remaining three limitations of retirement plan law suggest that the benefit allocation rules will have either no effects or only very weak effects on the levels of benefits received by nonhighly compensated employees. The third limitation of retirement plan law holds that, by themselves, the benefit allocation rules reduce aggregate retirement benefits. ${ }^{21}$ The rules loosely tie together the benefit levels of nonhighly and highly compensated employees; the effect of this rule is not to increase benefits for nonhighlies, but to decrease the benefits that highlies are permitted to buy.

However, the benefit allocation rules do not operate entirely by themselves. The income tax portions of retirement plan law reduce an employee's tax liabilities when she receives and holds retirement benefits. This income tax preference for retirement benefits might in theory allow an employer that sponsors a retirement plan to reduce its employee compensation costs for some employees, most significantly highly compensated employees, below the amount it would incur if it paid these employees entirely with salary. Sponsorship of retirement plan might also enhance the productivity of an employer's workforce. ${ }^{22}$ If these effects create a source for funding retirement benefits for nonhighly compensated employees, then it is possible that the benefit allocation rules can cause some plans to provide some nonhighlies with more retirement benefits than they would have purchased for themselves. However, the fourth limitation of retirement plan law holds that even if the benefit allocation rules do enhance the retirement benefits of some nonhighlies, the increases in benefits are very small. ${ }^{23}$ There are a number of factors and inter-relationships that suggest that it is generally unlikely that an employer would apply any compensation cost savings or productivity gains to the purchase of retirement benefits for nonhighlies who are unwilling to buy the benefits for themselves.

${ }^{21}$ See infra Part V.C.

${ }^{22}$ The compensation cost savings that arise from an employer's sponsorship of a retirement plan are referred to as "employer surplus." See infra note 26, and see infra Part IV.C.3 and particularly Example 3 accompanying notes 135-138. Financial gains that result from sponsorship of a retirement plan are referred to as "productivity gains." See infra note 26, and see infra Part III.C.2.

${ }^{23}$ See infra Part V.D. 
The data about receipt of retirement benefits by employees show that most lower-paid employees receive low levels of retirement benefits or no benefits at all. ${ }^{24}$ These data confirm the theory that employees control the retirement benefits that they receive; since lower-paid employees are generally less willing to pay for retirement benefits, they receive fewer benefits. However, much retirement plan scholarship draws an entirely different conclusion from these data; the conventional interpretation is that the benefit allocation rules are not sufficiently rigorous. Commentators often suggest that the levels of retirement benefits provided to lowerpaid employees could be increased if the benefit allocation rules were tightened in one respect or another. The general thrust of these reform proposals is to require that the levels of retirement benefits provided to nonhighly compensated employees must more closely converge with the levels provided to highly compensated employees. The assumption underlying such proposed reforms is that they will have their intended effects, that changes in the benefit allocation rules will cause retirement plans to provide more benefits to nonhighlies. The fifth limitation of retirement plan law refutes this assumption; it holds that reforms in the benefit allocation rules that aim to increase benefits for nonhighly compensated employees will instead decrease aggregate retirement benefits. ${ }^{25}$ Reforms will either not affect or will decrease the benefits received by nonhighlies, and they will decrease the benefits received by highlies. Many observers believe that the benefit allocation rules presently do not do enough to enhance retirement benefits for lower-paid employees; the reforms that are typically proposed will only make the present situation worse.

These arguments develop in the following sequence. Part II begins with the generally accepted proposition that an employer's decision to sponsor a retirement plan is voluntary on the part of the employer. It then builds on the observation that an employee's choice of employment is voluntary and argues that when an employee has chosen employment that pays part of its compensation in the form of retirement benefits, the employee has voluntarily chosen to receive retirement benefits. Thus, the inclusion of retirement benefits in an employee's compensation package is controlled by the voluntary choices of the employer and employee.

Part III introduces a standard economic theory, the hedonic wage theory, to explain how employees' preferences determine the choices that they make about jobs and compensation;

\footnotetext{
${ }^{24}$ See infra note 165 and accompanying text.
} 
employees' preferences also determine the amounts of retirement benefits that are included in employees' compensation packages. This part then reviews the theory and evidence supporting the proposition that employees bear the costs of their retirement benefits by receiving lesser amounts of other forms of compensation. These two points, that employees voluntarily choose how much of their compensation to receive in the form of retirement benefits and that they pay for the retirement benefits that they choose, imply that employees receive the retirement benefits that they are willing to pay for. However, retirement plan law modifies this outcome in two ways. First, the income tax exemptions for retirement benefits increase the amounts of benefits that employees purchase. Second, the benefit allocation rules tie together the levels of retirement benefits that a retirement plan may provide to its nonhighly and highly compensated participants.

Part IV addresses the obvious fact that employees do not individually negotiate and adjust the proportion of retirement benefits that their compensation packages include (except to a limited extent when they participate in a section 401(k) plan) or the terms on which they receive retirement benefits. Instead all, or at least substantial groups, of an employer's employees receive retirement benefits that are about the same percentage of each employees' salary, and on terms that are uniform for all employees. This standardization of the levels of retirement benefits does not much change the amounts of benefits that employees receive so long as the markets for employment and retirement benefits are sufficiently thick; sorting of employees among employers that provide different levels of retirement benefits allows employees to receive the levels of retirement benefits that they are willing to pay for. The qualitative standardization of retirement benefits increases the costs, and hence the implicit prices, of the benefits.

Part V applies these insights to develop the five limitations of retirement plan law described above. A short conclusion follows.

This article advances the theory that employees control their retirement benefits. It uses a specifically defined vocabulary. ${ }^{26}$ The theory implies that when retirement plan law improves the

${ }^{25}$ See infra Part V.E.

${ }^{26}$ Below are brief definitions of terms that are more fully explained and defined at the indicated points in the text.

"Benefit allocation rules" mean the rules that govern coverage, participation, nondiscrimination in contributions or benefits, accrual, vesting, and benefits payment; these rules regulate which employees, from among all of an employer's employees, will receive benefits from a particular retirement plan. See infra text accompanying notes 170-190. 
"Employee surplus" means the excess of an employee's perceived value of retirement benefits over her implicit price for the benefits; this is an excess of perceived utility and is not directly measurable in financial terms. See infra text and Example 2 accompanying notes 98-103.

"Employer surplus" means the excess of an employee's implicit price for her retirement benefits over her employer's costs for those benefits; this surplus is measurable in financial terms. See infra Part IV.C.3 and particularly Example 3 accompanying notes 135-138.

"Highly compensated employee" means, in general terms, an employee who earns more than $\$ 90,000$ per year or owns more than $5 \%$ of the ownership interests in the employer. See I.R.C. § 414(q) (2000 \& Supp.__ 200_); see infra text accompanying notes 170-173.

"Implicit price" means the amount of salary that is forgone in exchange for retirement benefits. See infra text and Example 1 accompanying notes 62-66.

"Mandated benefits" mean retirement benefits that a plan provides to an employee to the extent that the costs of the benefits exceed the implicit price paid by the employee. See infra Part III.D.3.

"Nonhighly compensated employee" means an employee who is not included in the highly compensated employee category. See Treas. Reg. $\S 1.401(a)(4)-12$, NHCE (as amended in 1993); see infra text accompanying notes 170-173.

"Permitted disparity" means the amount by which the nondiscrimination rules permit the benefit rate of highly compensated employees to exceed the rate for nonhighly compensated employees. See infra note 186 and accompanying text.

"Productivity gains" mean the financial gains that result when sponsorship of a retirement plan causes the sponsoring employer's workforce to be more productive than it would be in the absence of the plan. See infra Part III.C.2.

"Reasonably comparable benefit" means that the rate of benefits that a plan provides to highly compensated employees does not exceed the rate provided to nonhighly compensated employees by more than the permitted disparity. See infra note 181 and accompanying text.

"Reluctant employee" means an employee who pays an implicit price for her benefits that is less than her employer's costs for the benefits. See infra Part III.D.3 and particularly Example 4 accompanying notes 194-198.

"Retirement benefits" mean the legal rights that employees receive that entitle them to receive retirement income payments at some future date. See infra text accompanying note 36.

"Willing employee" means an employee who pays an implicit price for her benefits that equals or exceeds her employer's costs for the benefits. See infra text accompanying notes 105108.

The following references are cited frequently: Joseph Bankman, The Effect of AntiDiscrimination Provisions on Rank-and-File Compensation, 72 Wash. U. L.Q. 597 (1994) [hereinafter Bankman, The Effect of Anti-Discrimination Provisions]; Joseph Bankman, Tax Policy and Retirement Income: Are Pension Plan Anti-Discrimination Provisions Desirable? 55 U. Chi. L. Rev. 790 (1988) [hereinafter Bankman, Tax Policy and Retirement Income]; Ronald G. Ehrenberg \& Robert S. Smith, Modern Labor Economics (Addison-Wesley 7th ed. 2000) [hereinafter Ehrenberg \& Smith]; Randall K. Filer, Daniel S. Hamermesh \& Albert Rees, The Economics of Work and Pay 373 (6th ed. 1996) [hereinafter Filer \& Hamermesh]; Michael J. Graetz \& Jerry L. Mashaw, True Social Security, Rethinking American Social Insurance (Yale Univ. 1999) [hereinafter Graetz \& Mashaw]; Daniel I. Halperin, Interest in Disguise: Taxing the Time Value of Money, 95 Yale L.J. 506 (1986) [hereinafter Halperin, Time Value]; Daniel I. 
quality of retirement benefits, it reduces the amounts of retirement benefits that lower-paid employees receive. It also implies that the present benefit allocation rules are largely an exercise in futility and that most proposed reforms of the rules will aggravate the very problems the reforms are intended to solve. Beyond these conclusions, the theory of employee control of retirement benefits will undoubtedly result in many other fundamental revisions of our understandings of retirement plan law.

\section{Voluntary Retirement Benefits; Mandatory Retirement Plan Law}

\section{A. Voluntary Employment and Voluntary Retirement Benefits}

The initial formation of an employment relationship is voluntary on the part of both the employer and employee. If an employer decides that it needs additional labor resources for its business, it might fill that need by seeking to hire additional employees, that is, by offering employment to individuals who appear qualified to perform the needed labor. ${ }^{27}$ When a prospective employee receives an offer of employment, she will consider the various elements of the prospective employment, including the nature of the work, working conditions and location, the employer's reputation, particularly with reference to its treatment of employees, and of course, the compensation offered by the employer. If an employer and employee reach an

Halperin, Special Tax Treatment for Employer-Based Retirement Programs: Is It "Still" Viable as a Means of Increasing Retirement Income? Should It Continue? 49 Tax. L. Rev. 1 (1993) [hereinafter Halperin, Special Tax Treatment]; Richard A. Ippolito, Pension Plans and Employee Performance (U. of Chicago Press 1997) [hereinafter Ippolito, Employee Performance]; John H. Langbein, What ERISA Means by "Equitable": The Supreme Court's Trail of Error in Russell, Mertens, and Great-West, 103 Colum. L. Rev. 1317 (2003) [hereinafter Langbein, What ERISA Means by "Equitable”]; John H. Langbein and Bruce A. Wolk, Pension and Employee Benefit Law (Foundation Press, 3d ed 2000) [hereinafter Langbein \& Wolk]; Bruce Wolk, Discrimination Rules for Qualified Retirement Plans: Good Intentions Confront Economic Reality, 70 Va. L. Rev. 419 (1984) [hereinafter Wolk, Discrimination Rules]; Deborah M. Weiss, Paternalistic Pension Policy: Psychological Evidence and Economic Theory, 58 U. Chi. L. Rev. 1275 (1991) [hereinafter Weiss].

${ }^{27}$ Alternatively, the employer might fill its need for labor by contracting with another firm or individual to supply the labor as a contractor. CITE $C f$. leased employee rules. Or the employer might transfer the activity for which additional labor was needed to another firm or individual that would supply finished goods that the employer could acquire in a simple purchase transaction. 
agreement about these elements, an employment relationship is formed. Formation of the employment relationship evidences the voluntary consent of both parties. ${ }^{28}$

Similarly, the continuation of an employment relationship reflects the continuing voluntary agreement of both the employee and employer to that relationship. Under the traditional general rule, employment is "at will," meaning that either the employee or the employer may terminate the relationship at any time without liability to the other. This traditional rule continues to accurately describe an employee's legal position, although its application to an employer has been limited by numerous statutory and judicial developments. Notwithstanding these developments it remains generally true that an employer's continuation of an employment relationship is voluntary on the part of the employer, so that it is fair to analyze that relationship as one that is voluntary. ${ }^{29}$

When an employer assesses its prospects for attracting or retaining employees, the amount of compensation $^{30}$ that it pays for particular jobs will be a central factor in its analysis. And symmetrically, when an employee considers a new job, or the continuation of existing employment, the compensation element of the employment relationship will loom large in her

28 "Voluntary" as used in this article means an action that a person takes in the absence of legal obligation. Thus, working, whether as an employee or in some other capacity, is voluntary for workers because no law requires that an individual work. Of course in a broader sense, work is probably not voluntary for many, perhaps most, workers. Given a choice between work and leisure, many workers might choose leisure, or at least more leisure than they presently enjoy. Workers work in part to earn income for the necessities of life, and in this broader sense it can be said that working is not voluntary for those who must work for a living.

${ }^{29}$ When an employer continues an employment relationship because of the risk of substantial defense costs or legal liability that might follow from firing an employee in a particular set of circumstances, the continuation of the relationship remains voluntary. The employer has decided that the expected costs associated with terminating the relationship make the continuation of the relationship the preferable alternative, an alternative that the employer voluntarily chooses. In a narrow set of circumstances, an employer may be legally obligated to continue the employment of a specific employee; in this case it could be said that continuation of the employment relationship is not voluntary on the part of the employer.

${ }^{30}$ Total compensation includes an employee's wages and salary, plus the value of any employee benefits that she receives. "Wages and salary" refers to money compensation paid to employees at approximately the same time that the employee renders services to the employer. For convenience, this article refers to this money component of compensation as "salary." "Employee benefits" are compensation paid in a form other than salary; employee benefits might include health benefits or health insurance, retirement benefits, and a myriad of other forms of in-kind compensation. 
thinking. Employees receive compensation in many forms; for almost all employees, the most significant form of compensation is the current money component, the wages or salary that the employee receives periodically and approximately contemporaneously with the performance of services. In addition to salary, compensation is paid in various forms of in-kind payments, typically referred to as employee benefits. ${ }^{31}$ Of prime importance to many employees is employer-provided health insurance. Retirement benefits are another important form of employee benefits. Employee benefits are simply compensation paid in a form other than current money. They are a current in-kind transfer to the employee of goods or services, ${ }^{32}$ or a current in-kind transfer of rights entitling the employee to receive particular goods, services, or payments from others. It is common to speak of an employee's "compensation package," which includes all the various forms of compensation that an employee receives for a particular job. Across all employers, compensation packages include an infinite variety of combinations of salary and all the various employee benefits. ${ }^{33}$

31 "Employee benefits include legally required social insurance contributions and privately provided benefits. Examples of legally required benefits are payroll-based payments employers must make to fund programs that compensate workers for unemployment (unemployment insurance), injury (workers' compensation), and retirement (old-age, survivors', disability, and health insurance-Social Security). Examples of privately provided benefits are holiday pay, vacation and sick leave, private pensions, and private health and life insurance.

"[A]mong ... large firms, ... [ $\mathrm{t}$ ] he data indicate that nonwage [employee] benefits constitute about 30 percent of total compensation, with the largest categories being pay for time not worked $(8.8 \%)$, insurance $(7.7 \%)$, legally required payments $(6.3 \%)$, and retirement $(5.3 \%)$. These nonwage benefits have been growing over time, although in the last decade their growth has slowed. In 1965, however, nonwage benefits were 18 percent of total compensation in large firms, and in the late 1940's they constituted just 13 percent of compensation." Ronald G. Ehrenberg \& Robert S. Smith, Modern Labor Economics 146-7 (7th ed. 2000). See also, John H. Langbein and Bruce A. Wolk, Pension and Employee Benefit Law 30 (Foundation Press, 3d ed 2000).

${ }^{32}$ For example, an employer might provide an employee with an automobile for personal use; the employee would receive in-kind compensation in the form of this use of the auto. When an employee receives health insurance, she receives in-kind contractual rights to receive medical services from various third-party service-providers.

${ }^{33}$ The mix of components of an employee's compensation package is controlled by the preferences of the employees who receive that package. See infra note 78 and accompanying text. 
Just as the employment relationship is voluntary on the part of both the employer and the employee, the inclusion of a retirement benefit in an employee's compensation package is voluntary. No law compels an employer to provide retirement benefits to its employees. ${ }^{34}$ And no law compels an employee to set aside, or save, any portion of her income for her own future support, support during the period after she has retired from active employment. ${ }^{35}$ An employee's compensation package will include a retirement benefit only when the employer and the employee mutually agree that the employer will provide, and the employee will accept, a portion of her compensation in the form of (legally enforceable) rights to receive retirement income payments after the employee retires. ${ }^{36}$ It is these rights to receive future retirement income payments that this article refers to as "retirement benefits." Payment of compensation in the form of retirement benefits evidences that both the employer and the employee have voluntarily agreed to pay and to receive compensation in this form.

Of course it is obviously true that employees (with very rare exceptions) do not individually negotiate whether their compensation package includes retirement benefits, or if so, the amount of the benefits. This fact is a particular illustration of a more general reality: almost all employees must either take, or leave, offers of employment as the offers are presented by an employer, and with little or no customized tailoring of the terms for any particular offeree. In other words, virtually all employment is on terms that an employer has standardized for a particular job category. However, the standardization of employment terms by job categories does not vitiate the role of employees' preferences in determining the contents of their

\footnotetext{
${ }^{34}$ See Lockheed Corp. v. Spink, 517 U.S. 882, 887 (1996) (citing Shaw v. Delta Air Lines, Inc., 463 U.S. 85, 91 (1983); accord Alessi v. Raybestos-Manhattan, Inc., 451 U.S. 504, 511 (1981). See also, Bruce Wolk, Discrimination Rules for Qualified Retirement Plans: Good Intentions Confront Economic Reality, 70 Va. L. Rev. 419, 430 (1984) ("Of course, the employer is the one who makes the decision to establish a retirement plan."). See generally Langbein \& Wolk, supra note , at 149-50; Catherine L. Fisk, Lochner Redux: The Renaissance of LaissezFaire Contract in the Federal Common Law of Employee Benefits, 56 Ohio St. L.J. 153, 157161, 170-172, n. 61 (1995).

${ }^{35}$ Nor are individuals required to contribute to any individual retirement savings programs; IRA's are voluntary. However, the Social Security Act requires retirement savings by workers. See supra note

${ }^{36}$ In order for the compensation package to include retirement benefits, an employee must agree to trade a portion of her current salary for retirement benefits. See infra note 124 and accompanying text. For convenience, the text will refer only to trade of salary for retirement benefits, even though employee benefits other than retirement benefits are also exchanged for
} 
compensation packages; employees sort themselves among jobs that offer different compensation packages, and employers tailor their packages to conform to the preferences of the employees who will receive the packages. Later we will more fully develop how sorting of employees permits them to receive compensation packages that conform to their preferences even though the packages are standardized for a group of employees. ${ }^{37}$

\section{B. Mandatory Retirement Plan Law}

Once an employer and employee have agreed that part of the employee's compensation will be paid in the form of a retirement benefit, retirement plan law sets mandatory terms for the parties' agreement. Much of retirement plan law can best be understood as law that regulates the terms of the agreement between an employer and employee about the employee's retirement benefits. ${ }^{38}$ While no law requires the parties to agree that a compensation package will include a retirement benefit, if the parties do reach that agreement, retirement plan law specifies most of the terms their agreement. ${ }^{39}$

Retirement plan law allocates to the employer the sole responsibility for implementing the parties' agreement about retirement benefits. ${ }^{40}$ Legal regulation of the retirement benefits agreement begins with ERISA's requirement that the employer must be the party that creates,

retirement benefits.

${ }^{37}$ See infra note 205 and accompanying text.

${ }^{38}$ The notable portions of retirement plan law that do not regulate the terms of the parties' agreement are the I.R.C. provisions that allow, and limit, income tax deductions and exemptions.

${ }^{39}$ There is a limited range of other fundamental choices about a retirement plan that are, in varying degrees, voluntary choices. Definition of the group of employees that will be covered by the plan has voluntary aspects, but retirement plan law includes extensive employee coverage requirements that substantially limit choices. The type of benefits that are provided is within the parties' control; an employer may provide its employees with either a defined contribution plan, or a defined benefit plan. The parties may set the level of contributions or benefits provided by the plan. However, if the plan provides any contributions or benefits for "highly compensated employees," then reasonably comparable benefits must be provided to "nonhighly compensated employees." Continuation or termination of the plan is voluntary; however, Beyond these fundamental choices, retirement plan law largely controls the structure and content of an employer-sponsored retirement plan.

${ }^{40}$ See ERISA § 3(2), 29 U.S.C. §___ (2) (2000 \& Supp. 20_) (CITE, quote definition of plan?). The employer establishes its retirement plan by formally adopting the retirement plan document by the appropriate legal action. Langbein \& Wolk, supra note, at . (what is a plan). 
operates, and maintains a "retirement plan" 41 in order to provide its employees with retirement benefits. This employer is often referred to as the "sponsoring employer"; ERISA designates it as simply the "employer" with respect to that retirement plan. ${ }^{42}$ The employer is responsible for insuring that the retirement plan conforms to the requirements of retirement plan law. The retirement plan is a forward-looking program by which an employer arranges for the payment of retirement income to an employee, prototypically after she retires from active employment. ${ }^{43}$ The employer must also create a "retirement trust" that holds the funds contributed by the employer to pay the promised future retirement benefits. ${ }^{44}$ (The plan and trust are often referred to collectively as the retirement plan. ${ }^{45}$ )

${ }^{41}$ The fact that an employer takes the formal actions necessary to establish a retirement plan creates an appearance that the employer alone determines whether its employees' compensation packages include retirement benefits. The appearance is misleading. The employer establishes a retirement plan only if the employer and a group of its employees agree that retirement benefits will be part of the employees' compensation packages.

${ }^{42}$ See ERISA § 3(5), 29 U.S.C. § 1002(5) (2000 \& Supp. 20__).

[CITE? ERISA § 3(16)(B), 29 U.S.C. § 1002(16) (2000 \& Supp. 20__) (“'[P]lan sponsor' means ... the employer in the case of an employee benefit plan established or maintained by a single employer ....").

In defining the term "plan sponsor," ERISA describes

${ }^{43}$ See generally Langbein \& Wolk, supra note, at ; Peter J. Wiedenbeck, Implementing ERISA: Of Policies and "Plans," 72 Wash. U. L.Q. 559 (1994).

${ }^{44}$ See ERISA $\S 403(a), 29$ U.S.C. $\S 1103$ (a) (2000 \& Supp. 20__). There are certain exceptions to the requirement that retirement funding be held in a trust. Id. ERISA $\S 403(\mathrm{~b}), 29$ U.S.C. $\S \_$(b). A trust is not required when retirement funds are held by a licensed insurance company, $i d$. ERISA $\S$ 403(b)(1), (2), 29 U.S.C. $\S \_\_(b)(1),(2)$, or are held by a financial institution, $i d$. ERISA $\S 403(a)(3),(5), 29$ U.S.C. $\S \_$(b)(3), (5). In the context of a retirement plan, these alternatives to a formal trust arrangement provide the same functions that would be provided by a trust. They are equivalent to trusts.

The most important functions of this retirement trust are to hold and invest all the funds that are contributed toward funding of the future retirement benefit payments. An important effect of holding retirement funding in a trust is that the funds are protected against claims of the sponsoring employer's creditors. "the assets of a plan shall never inure to the benefit of any employer ...." ERISA § 403(a), 29 U.S.C. § (a) (2000 \& Supp. 20__). the funding must ". . . be held for the exclusive purposes of providing benefits to participants in the plan ...." ERISA § 403(c)(1), 29 U.S.C. § (c)(1) (2000 \& Supp. 20__).

${ }^{45}$ For convenience, this analysis will use the term "retirement plan" to include the retirement trust, and references to the retirement plan document will include any terms that might in some cases be formally embodied in a separate retirement trust document. 
All of the terms, conditions, and provisions of the retirement plan must be embodied in written documents. ${ }^{46}$ The provisions included in the retirement plan document define the amount of retirement income that an employee will receive, and the terms and conditions on which the income will be paid. Most of these terms are required or regulated by retirement plan law. For example, retirement plan law requires that a retirement plan participant must be fully vested in her accrued retirement benefits no later than upon the participant's completion of seven years of employment with the sponsoring employer. ${ }^{47}$ In order to comply with this requirement, all retirement plans include provisions that grant participants fully vested rights within this period. There are innumerable similar mandatory terms for every retirement plan. Retirement plan law sets out exceedingly detailed and precise specifications for a plan; by controlling the form and the content of the plan, the law controls the definition of the rights that the plan confers upon an employee.

Retirement plan law requires that an employee's retirement benefit rights be legally enforceable. ERISA then confers jurisdiction on state and federal courts to enforce the rights and defines the legal remedies to which an employee is entitled. ${ }^{48}$ In order to increase the probability that these legal rights actually result in the employee's receiving payment of some retirement benefits in the future, retirement plan law requires that the sponsoring employer transfer money to the retirement trust during the years that an employee who is covered by the plan is actively

${ }^{46}$ See ERISA $\S 402(a)(1), 29$ U.S.C. $\S \_$_a)(1) (2000 \& Supp. 20__). The retirement plan document itself is often also referred to as the "retirement plan." In some contexts there may be a conflation of the connotations, with "retirement plan" being used to refer both to the employer's retirement benefits program, and to the document that describes that program.

ERISA requires that a retirement plan must be subject to amendment. See ERISA $\S$ 402(b)(3), 29 U.S.C. § 402(b)(3) (2000 \& Supp. 20__). Typically the power of amendment is held by the employer. Revision or termination of the plan may be done only prospectively, and may not reduce the accrued benefits of any participant. See ERISA $\S 204(\mathrm{~g}), 29$ U.S.C. $\S$ 1054(g) (2000 \& Supp. 200_) (subject to certain technical exceptions). Similarly, a plan amendment may not reduce a participant's vesting percentage. See ERISA $\S 203(\mathrm{c})(1)$, 29 U.S.C. $\S 1053(\mathrm{c})(1)$ (2000 \& Supp. 200__).

${ }^{47}$ See ERISA $\S 203(\mathrm{a}), 29$ U.S.C. $\S 1053$ (a) (2000 \& Supp. 200__); I.R.C. § 411(a)(2)(A) (2000 \& Supp. _ 200_). Another retirement plan term on which the law allows a range of choice is the rule governing when newly hired employees begin to participate in the plan, that is, when they begin to earn retirement benefits. A plan may not require an employee to complete more than two years of service with the employer before the employee is eligible to become a "participant" in the plan. An eligibility waiting period in excess of two years is forbidden.

${ }^{48}$ [CITE ERISA $\S 502(a)(1)(B), 29$ U.S.C. $\S \_\_(a)(1)(B)(1994 \&$ Supp. 19__) and 
employed; ${ }^{49}$ these payments are referred to as "contributions" to the plan. ${ }^{50}$ The contributions

transferred to the retirement trust are accumulated, invested, and held for distribution to a

others.

${ }^{49}$ An important effect of holding retirement funding in a trust is that the funds are protected against claims of the sponsoring employer's creditors. "the assets of a plan shall never inure to the benefit of any employer . . .." ERISA $\S 403(\mathrm{a}), 29$ U.S.C. $\S$ (a) $(2000 \&$ Supp. $20 \_$_). the funding must " . . be held for the exclusive purposes of providing benefits to participants in the plan ...." ERISA § 403(c)(1), 29 U.S.C. §___(c)(1) (2000 \& Supp. 20__).

${ }^{50}$ The amounts that must be contributed depend upon whether the plan is a "defined contribution plan" or a "defined benefit plan." The hallmark of a defined contribution plan is that the plan document specifies that the sponsoring employer will make certain contributions to the plan, the contributions will be allocated among employees participating in the plan, and the contributions will be accounted for as separate and individual accounts for each participating employee. See ERISA § 3(34), 29 U.S.C. § 1002(34) (2000 \& Supp. 20__); See generally Langbein \& Wolk, supra note, at 47-55. From the perspective of an employee, a defined contribution plan is similar to an investment account with a financial institution; the employee receives periodic statements of her account balance and the account is explicitly credited with the investment gains and losses earned by the account's investments.

A type of defined contribution plan known as a "money purchase pension plan" states that the employer will contribute a stated percentage of each participating employee's annual compensation to the retirement trust, where it is credited to a bookkeeping account referred to as the "participant's account." Another common type of defined contribution plan is the "profitsharing plan," which states that for each year that the plan is in force, an employer may contribute an amount to the retirement trust; the amount contributed is allocated among employees who are participating in the plan during that year, and credited to their participants' accounts. In a defined contribution plan, the participants' accounts are, in effect, savings accounts held for each plan participant. Each participant's account balance represents the total value of her retirement benefits at any given time; retirement plan law refers to this account balance as the participant's “accrued benefit.” See ERISA § 3(23), 29 U.S.C. $§ 1002(23)$ (2000 \& Supp. 20_). When an employer has adopted a defined contribution plan, it must contribute to the plan the amounts that the plan defines as the contributions. For example, a profit-sharing plan may provide that the employer can have the discretion to determine each year the amount that will be contributed to the plan. In this case, since profit-sharing contributions are dependent upon the employer's determination, the employer has no legal obligation to contribute to the plan until after it has made a determination of the amount that will be contributed for a given year. However, once an employer has determined the amount of profit-sharing contribution for the year, it then becomes subject to an obligation to pay that contribution before the legally established deadline. Alternatively a profit-sharing plan may provide that an employer will contribute fixed amounts to the plan, or amounts that depend upon a formula, such as a stated percentage of annual profits. See I.R.C. § 404(a)(6) (2000 \& Supp. _ 20__). Another type of defined contribution plan, the money purchase pension plan, imposes on an employer an ongoing obligation to make the contributions stated in the plan, without any further action being required. Retirement plan law obligates an employer that sponsors a defined contribution plan to pay whatever contributions the plan specifies, however they might be specified. 
participating employee, who is referred to as a "participant." ${ }^{251}$ A distribution is made to a participant when, under the terms of the retirement plan, she qualifies to receive retirement income. Retirement plan law designates this legal structure as virtually the sole and exclusive arrangement that may be used when a retirement benefit is to be included in an employee's compensation package. $^{52}$

\section{Retirement Savings and Retirement Plan Law}

As a matter of form, an employer that sponsors a retirement plan pays the contributions that must be made to a retirement plan; that is, the employer writes the checks that pay the contributions. Retirement plan law requires observance of this form; the employer is legally

In contrast, a defined benefit promises to pay each participating employee a certain pension payment beginning at some future date, typically when or after the employee actually retires from active employment. See ERISA § 3(35), 29 U.S.C. § 1002(35) (2000 \& Supp. 20__); see generally Langbein \& Wolk, supra note, at 45 . The amount of the pension payment is based on a formula which takes into account the employee's compensation earned while employed and the length of the employee's service. See generally Langbein \& Wolk, supra note , at 45, 153-56, 444-56.

When an employer has adopted a defined benefit plan, retirement plan law obligates the employer to pay contributions to the plan that will be adequate to enable the plan to pay the retirement benefits that it has promised, when, as, and if the participants reach retirement and qualify to receive actual payment of their retirement benefits. The benefits promised by the plan are, in effect, liabilities of the plan. Langbein \& Wolk, supra note, at 156. As employees earn benefits under a defined benefit plan, the employer's funding obligation accrues. The exact amount that the employer must pay each year toward its funding obligation is determined under the minimum funding standards that are a part of retirement plan law. See I.R.C. $\S 412(2000$ \& Supp. 20__). ERISA $\S \S 301-08,29$ U.S.C. $\S \S 1081-86$ (2000 \& Supp. 20__). The general aim of the minimum funding standards is to insure that, when the time arrives for payment of retirement benefits, the defined benefit plan will hold adequate assets for payment. Each defined benefit plan is required to retain a professionally qualified actuary, who annually reviews the plan's funding, determines the amount that the employer must contribute for that year, and certifies that the plan is in compliance with the minimum funding standards. Application of these rules involves the principles of actuarial science, and assumptions that an actuary makes about participants' job tenures, future salary levels, life expectancies, and the investment returns that will be earned on the plan contributions between the time of contribution and the time of benefit payment. Under the minimum funding standards, once an employer has implemented a defined benefit plan, it has a legal obligation to pay sufficient contributions to fund the defined benefits that have accrued under the plan.

${ }^{51}$ ERISA $\S 3(7), 29$ U.S.C. $§ 1002(7)$ (2000 \& Supp. 20__).

52 There are two very narrow exceptions to the requirement that an employer must utilize the funded and trusteed retirement plan structure. [CITE, ERISA exception for excess benefit plans and top hat plans.] 
liable to pay contributions to a plan, ${ }^{53}$ and the employees' income tax exclusions depend upon the employer transmitting the funds directly to the plan. ${ }^{54}$ Thus retirement plan law places the incidence of payment of contributions squarely on the employer. ${ }^{55}$ In contrast to this form, as a matter of economic substance, the cost of contributions to a retirement plan is borne by employees, either through explicit agreements to reduce salary in exchange for increased retirement contributions ${ }^{56}$ or through implicit reductions in salary (or other forms of compensation). ${ }^{57}$ The incidence of cost of retirement benefits falls on employees.

Since employees bear the economic costs of retirement benefits, when an employee's compensation package includes retirement benefits, the employee pays for her own retirement benefit by receiving less salary than she would have in absence of retirement benefits or by

${ }^{53}$ Retirement plan law requires that the sponsoring employer pay all contributions that are made to a retirement plan. When the employer sponsors a defined benefit plan, the requirement that it pay the contributions to the plan is explicit; if it fails to adequately fund the plan, ERISA imposes a lien on the employer's assets for the amount of the unpaid contributions. See ERISA § 302(f), 29 U.S.C. § 1082(f) (2000 \& Supp. 20_). In the case of a money purchase pension plan, the plan document requires a stated level of contributions, and ERISA requires that the employer to comply with the provisions of that document. See Treas. Reg. § 1.401-1(b)(1)(i) (as amended in ___), ERISA § 404(a)(1)(D), 29 U.S.C. § 1104(a)(1)(D) (2000 \& Supp. 20__). In the case of a profit-sharing plan, the requirement that the employer pay the contibutions follows from the income tax doctrine surrounding taxation of the employee's compensation. See infra note 214 and accompanying text.

${ }^{54}$ See infra note 214 and accompanying text.

${ }^{55}$ It is important to distinguish between the incidence of payment, and the incidence of cost. When an employer sponsors a retirement plan, the incidence of payment will always be on the employer; retirement plan law requires that the employer transmit payment of contributions to its retirement plan. The incidence of cost refers to the party that bears the costs of retirement plan contributions by receiving a reduced share of the economic returns that are generated from the parties' relationship. If an employer were to bear the costs of a retirement plan, those costs will affect someone who has an interest in the employer's activities; the owner of the employer might receive lower returns on her capital investment, or the employer's customers might pay higher prices for the employer's products. When employees bear the costs of a retirement plan, the employees' compensation, that is, their total share of the employer's returns is unchanged; the retirement benefits that employees receive are simply a substitute for other forms of compensation that they might have received.

${ }^{56}$ The increasingly popular section 401(k) plan provides an employee with an explicit election to receive up to $\$ 12,000$ of her compensation either as salary or as retirement benefits. See infra note 220 and accompanying text.

${ }^{57}$ Most retirement plan scholars appear to accept that proposition that in general employees bear the costs of their retirement benefits. See infra note 108 and accompanying text. 
receiving lesser amounts of other forms of employee benefits. ${ }^{58}$ In effect, the employee has agreed to trade a portion of her current salary in exchange for her current receipt of the retirement benefits. Since an employee pays for her own retirement benefit, in substance an employer-sponsored retirement plan is a structure that an employee uses to save for her own retirement. ${ }^{59}$ The funding that is accumulated for her in her employer's retirement plan can be described as her "retirement savings." ${ }^{\circ 0}$ Because retirement plan law specifies so many of the

${ }^{58}$ The description of an exchange of salary for retirement benefits is simplified. In reality, employees trade both salary and other forms of employee benefits for retirement benefits. For convenience, this article speaks of a trade of salary for retirement benefits, but this phrasing should be understood as shorthand for a trade of salary and other forms of employee benefits for retirement benefits. See infra note 108 and accompanying text for discussion of the trade-off of salary for retirement benefits.

Many retirement plans provide that an employee forfeits all or part of her retirement benefit rights if she terminates employment before the completion of five or seven years of employment. This risk of forfeiture obviously affects the value of the retirement benefit rights that the employee receives, but it does not change the fundamental conception that the employee has exchanged salary for rights, sometimes contingent, to future retirement income payments.

The most significant contingency that can affect an employee's rights to future retirement benefit payments is cessation of employment with the employer that sponsors the retirement plan. Many retirement plans provide that if an employee's employment ceases prior to the employee's completion of a stated period of service, then the employee will forfeit all or part of her retirement benefits. ERISA requires that employees' rights to retirement benefits must become nonforfeitable, that is, fully vested, when the employee completes seven years of service with the sponsoring employer. ERISA $\S 203(a)(2)(B), 29$ U.S.C. $\S \_$_a)(2)(B) (2000 \& Supp. 20__).

${ }^{59}$ This conception of an exchange of salary for (sometimes contingent) rights to future retirement income payments can be obscured by the description of a retirement benefit as a form of "deferred compensation," a term generally used to describe a program by which an employee's taxable income is deferred from one year to a later year or years. CITE $C f$. ERISA's definition of an "employee pension benefit plan" as a plan that defers income to or beyond retirement.

And it can be further obscured by a description of the cash flows associated with a retirement benefit; the employer diverts money from an employee's current salary, transfers it to a retirement trust, and the trust later pays retirement income to the employee. These alternative descriptions are accurate so far as they go. However, full understanding of the role of a retirement benefit in an employee's compensation package demands a clear focus on the current exchange of salary for the retirement benefit, which is comprised of sometimes-contingent rights to receive future retirement income payments.

60 The term "retirement savings" is used in an entirely formalistic and essentially circular sense. "Retirement savings" refers to savings that are held in an employer-sponsored retirement plan, or in one of the analogous tax-preferred programs that bear the "retirement" label. The analogous programs include the retirement plan for a self-employed personthe "simple retirement plan" or "simple retirement account," and the "individual retirement account" or 
terms and conditions that comprise an employee's retirement benefits rights, an employee's retirement savings are accumulated on terms that are largely determined by retirement plan law. ${ }^{61}$

\section{Employees Control Their Retirement Benefits}

A. Employees Trade Salary for Retirement Benefits

1. Employees' Preferences Determine Their Retirement Benefits

An employer and its employees voluntarily agree that the employees' compensation packages will include retirement benefits. The employee pays an implicit price in exchange for retirement benefits. The "implicit price" of retirement benefits is the amount of salary (or other forms of compensation) that is forgone in exchange for retirement benefits. ${ }^{62}$

"IRA." CITE.

In effect, retirement plan law identifies retirement savings as those savings that are held in a savings program that is entitled to the special income tax treatment that is accorded to retirement savings. This identification holds without reference to the owner's need, or lack of need, for support during retirement, and without reference to the ultimate purposes to which the savings are actually applied. After funds are contributed to a retirement plan, and so long as they are held in the plan, they enjoy the special tax treatment. When funds are distributed from the plan or account to the participant, the tax exemption ceases; the funds distributed are included in the participant's income. The income tax exemption for "retirement savings" can more accurately be described as an income tax exemption for funds held in a retirement plan or a retirement account.

${ }^{61}$ An example is the rule that requires that an employee's rights to her retirement savings must not be forfeitable after she has completed seven years of service with the sponsoring employer. This rule can be understood as a form of worker protective legislation; retirement benefits that remain forfeitable for an excessively long period pose such a severe risk of excessive and irreparable damage to an employee's (financial) welfare that the risk must be eliminated by an outright prohibition on lengthy periods of forfeitability. CITE. Ippolito, J. of Law and Econ. Norman Stein, ERISA and the Limits of Equity, 56 Law \& Contemp. Probs. 71, 72 n. 8 (1993) ("ERISA's creation of federal vesting standards for pension plans [citations omitted] has had a pronounced effect on the benefit contract.").

${ }^{62}$ For simplicity, we will refer to an employee trading salary for retirement benefits; in fact when an employee receives retirement benefits, the implicit price might be paid with reductions in any of the forms of compensation that she receives. $C f$. Edwad Montgomery et al., Pensions and Wages: An Hedonic Price Theory Approach, 33 Int'1 Econ. Rev. 111, 115 (No. 1, February 1992). In the actual operation of retirement plans, employees do not explicitly trade an amount of salary for retirement benefits, except for a type of retirement plan known as a "section 401(k) plan." See infra note and accompanying text. In reality, the trade of salary for 


\section{Example 1}

An Employee Pays an Implicit Price for Her Retirement Benefits

Facts: Employee $\mathrm{H}$ expects to receive total compensation of $\$ 110,000$; she plans to save $\$ 10,000 .{ }^{63} \mathrm{H}$ 's employer is indifferent between paying her $\$ 110,000$, or $\$ 100,000$ of salary and retirement benefits that cost $\$ 10,000 .^{64}$ If the parties agree that $\mathrm{H}$ would receive the second compensation package, H's employer contributes the $\$ 10,000$ to its retirement plan and $\mathrm{H}$ receives retirement benefits that cost $\$ 10,000$.

Conclusions: $\mathrm{H}$ has purchased her retirement benefits with $\$ 10,000$ of forgone salary; she has paid an implicit price of $\$ 10,000$ for her benefits.

If $\mathrm{H}$ had received $\$ 110,000$ salary, all of it would have been included in gross income for income tax purposes. ${ }^{65}$ When she receives compensation in the form of retirement benefits, she includes only the $\$ 100,000$ of salary in gross income. ${ }^{66}$

retirement benefits occurs over time and usually without the parties being aware that their arrangements have this effect. The trade off of salary and retirement benefits occurs implicitly between the parties; hence the price of retirement benefits is referred to as an implicit price.

${ }^{63}$ One very significant simplification in this model is the fact that the employee is offered an explicit choice between two compensation packages. In reality, almost all employees receive employment offers on terms that leave little or no room for negotiation. See infra note and accompanying text. If an employer offered an employee an explicit choice to receive money in lieu of retirement benefits, the employee would be taxed on all the money offered, except to the extent that the cash option met the technical requirements of a section 401(k) plan. See infra note and accompanying text.

Another simplification is the assumption that the employee regards $\$ 10,000$ of retirement savings as equal to $\$ 10,000$ of after-tax regular savings. In reality, many employees would probably prefer regular savings because there are no limits on access to, or utilization of, regular savings. In contrast, retirement savings are subject to many limitations on access. See generally Norman P. Stein \& Patricia E. Dilley, Leverage, Linkage, and Leakage: Problems with the Private Pension System and How They Should Inform the Social Security Reform Debate, 58 Wash \& Lee L. Rev. 1369 (2001); Halperin, Special Tax Treatment, supra note , at . This assumption does not change the conclusions to be drawn from the example; elimination of the assumption would require additional factors to be included in the employee's evaluation of her retirement benefits.

${ }^{64}$ The assumption that employers face budget constraints on the compensation that is offered to employees is described in more detail infra note and accompaying text.

65 "Gross income" is used in its income tax sense: income that is taxable for income tax purposes is included in a taxpayer's gross income; if there is no offsetting deduction, an amount included in gross income will be part of the taxpayer's taxable income, and be subject to income taxation. See I.R.C. $\S \S 61(a)(1)$ (2000 \& Supp. _ 200_).

${ }^{66}$ See I.R.C. § 402(a)(1) (2000 \& Supp. _ 200_); Treas. Reg. § 1.402(a)-1(a)(1)(i) (1956). 
An employee will choose to trade salary for a form of in-kind compensation when the inkind compensation provides the employee with greater value, or utility, ${ }^{67}$ than is provided by the salary that is forgone in order to pay the implicit price of the in-kind compensation. In the example, $\mathrm{H}$ chose to receive retirement benefits because she valued them more highly than an additional $\$ 10,000$ of salary. Such a choice to trade salary for retirement benefits evidences that the benefits bring some special, valuable attribute to the employee, because generally employees prefer money to in-kind compensation. Money gives each employee the complete range of choice about what she might consume or how much of her compensation she might save. ${ }^{68}$ In contrast, when compensation is paid as an in-kind benefit, the employee must utilize the benefit, or the compensation is of no value to her. ${ }^{69}$ In order for an item of in-kind compensation to provide value greater than its cost, the item must bring to the employee some additional attribute that the employee values. In-kind compensation in the form of retirement benefits brings the employee retirement savings, which to some extent are comparable to savings that the employee might accumulate in a personal savings account, but, in addition, the retirement savings enjoy reduced income taxation. The income tax preference associated with retirement benefits can make them more valuable to some employees than the implicit price that must be paid for the benefits.

In the case of retirement benefits, there are several reasons in addition to the income tax preference that explain why employees might value compensation in that form more highly than its implicit price. ${ }^{70}$ Some employees might prefer retirement benefits because they might come bundled with professional administration, professional investment management, and possibly higher rates of investment returns. ${ }^{71}$ A retirement plan might be able to provide less expensive annuity rates than are available to an individual. ${ }^{72}$ Retirement savings that are paid for with

${ }^{67}$ See infra note 81 and accompanying text.

${ }^{68}$ Ehrenberg \& Smith, supra note _, at 275. See also, Langbein \& Wolk, supra note, at 29.

${ }^{69}$ For example, an employer might provide employees with health insurance that covers the employee and her entire family. For a single employee with no children, the family coverage is of no value. Ehrenberg \& Smith, supra note _, at 278.

${ }^{70}$ See generally Langbein \& Wolk, supra note, at 30. Cf. Graetz \& Mashaw, supra note , at 103. ("Public policy has made employer-based pensions a virtual necessity for employers who have a substantial workforce.").

${ }^{71}$ See Halperin, Special Tax Treatment, supra note , at 10.

${ }^{72}$ See Halperin, Special Tax Treatment, supra note, at 11. 
money that is in effect withheld from an employee's current compensation may act as precommitment device, giving the employee greater security that she will accumulate adequate retirement savings during her working years. ${ }^{73}$ A particular employer might be able to implement a retirement plan that has an effect of enhancing the productivity of its workforce. Depending upon conditions in the labor market, some portion of this enhanced productivity may be captured by employees as increased compensation, including larger salaries than might be available from other employers for otherwise comparable jobs. ${ }^{74}$ Different attributes of retirement benefits will provide different amounts of value, or utility, to different employees. To the extent that employees value attributes of their retirement benefits more highly than the implicit price of the benefits, employees will choose retirement benefits.

Some employees will assign little or no value to retirement benefits, and they will not voluntarily trade salary for the benefits. Maybe the employee does not earn sufficient compensation to enable her to trade salary for retirement benefits. ${ }^{75}$ Or perhaps the employee is young and cannot imagine herself as older, retired person. ${ }^{76}$ If each employee could individually choose between salary and retirement benefits, different employees would trade different amounts of salary for retirement benefits; some employees would choose not to receive any retirement benefits. $^{77}$

Economists generalize this simple example in which an employee's preferences determine the components of her compensation package with an explanation known as the hedonic wage theory. ${ }^{78}$ This theory posits that workers' compensation packages include

${ }^{73}$ See Halperin, Special Tax Treatment, supra note, at 10; Weiss, supra note, at . Cass R. Sunstein, Switching the Default Rule, 77 N.Y.U. L. Rev. 106 (2002).

${ }^{74}$ See infra note 134 and accompanying text.

${ }^{75}$ See Halperin, Special Tax Treatment, supra note , at ; infra note ___ and accompanying text .

${ }^{76}$ See generally Richard A. Posner, Aging and Old Age (U. Chicago Press 1995); Weiss, supra note, at .

${ }^{77}$ We shall see that much of retirement plan law is devoted to restricting employees' choices with reference to their retirement benefits. Retirement plan law imposes extensive restrictions on the choices that employees may make about the combinations of salary and retirement benefits that they receive, and about the nature of their retirement benefit rights. See infra note ___ and accompanying text.

${ }^{78}$ See Ronald G. Ehrenberg \& Robert S. Smith, Modern Labor Economics 259 (7th ed. 2000). See infra note and accompanying text. 
differentials that compensate workers differently based upon the amenities or disamenities ${ }^{79}$ of particular jobs. For example, if two jobs were equal in all respects, except one was performed in a clean, air-conditioned office, and the other was performed in dirty and harsh conditions, the theory suggests that the second job would offer higher compensation. The difference in compensation is described as a "compensating differential;" the higher compensation for the more difficult job makes it possible for the second employer to attract workers who will perform that job. As applied to employee benefits, the theory suggests that compensation packages include compensating differentials related to the presence or absence of different forms of benefits. For example, if two jobs and the two workers performing the jobs were equal in all respects except that the compensation package for one was all salary while the compensation package for the second included salary and retirement benefits, the theory suggests that the amount of salary in the second package would be less than in the first package. The reduced amount of salary reflects a differential that compensates for the presence of the retirement benefits; the differential renders the total value of the two compensation packages equal, as they ought to be since they are paid to identical workers performing identical jobs. The hedonic wage theory suggests that different (groups of) employees receive compensation packages that include the combinations of salary and employee benefits that provide the most utility to the workers that choose particular packages. ${ }^{80}$

The hedonic wage theory is built on an assumption that workers seek to maximize their utility as opposed to their total compensation or their salary. ${ }^{81}$ The assumption that individuals seek to maximize the utility that they obtain from their activities is, of course, a hallmark of the

${ }^{79}$ See Randall K. Filer, Daniel S. Hamermesh \& Albert Rees, The Economics of Work and Pay 373 (6th ed. 1996) (“. . . jobs characterized by a specific disamenity, some aspect of the job that most workers would find unpleasant").

${ }^{80}$ See Ronald G. Ehrenberg \& Robert S. Smith, Modern Labor Economics 251-82 (7th ed. 2000); infra note and accompanying text. As applied to employee benefits, the hedonic wage theory suggests that an employee will trade wages for in-kind compensation in various combinations that maximize her utility. See also Edward Montgomery et al., Pensions and Wages: An Hedonic Price Theory Approach, 33 Int'1 Econ. Rev. 111, 125 (No. 1, February 1992) ("We find that the demand for pensions rises significantly with a worker's age and assets and the supply rises with firm size and FICA tax burden. We also find that the supply of pensions is a significant function of the implicit price of pensions.")

${ }^{81}$ See Ronald G. Ehrenberg \& Robert S. Smith, Modern Labor Economics 256-57 (7th ed. 2000). 
general economic approach to understanding human behavior. ${ }^{82}$ Economists use the term "utility" to describe a broad measure of the "good" which people seek to maximize; utility includes the ideas of happiness, pleasure, satisfaction, and fulfillment. ${ }^{83}$ The utility that an employee obtains from a given job includes the utility of the salary and employee benefits as well as the utility of doing, for example, challenging and rewarding work in a pleasant environment or the disutility of performing dangerous and unhealthy tasks in frightful conditions. Utility or disutility of geographic location, characteristics of coworkers, and dislocations of personal and family life all enter into the worker's assessment of total utility. ${ }^{84}$ An employee's individual and personal preferences determine the utility that she derives from any particular employment package, and from each element that is a part of that package. In order to maximize her utility, the employee will select the type of work that she will perform and the components of the compensation package that she will receive. ${ }^{85}$ This article assumes that employees seek to maximize their utility in their choice of jobs and compensation packages, and that the hedonic wage theory has important explanatory power in predicting how employers and employees are likely to respond to particular provisions of retirement plan law. ${ }^{86}$

${ }^{82}$ See Richard A. Posner, Economic Analysis of Law 3-4 (5th ed. 1998).

${ }^{83}$ See Richard A. Posner, Economic Analysis of Law 6, 12 (5th ed. 1998); David W. Barnes \& Lynn A. Stout, Cases and Materials on Law and Economics 3 (West 1992).

${ }^{84}$ See Ronald G. Ehrenberg \& Robert S. Smith, Modern Labor Economics 256-57 (7th ed. 2000).

${ }^{85}$ There can be essentially infinite variation among the components of compensation packages offered by different employers to different employees at different times. The assignment of utility to compensation packages is subjective with each employee, and varies widely across employees. These factors would suggest that employment relationships would present a wide range of variation among compensation packages that different employees receive.

${ }^{86}$ See Ronald G. Ehrenberg \& Robert S. Smith, Modern Labor Economics 4, 251-259 (7th ed. 2000). The assumption that individuals rationally seek to maximize utility is, of course, a fundamental assumption of economic analysis of law. At the risk of understatement, the assumption is controversial. See generally Richard A. Posner, Economic Analysis of Law 3, 1323 (5th ed. 1998). However, retirement plan law is appropriate field in which to indulge the assumption that most of the time most employees will maximize utility in most of their decisions about employment, compensation, and retirement benefits. Retirement plan law regulates part of the working portion of an individual's life. Typically a substantial purpose of working is to earn compensation; the salary portion of compensation provides the means to obtain the utility that is associated with consumption or savings, and the employee benefits provide whatever utility is associated with their various forms, including saving for retirement. To the extent that individuals undertake work in order to earn compensation, it is likely that they will be 
Hedonic wage theory suggests that an employee's compensation package will include retirement benefits when the presence of those benefits increases the utility of the package to the employee. Assume that an employer faces a compensation budget constraint; that is, the employer has a given amount that it can spend on compensation for the employee. ${ }^{87}$ Given a fixed budget, the employer will construct a compensation package that will provide maximum utility to the employee. With reference to the facts of Example 1, assume that the employer and employee $H$ have agreed that $H$ will receive $\$ 100,000$ of salary, and that $\$ 10,000$ of the compensation budget remains to be allocated. If $\mathrm{H}$ assigns greater utility to an amount of retirement benefits that the employer can purchase for $\$ 10,000$ (or for less than $\$ 10,000$ ), than she does to $\$ 10,000$ paid as additional salary, then the utility of the compensation package can be increased by including that amount of retirement benefits in the compensation package. ${ }^{88}$ As between a marginal $\$ 10,000$ of salary, or an amount of retirement benefits, the employee prefers the retirement benefits. In theory, the process of substitution of retirement benefits for salary is reiterated until the utility provided by the last dollar of retirement benefits equals the utility provided by the last dollar of salary. ${ }^{89}$ In this way, the employee's acceptance of retirement benefits evidences her preference for those benefits.

particularly focused on maximizing utility in this context.

Fundamentally, retirement plan law regulates the components of employees' compensation packages, and it attempts to adjust the relative proportions of these components. Changes in the components of a compensation package necessarily change the utility that it provides to an employee, and it is likely that over time most employees will respond in some manner to adjustments in their compensation packages. The assumption of rational utility maximization and the predictions of the hedonic wage theory may provide the best predictions of employee responses. However, employees may respond differently than this theory would predict. If these unpredicted responses can be systematically explained, then other theories may supplant the hedonic wage approach. The growing field of behavioral law and economics is attempting to identify and explain employee behavior that seems inconsistent with rational utility maximization. See generally Cass R. Sunstein, ed, Behavioral Law and Economics (Cambridge U. Press 2000). See infra note and accompanying text.

${ }^{87}$ See infra note ___ and accompanying text.

${ }^{88}$ Note that the comparison of utility is at the margin. The employee who expects to receive $\$ 100,000$ of salary assigns greater utility to retirement benefits than to an additional $\$ 10,000$ of salary. A different employee for whom the compensation budget was $\$ 20,000$ might prefer to receive the entire $\$ 20,000$ as salary. In other words, the second employee's 20,000 th dollar yielded greater utility than her first dollar of retirement benefits would yield.

${ }^{89}$ See Lawrence H. Summers, Some Simple Economics of Mandated Benefits, 79 Am. Econ. Rev. (Papers \& Proceedings) May 1989, 177 at 178. 


\section{Employees' Preferences Control Their Employers' Choices}

In order for employees to receive compensation packages that maximize the utility of the compensation packages to the employees, employers must provide packages that include the components that the employees value most highly. There are two processes at work in labor markets that cause employers to provide employees with the forms of compensation that employees prefer: the compensation package design process and the employee job selection process. These processes cause the employees' preferences to control the make-up of their compensation packages. Superficial observation might lead one to believe that an employer determines the components of its employees' compensation packages; an employer is the party that has immediate and direct control over the design of the packages. However, an employer uses this control over employees' compensation packages to provide its employees with the forms of compensation that the employees prefer.

Employees' preferences control the choices that an employer makes as it designs compensation packages for its employees. In designing compensation packages, employers will respond to the fact that some employees, or potential employees, prefer various forms of employee benefits to salary. An employer will endeavor to allocate its compensation budget so that an employee's compensation package delivers the maximum possible utility to the employee. In Example 1, the two packages, $\$ 110,000$ of salary or $\$ 100,000$ of salary and retirement benefits that cost $\$ 10,000$, involve equal costs for the employer. Since the employee, $\mathrm{H}$, chose the package that included retirement benefits, it is clear that retirement benefits provide her with more utility than an additional $\$ 10,000$ of salary would have provided; for example, $\mathrm{H}$ might value the retirement benefits that she received as the equivalent of an additional $\$ 14,300$ of salary. ${ }^{90}$ In this case, $\mathrm{H}$ would be receiving a compensation package that she values at $\$ 114,300$ even though it costs her employer only $\$ 110,000$. By providing potential and current employees with compensation that employees perceive as more valuable than other alternatives, the

${ }^{90}$ Exactly how different employees assign utility and value to retirement benefits is not essential to the analysis. The point is that some employees prefer some retirement benefits to salary some of the time. This example in which the employee values her retirement benefits at $\$ 14,300$ is developed further below; in the example, the employee prefers retirement benefits to this extent because they are exempt from current income taxation. See infra note and accompanying text. 
employer is able to attract and retain higher quality employees. ${ }^{91}$ The employer has a clear incentive to provide employees who prefer retirement benefits to salary with a compensation package that includes those benefits. ${ }^{92}$ There is empirical evidence that compensation packages are designed by employers in order to satisfy their employees' preferences.

"Among manufacturing workers who have the same total compensation, but different tax rates because of nonlabor income or their spouse's earnings, those facing higher tax rates are more likely to work for employers who spend more for pension and health insurance benefits (and, therefore, less on wages). In addition, employee benefits are more extensive and employees pay less for them in states

${ }^{91}$ Employers are for-profit business firms, and they generally seek to maximize profit. In addition, if an employer operates in a competitive market, and if it fails to spend its compensation budget efficiently, it will tend to employ less productive workers, and it will incur higher operational costs. In general employers that face higher cost structures will loose customers to other, more efficient firms, and ultimately they will cease to exist. Thus, over time a competitive market eliminates employers that do not spend their compensation budgets efficiently, leaving employers who operate consistently with the assumption of maximizing the utility that compensation packages provide to employees.

92 "Thus, employers will tailor their compensation packages to suit the preferences of the workers they are trying to attract. If their employees tend to be young or poor, for example, their compensation packages may be heavily weighted toward wages and include relatively little in the way of pensions and insurance. Alternatively if they are trying to attract people in an area where family incomes are high and hence employee benefits offer a relatively large tax savings, firms may offer packages in which benefits constitute a large proportion of the total."

Ronald G. Ehrenberg \& Robert S. Smith, Modern Labor Economics 280 (7th ed. 2000). Compare Professor Bankman's interpretation:

"For example, since tax-favored pension benefits are more valuable to highly compensated employees, firms with a large proportion of highly compensated employees are apt to build the compensation mix desired by those employees, and to offer a high level of pension benefits. Other companies are apt to fashion a compensation mix which enables them to more effectively compete for rank-and-file workers."

Bankman, Tax Policy and Retirement Income, supra note, at . CITE. Jeff D. Opdyke, Companies Upgrade Retirement Plans, Wall St. J., July 25, 2002, at D1.

At D3. "Ford Motor has also scaled back its 401(k) in an effort to make the plan easier for employees to navigate. Because the options were so numerous, a Ford spokesman says worker feedback revealed that employees were 'Overwhelmed' and 'that they didn't have a good idea of what they were doing.' Ford has scaled back the number of choices in its plan. The spokesman says, 'We felt we weren't doing them a good job of offering them the right options."' 
where high state tax rates increase the cost advantage of employer-provided benefits." 93

Surveys that investigate the choices that employers make about providing their employees with retirement benefits confirm the importance of employees' preferences. $^{94}$ In designing compensation packages, employers will provide employees with the forms of compensation that the employees prefer.

In the employee job selection process, a prospective employee selects among alternative jobs, and the associated compensation packages, and chooses the alternative that offers the employee the greatest utility. ${ }^{95}$ As employees select jobs, the job selection process becomes a self-sorting process; employees who prefer salary to retirement benefits will generally tend to select employment with employers that do not offer retirement benefits, while employees who prefer the benefits will select jobs with employers that sponsor a retirement plan. ${ }^{96}$ As this process is repeated by many workers over time, an employer's employees will tend to be composed of individuals who have similar preferences for forms of compensation. The employee self-sorting process feeds back into the decisions that employers make as they design compensation packages. ${ }^{97}$ As an employer's group of employees becomes increasingly

${ }^{93}$ See Randall K. Filer, Daniel S. Hamermesh \& Albert Rees, The Economics of Work and Pay 405 (6th ed. 1996).

94 The Employee Benefits Research Institute annually conducts the Small Employer Retirement Survey about retirement plan sponsorship among small employers, those with 5 to 100 full-time workers. The survey asks employers to identify the most important reason for offering a retirement plan; the most frequent responses are a "competitive advantage in employee recruitment and retention" (30\%), and "positive effect on employee attitude and performance" $(23 \%)$. The most frequent responses for the most important reason for not offering a plan are "employees prefer wages and/or other benefits" (22\%), and "large portion of employees are seasonal, part-time, or high turnover" (15\%). EBRI research and education team, EBRI Research Highlights: Retirement Benefits (Employee Benefit Research Institute Special Report SR-42, Issue Brief No. 258, June 2003). These data are consistent with the proposition that employee preferences determine whether they receive retirement benefits.

95 See Richard A. Ippolito, Pension Plans and Employee Performance (U. of Chicago Press 1997).

${ }^{96}$ Cf. Halperin, Special Tax Treatment, supra note, at 17-18 ("Some employees would still prefer $\$ 100$ of current compensation to [retirement benefits]. . In these circumstances, such an employee, assuming she has other alternatives, will not accept a job where part of the wage package is used to provide [retirement benefits].")

${ }^{97}$ See Randall K. Filer, Daniel S. Hamermesh \& Albert Rees, The Economics of Work and Pay 406 (6th ed. 1996) ("By careful design of its fringe benefit package, an employer can exert a great deal of influence over the characteristics of its work force.") 
homogeneous with reference to their compensation preferences, the employer will receive clearer and stronger signals about the forms of compensation to include in its compensation packages. The employee job selection process allows employees to satisfy their preferences and it reinforces the compensation package design process.

\section{Employee Surplus and Willing Employees}

When an employee chooses to receive retirement benefits, additional value is created because the employee receives greater utility from a compensation package that includes retirement benefits than she would have received if her compensation package included only salary. This excess of an employee's perceived value of retirement benefits over her implicit

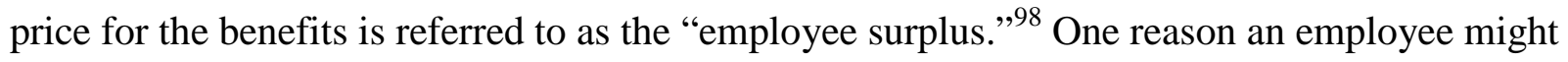
value retirement benefits more highly than salary is because retirement benefits are excluded from the employee's current taxable income.

\section{Example 2}

The Income Tax Exemption for Retirement Benefits Can Create Employee Surplus

Facts: $\mathrm{H}$ pays an implicit price of $\$ 10,000$ for retirement benefits that cost her employer $\$ 10,000$. $\mathrm{H}$ receives a salary of $\$ 100,000$. Any compensation that $\mathrm{H}$ might receive in excess of $\$ 100,000$ would be subject to a $30 \%$ income tax rate; thus, in order to accumulate $\$ 10,000$ of regular savings, $\mathrm{H}$ would have to receive additional salary of about $\$ 14,300 .{ }^{99}$

$\mathrm{H}$ regards the retirement benefits that cost her employer $\$ 10,000$ as equivalent to $\$ 10,000$ of regular savings.

Conclusions: $\mathrm{H}$ might value her retirement benefits (that cost $\$ 10,000$ ) as being equivalent to $\$ 14,300$ of additional (pretax) salary. $\mathrm{H}$ might assign a value of $\$ 14,300$ to her retirement benefits.

When $\mathrm{H}$ receives retirement benefits that cost her employer $\$ 10,000$, she receives employee surplus of $\$ 4300$.

${ }^{98}$ The concept of employee surplus is entirely theoretical. It is not possible to directly observe or measure employee surplus. Cf. Joseph Bankman, The Effect of Anti-Discrimination Provisions, supra note , at 604 (“. . . employee surplus, that portion of the perceived compensation above the reservation price."); Wolk, Discrimnation Rules , supra note , at 431-2 (arguing that a high tax-bracket employee would value a retirement plan contribution at an amount greater than the employer's cost).

${ }^{99} \$ 14,300$ is the amount of taxable salary that she would have to earn in order to save $\$ 10,000$ on an after-tax basis. Taxable salary of $\$ 14,300$ taxed at a $30 \%$ rate yields an income tax liability of about $\$ 4300$, which leaves $\$ 10,000$ for after-tax savings. 
(In this example, $\mathrm{H}$ uses a method of valuation that is not theoretically correct, but this is not important. ${ }^{100}$ What is important is that $\mathrm{H}$ assigns a value to her retirement benefits that is different from the implicit price, not how she determines that value.)

In addition to employee surplus that arises from the income tax preference for retirement benefits, surplus can arise from the other attributes associated with retirement benefits such as professional administration and investment management. ${ }^{101}$ An employee may think of the surplus value of her retirement benefits in dollar terms or she may not; it does not matter. Different employees will assign different values to their retirement savings. Some might value retirement benefits even more highly than their tax savings would imply, perhaps because they particularly appreciate that retirement savings may come to them bundled with professional administration and investment management. ${ }^{102}$ Other employees might assign minimal value, or even no value, to retirement benefits. ${ }^{103}$ The valuation of retirement benefits that employees

100 The fact that tax sophisticates would disagree with the methodology that this employee utilized to value her compensation package is not important. The important omission from the employee's valuation method is the reduction of her current tax savings by the present value of the future income tax that she will pay on the distribution of the total of the $\$ 10,000$ plus the (tax-exempt) investment earnings that have accumulated. See generally Halperin, Time Value, supra note, at .

Assuming that the employee could earn the same rates of return on personal savings as the retirement plan earns, that there were no changes in her tax rate, and that the retirement plan paid income tax on its investment income at the same rate that the participant pays, the present value of the tax liability on the distribution would equal the $\$ 4300$ of tax avoided with the contribution to the retirement plan. Halperin, Time Value, supra note, at . It is this equivalence that proves that the net benefit of retirement savings is the income tax exemption for the retirement plan's income.

If the employee applied a more sophisticated valuation model, she would assign a different and perhaps far lower value to the retirement benefit that she earned. However, the example is useful as an illustration of one method that ordinary employers and employees might use to value retirement benefits. In fact, the valuation of a retirement benefit that an employee earns in any given year is subject to myriad factors. The simplistic method illustrated may be as good an approximation as others. CITE See infra note

${ }_{101}^{10}$ See supra note ___ and accompanying text.

102 See generally Langbein \& Wolk, supra note , at . Another employee might distrust her own discipline in saving for retirement, and therefore prefer that part of her income placed beyond her immediate grasp. Deborah M. Weiss, Paternalistic Pension Policy: Psychological Evidence and Economic Theory, 58 U. Chi. L. Rev. 1275 (1991).

${ }^{103}$ See infra note ___ and accompanying text. 
receive is subjective with each employee. The income tax preference should increase the value of retirement benefits for every employee; however, it does not cause retirement benefits to have a value to every employee that is in excess of the implicit price that the employee might have to pay for the benefits. The income tax preference does cause some employees to choose retirement benefits instead of other forms of compensation.

An employee will choose to receive retirement benefits instead of salary when the retirement benefits provide employee surplus, that is, when the utility provided by the retirement benefits has a value that exceeds the implicit price of the benefits. The hedonic wage model suggests that an employee will continue to trade salary for retirement benefits up to the level at which the marginal utility of the last unit of retirement benefits purchased by a dollar equals the utility of the last dollar of salary. ${ }^{104} \mathrm{Up}$ to this point, the employee voluntarily trades salary for retirement benefits. From the employer's side, it will provide an employee with retirement benefits so long as the employee pays an implicit price that at least equals the employer's costs of her retirement benefits. ${ }^{105}$

We can relate the employee's preference for retirement benefits and the employer's incentive to satisfy that preference with the concept of the "willing employee"; a willing employee pays an implicit price for her retirement benefits that equals or exceeds the costs of benefits to the employer. (Below we will develop the complementary concept of the reluctant employee, the employee who is unwilling to pay an implicit price sufficient to cover the costs of her retirement benefits. ${ }^{106}$ ) The employer of a willing employee provides her with retirement benefits because the implicit price paid by the willing employee covers the costs that the employer pays for the retirement benefits. In the example above, $\mathrm{H}$ is a willing employee because the implicit price that she pays, $\$ 10,000$, equals the employer's cost of the benefits, $\$ 10,000$. In a moment we will consider the more important case in which a willing employee pays an implicit price that is greater than her employer's costs of the benefits; for example, an

${ }^{104}$ See supra note and accompanying text.

105 This assumes that an employer is indifferent between applying its compensation budget to the purchase of retirement benefits, or to paying it as salary. The employer will continue to purchase additional retirement benefits for the employee so long as the employee is willing to pay an implicit price that at least equals the employer's costs because by doing so, it is delivering additional utility to the employee. So long as the employee is voluntarily paying for the benefits, the employee is demonstrating that she prefers retirement benefits to salary. 
employee might accept a salary reduction of $\$ 15,000$ even though the employer spends only $\$ 10,000$ on retirement benefits for her. ${ }^{107}$

To summarize, a willing employee receives retirement benefits because she pays an implicit price that is at least sufficient to cover her employer's costs of those benefits. And the employer provides those benefits to her, because the benefits increase the utility provided by the employer's compensation package. The willing employee's preferences determine the amount of retirement benefits that she receives (aside from the effects of retirement plan law). This is the second major premise in our argument that employees largely receive just the retirement benefits that they are willing to pay for.

\section{B. Employees Bear the Costs of Retirement Benefits}

\section{Compensating Differentials}

An assumption of the hedonic wage theory is that an employer has a fixed budget to spend for the total compensation of employees; the theory explains how that budget is applied in order to maximize the utility that employees derive from their compensation packages. ${ }^{108}$ Given

\footnotetext{
${ }^{106}$ See infra note

107 See infra note and accompanying text.

108 "Our theory suggests that employers probably will not--and in a
} competitive market cannot--absorb the added pension costs. Those firms for which pension costs are increased will have to hold the line on future wage increases to remain competitive in the product market, and over time the wages they pay will fall below the level that would have held had it not been for the pension reform legislation [imposing mandated vesting]. Alternatively, firms whose expected pension costs rise because of vesting may choose to offset this rise with a reduction in promised pension benefits. In either case, theory suggests that workers bear the added costs, as well as reap the benefits, of the mandated change in vesting."

Ronald G. Ehrenberg \& Robert S. Smith, Modern Labor Economics 279 (6th ed. 1997). The assumption that an employer faces a budget constraint on the compensation that it can pay to employees will describe employers that operate in a competitive product or service market. If an employer in a competitive market pays employees too much, the employer's goods or services will be too expensive, consumers will choose alternatives, the employer will fail, and the employees will be without work.

Conversely, an employer must provide employees with compensation packages that are competitive in the labor market; it cannot pay employees "too little." In other words, the employer must offer a compensation package that is as valuable to its employees, and to prospective employees, as the packages offered by other employers seeking to employ similar 
this fixed budget, when an employee chooses to receive one form of employee benefits, she necessarily must accept some reduction in some other component of the compensation package; these reductions are called "compensating differentials." As applied to retirement benefits, the theory suggests that if employees receive retirement benefits, then they will accept a compensating differential in the form of a reduction in salary or in other employee benefits. In our example above, the reduction in the employee's salary from $\$ 110,000$ to $\$ 100,000$ is the compensating differential for her receipt of retirement benefits. ${ }^{109}$ The presence of the compensating differential reflects the fact that the cost of retirement benefits has been shifted to the employee.

In the operation of real world employment markets, the shifting of costs of retirement benefits to employees does not occur instantaneously, nor for each employee individually, (except when employees explicitly trade salary for retirement benefits under the type of retirement plan known as a section $401(\mathrm{k})$ plan $^{110}$ ). Instead, over periods of time, and as

workers for similar (strictly, identical) jobs. If an employer failed to offer competitive compensation, it would fail to attract sufficient numbers of workers, or it would attract lower quality workers. The labor market determines the size and shape of an employer's compensation package.

${ }^{109}$ The example of an explicit and instantaneous trade-off of wages for retirement benefits is highly stylized. Important simplifying elements of the example are that the trade-off is fully completed in one period, that the employer's compensation budget is inflexible in that period, and that the trade-off occurs for a single employee individually. Reality is far more complex but the example accurately captures the operation of the trade-off.

The simplified example completes the wage-retirement benefit trade-off in one period. In reality, when an employer increases retirement benefits, and concomitantly their cost, then the rates of future wage increases are moderated. Employees pay for an increase of retirement benefits by receiving lower wages in the future. Interestingly, the $\S 401(\mathrm{k})$ plan, a form of retirement plan that has been widely and increasingly adopted during the past 20 years, is distinguished by the fact that it explicitly permits or requires employees to pay for their retirement benefits by reducing their wages, and it allows this trade-off to be adjusted annually or more frequently.

The simplification limits an employer's cost to a stated budget amount. As implied by the fact that shifting of the cost of retirement benefits occurs over time, in reality an increase in retirement benefits increases an employer's total compensation cost at the time the benefit increase is implemented. However, it is important to remember that over several years, the budget constraint will limit total compensation cost. It is unrealistic to believe that if an employee were earning wages of $\$ 100$, and the employer were required by law to provide that employee with retirement benefits that cost $\$ 10$, that the employer could afford total compensation cost of $\$ 110$ over the long run. See infra note 130 and accompanying text.

${ }^{110}$ See infra note 220 and accompanying text. 
employees sort themselves among different employers that offer different compensation packages, each employee accepts job offers that provide her with the greatest utility. Of course each alternative job and the associated compensation package offer an essentially fixed bundle of separate elements, and presumably few employees receive their first preference for each element of the total job package; employees necessarily must compare the total utility for different complete packages. Nonetheless, employers constantly adjust the job and compensation packages that they offer, and employment packages evolve to provide employees with the greatest utility that each employer can offer within its budget constraint. As a compensation package is changed over time to include, for example, more retirement benefits, compensating differentials develop in other components of the package that in effect shift the costs of the retirement benefits to the employees. When an employer has existing employment relationships with a group of employees, compensating differentials develop in employees' compensation packages over time. For example, if employees receive increased retirement benefits, their future wage increases will be less than they might have received in the absence of the increased benefits. ${ }^{111}$ These longer term, evolutionary processes result in the compensating differentials that are found in compensation packages.

The compensating differentials reflect the fact that the costs of various employee benefits have been shifted to employees. ${ }^{112}$ Thus, the existence of such compensating differentials is central to this analysis, and it has enormous implications for retirement plan law. It is vital to carefully assess the degree to which cost shifting actually occurs in the real world. Economists seek to find evidence that when all else is equal among employees, those with retirement benefits

${ }^{111}$ A reduction in wage compensation resulting from the addition of mandated retirement benefits would not occur contemporaneously with employees' accrual of the mandated benefits. The forgone wage compensation results in future periods by means of smaller increases in wages than might have occurred if no retirement benefits were provided. In addition, there is not necessarily a perfect dollar correspondence between the costs of retirement benefits and the forgone future wages. And the costs of increased retirement benefits might be borne by employees not only through a reduction in the employees' wage compensation, but also through reductions in forms of in-kind compensation other than retirement benefits. However, the theory posits that there is a significant relationship between the provision of retirement benefits, and reductions in other forms of compensation.

112 This assumes that the amount of tax subsidy to a retirement plan is held constant. Of course to the extent that the costs of retirement benefits can be shifted to the government, then both employers and employees can gain from an increase in the amount of retirement benefits paid to employees. 
receive lesser amounts of other forms of compensation. Given the myriad factors that account for differences in compensation among employees, and the practically infinite range of variation of components within compensation packages, isolating a relationship between retirement benefits and the other components of compensation is extremely difficult. ${ }^{113}$

Empirical studies that test the theory of compensating wage differentials for the costs of retirement benefits have yielded mixed outcomes, although improvements in statistical methods and data appear to be generating more robust results that tend to confirm the theory. ${ }^{114}$ One summary of the literature illustrates the wide range of conclusions that the studies suggest. ${ }^{115}$ One of the more recent studies finds some evidence of a wage-retirement benefits trade-off, but there are limitations to the conclusions that can be drawn. ${ }^{116}$ Another recent study reaches a strong conclusion that the costs of retirement benefits are shifted to employees. ${ }^{117}$

113 "Actually observing the trade-off between wages and employee benefits is not easy. Because firms that pay high wages usually also offer very good benefits packages, it often appears to the casual observer that wages and employee benefits are positively related. Casual observation in this case is misleading, however, because it does not allow for the influences of other factors, such as the demands of the job and the quality of workers involved, that influence total compensation. The other factors are most conveniently controlled for statistically, and the few statistical studies on this subject tend to support the prediction of a negative relationship between wages and benefits." Ehrenberg \& Smith, supra note, at 280.

${ }^{114}$ See generally Ronald G. Ehrenberg \& Robert S. Smith, Modern Labor Economics 280-82 (7th ed. 2000) (studies support the negative relationship between wages and benefits). Randall K. Filer, Daniel S. Hamermesh \& Albert Rees, The Economics of Work and Pay 402-08, and at 407 (6th ed. 1996) ("Among otherwise identical workers in the private sector in 1969, earnings were roughly $\$ 1$ lower for each $\$ 1$ increase in employer's costs of pensions.")

CITE. $C f$. Randall K. Filer, Daniel S. Hamermesh \& Albert Rees, The Economics of Work and Pay 173 (6th ed. 1996) ("There is evidence that both fringe benefits and the amount of on-the-job training are reduced by increases in the minimum wage.")

${ }^{115}$ Morley Gunderson et al., Wage-Pension Trade-offs in Collective Agreements, 46 Industrial and Labor Relations Review 146, at 148 (no. 1, October 1992).

${ }^{116}$ Morley Gunderson et al., Wage-Pension Trade-offs in Collective Agreements, 46 Industrial and Labor Relations Review 146, at 158 (no. 1, October 1992).

117 "[W]e find a large and significant compensating differential between the expected present values of wages and pensions for a random sample of workers with defined benefit pensions. The magnitude of the estimated differential implies a one-for-one pension-wage tradeoff over a worker's lifetime. ... Our spot market estimates produce a compensating differential of less than a quarter the size of the lifetime tradeoff. Thus, we find strong support for a 
Economists have also studied the incidence of cost of employer-provided health insurance benefits. ${ }^{118}$ These studies may support the conclusion that employees bear the costs of their retirement savings since there are important similarities between health insurance and retirement benefits. Both forms of benefit are included in employees' compensation packages voluntarily, in that both employer and employee must agree that compensation will be paid in this form. And both forms of benefits protect an employee against a future contingency, although the risks of large medical expenses or denial of medical care may be much more real and immediate for employees than the risks of impoverishment during one's old age. (The risks protected against by these two forms of employee benefits are relevant because they affect the utility that employees assign to the benefits, and hence the employees' willingness to accept employment that includes the benefit as part of the compensation package.) Until recently, economists have had difficulty in empirically confirming the wage-health insurance trade-off. ${ }^{119}$ However, a recent study offers strong and clear evidence that the cost of employer-provided health insurance is shifted to the employee who benefits from the insurance. ${ }^{120}$ Given the similarities between health insurance and retirement benefits, confirmation of the compensating differential theory in the health insurance case lends support to the conclusion that the costs of retirement benefits are shifted.

The incidence of cost of other types of employee benefits has also been investigated. A study found that a substantial portion of the cost of legally required workers' compensation insurance is shifted to workers through reduced wages. ${ }^{121}$ A well-known study concluded that

substantial pension-wage tradeoff that suggests that the underlying structure of the labor market is one of long-term implicit contracts."

Edward Montgomery et al., Pensions and Wages: An Hedonic Price Theory Approach, 33 Int'1 Econ. Rev. 111, at 125 (No. 1, February 1992).

118 "Most economists believe that employers do not pay directly for increases in health insurance costs. Instead, those costs are passed on to workers in lower wages, often in the form of lower increases in wages than employees would otherwise receive." Steven L. Willborn et al., Employment Law Cases and Materials 926 (2d ed. Lexis 1998).

${ }^{119}$ Craig A. Olson, Do Workers Accept Lower Wages in Exchange for Health Benefits? 20 J. Lab. Econ. S91, at S92 (no. 2, part 2, 2002).

${ }^{120}$ Craig A. Olson, Do Workers Accept Lower Wages in Exchange for Health Benefits?

20 J. Lab. Econ. S91, at S113 (no. 2, part 2, 2002).

${ }^{121}$ Jonathan Gruber and Alan B. Krueger, The Incidence of Mandated EmployerProvided Insurance: Lessons from Workers' Compensation Insurance, 5 Tax Policy and the 
virtually all of the costs of legally mandated health insurance benefits for maternity expenses were shifted to the employees who benefited from the coverage. ${ }^{122}$ There is a general consensus in the literature that employees bear the costs of Social Security payroll taxes including the portion of the tax that is formally imposed on employers. ${ }^{123}$ The support found for compensating differentials for various forms of employee benefits suggests that there are likely to similar differentials for the costs of retirement benefits.

There seems to be a fairly broad consensus among retirement plan scholars that the economic studies provide a reasonable basis for concluding that the costs of retirement savings are shifted to employees. ${ }^{124}$ There is also anecdotal support for the trade-off between wages and retirement benefits. A study of the failure of the Studebaker-Packard Corporation and its

\section{Economy 111 (1991). \\ ${ }^{122}$ Jonathan Gruber, The Incidence of Mandated Maternity Benefits, 84 Am. Econ. Rev. 622, 623 (No. 3, June 1994). \\ CITE. Does Christine Jolls, Accommodation Mandates, 53 Stan. L. Rev. 223, (2000). say this? \\ ${ }^{123}$ See Lawrence Zelenak, The Income Tax and the Costs of Earning a Living, 56 Tax L.} Rev. 39, 52 (Fall 2002) ([T]here is a consensus among economists that workers bear virtually the entire burden of the Social Security tax); Harvey S. Rosen, Public Finance 266 (6 ${ }^{\text {th }}$ ed. 2002 McGraw Hill Irwin) ("At least in the short run, labor probably bears most of the payroll tax, despite the congressional attempt to split the burden evenly [between the employer and employee].); Daniel Shaviro, Making Sense of Social Security Reform 10 (2000) ("Economists generally agree that the distinction in who pays which portion of the payroll tax has no effect on economic incidence, and that at least in the short run the entire tax is largely borne by workers."); Filer \& Hamermesh, supra note 26, at 226 (summarizing studies that find that employees bear most of the payroll tax and concluding that designation of a nominal payee of the tax has no effect on its incidence, which is determined by the elasticities of labor supply and demand).

CITE. Ehrenberg \& Smith, Modern Labor Economics states that although the evidence is somewhat ambiguous, most of a payroll tax is eventually shifted to wages, probably over periods on the order of 5 to 10 years. FH\&R references a study that showed that $1 / 2$ of a tax increase was shifted within one year.

${ }^{124}$ See Langbein \& Wolk, supra note 26, at 29 ("Employees pay for pensions and other fringe benefits in reduced cash compensation."); Halperin, Special Tax Treatment, supra note , at 14 ("The employer, on the other hand, would expect to decrease current wages in the amount of any contributions except to the extent [it derives non-tax benefits from retirement contributions]."); $C f$. Howell v. U.S., 775 F.2d 887 (7th Cir. 1985). Retirement benefits are an element of compensation. See Robert L. Clark \& Ann A. McDermed, The Choice of Pension Plans in a Changing Regulatory Environment at 1 (American Enterprise Institute 1990) ("The principal objective of this study is to assess the extent of the change in pension coverage by plan type since 1974, and to explain the observed shift toward defined contribution plans.") 
retirement plan, which loomed large in the origins of ERISA, found that there had been a clear understanding on the part of management and labor that increased contributions to the retirement plan would have implied smaller future wage increases. ${ }^{125}$ A legal scholar considering an analogous issue of changing the default rule for employment termination reviewed the literature on the incidence of costs of mandatory employment terms and concluded that some, perhaps a substantial, portion of the costs would likely be borne by employees. ${ }^{126}$ There are good grounds on which to conclude that employees bear the incidence of cost of their retirement benefits.

\section{Employees, Customers, and Owners}

When we consider whether employees bear the costs of their retirement benefits, we should ask who might bear these costs if the employees do not? The incidence of payment of costs is on the employer; if costs of retirement benefits rise, the employer must initially write the checks that pay the costs. But this tells us nothing about who will bear the incidence of the cost over time. An employer is nothing more than a person who coordinates the interests of three constituencies: employees, owners (who supply capital), ${ }^{127}$ and customers. The employer brings

125 See James A. Wooten, “The Most Glorious Story of Failure in the Business": The Studebaker-Packard Corporation and The Origins of ERISA, 49 Buff. L. Rev. 683, 685, 692 (2001).

${ }^{126}$ See Cass R. Sunstein, Switching the Default Rule, 77 N.Y.U. L. Rev. 106, 126 (2002). In the following excerpt, Professor Sunstein uses the term "redistribution" to refer to a transfer of wealth to employees as a group as a result of a change in the employment termination default rule. The analysis discusses changing the default employment rule to a rule that grants employees a waivable right to be discharged from employment only if the employer has "good cause" for the discharge.

"From the standpoint of redistribution, the question for labor and employment law is the incidence of the cost, faced only initially by employers, of the switched entitlement. There is a growing body of work, both theoretical and empirical, on the distributional consequence of mandatory terms, and the issues are not altogether different for switched default rules. A grossly simplified overview: In general, mandatory terms are most unlikely to produce significant distributional gains. ... [T] There is a significant risk that any redistributive gain will be nullified, at least in part, through readjustment of the wage package. On plausible assumptions, workers will lose, in wages, some or much of what they gain as a result of the switched entitlement." Id at 126.

${ }^{127}$ In addition to supplying capital to the employer, owners hold the residual claims to the employer's assets, and have rights to control, to a greater or lesser degree, the operations of the employer. 
together labor and capital in order to produce goods or services for customers. If retirement plan law requires an employer to provide retirement benefits to certain employees, the cost of those benefits must be paid from a reduction in other forms compensation that the employees receive, from a reduction in the financial returns that owners receive, or from an increase in the prices that the employer charges customers.

If the employer sells its products into a competitive market, it cannot shift the costs of mandated benefits to customers through increased prices. In economic theory, in a competitive market, products from different producers are substitutes for each other, and the customers will purchase the lower priced products. Thus, unless all producers were affected equally by the increased costs of retirement benefits, the employer that raised its prices to pass the costs along to customers would lose sales, and ultimately would go out of business. The voluntary nature of retirement plan sponsorship virtually insures that some producers will respond to the costs of mandated benefits by terminating their retirement plans, thereby avoiding those costs. ${ }^{128}$ Lowercost producers will be successful, while employers who provide mandated benefits will face a higher cost structure and ultimately will go out of business.

If, instead of operating in a competitive product market, an employer holds power to control prices in its market, then it is possible that customers would bear the some of the costs of increased retirement benefits. Given product market power, the employer can raise prices to cover the costs of additional mandated benefits. After the mandate, the employees receive their original compensation packages, plus any additional mandated benefits, and they do not pay any implicit prices for the additional benefit. Assuming that the employees' original compensation packages reflected their market rates of compensation, after a legislated benefit increase, the employees receive compensation in excess of their market rates. This suggests that mandated

${ }^{128}$ Suppose two employers, "G" and "S," both sponsor retirement plans and that Congress amends retirement plan law to increase the costs of the benefits that are provided by the plans. $\mathrm{G}$ and $\mathrm{S}$ both produce goods that are sold in a competitive market. Assume that because of labor market conditions, neither employer can reduce the salary that is being paid to employees who receive the new, additional benefits required by law, so that the costs of the benefits cannot be imposed on the employees. Consider the results if $\mathrm{G}$ pays the higher retirement plan contributions and raises its prices to cover the costs, while $S$ terminates its plan, increases its employees' salaries by the amounts it formerly spent on retirement benefits, and holds its prices constant. G cannot succeed with its new, higher price. G must either follow S's lead and terminate G's retirement plan or go out of business. 
benefits legislation raises the compensation of employees who are employed in noncompetitive markets to above-market levels, and imposes additional costs on consumers generally. ${ }^{129}$ In general terms, the shifting of costs to customers depends on conditions in the product or service markets into which the employer sells. ${ }^{130}$

Owners of employers are the third category of candidates to bear the costs of legislated retirement benefit increases. The analysis about shifting of costs to owners is analogous to that about shifting of costs to customers. ${ }^{131}$ If an employer provided mandated benefits, and if it paid for these benefits by reducing the returns paid to its owners, assuming that the owners' capital were liquid, they would withdraw their capital from the employer and re-deploy it to other opportunities that offered a competitive rate of return. The shifting of costs to owners depends on conditions in the capital markets.

The shifting of costs of retirement benefits to an employer's customers or owners ultimately depends on conditions in product and capital markets. Many U.S. product markets are competitive, and much capital is raised in capital markets that are generally efficient. For employers in these markets, costs of retirement benefits are not likely to be borne by customers or owners in the long run. This leaves the conclusion that employees will bear the costs. ${ }^{132}$ This is the third major premise for the argument that employees largely receive just the retirement benefits that they are willing to pay for.

${ }^{129}$ The increased prices will result in a reduced demand for the employer's products or services, leading to reduced production, and reduced employment by the employer. The proportion of the costs of mandated benefits that can be shifted to customers depends on the elasticity of their demand. With greater elasticity, the cost increase attributable to mandated benefits is smaller than would have been associated with the pre-mandate employment level. Employment reductions by employers affected by mandated benefits will affect compensation and employment levels generally.

${ }^{130}$ CITE, Wolk, Discrimination Rules, supra note , at . (suggesting that the surplus might be allocated to employees, employer's owners, or customers).

${ }^{131}$ If, continuing the above example, $\mathrm{G}$ and $\mathrm{S}$ obtain capital in competitive capital markets, and if $\mathrm{G}$ reduces the returns to its owners in order to pay increased costs of retirement benefits while $S$ avoids the increased costs, owners will withdraw capital from $\mathrm{G}$, and shift capital to S. If the capital markets are not completely liquid, that is, if the owners of $\mathrm{G}$ do not have ready alternatives to their investment in $G$, then they have to accept the reduced returns from $\mathrm{G}$.

${ }^{132}$ Some retirement plan scholarship assumes that employers bear the costs of retirement benefits. 


\section{Employer Surplus and Productivity Gains from Retirement Plans}

So far we have focused on the added utility, or value, that a retirement plan might provide for employees. Retirement benefits increase the utility of a compensation package when the employee values the retirement benefits more highly than the implicit price that the employee pays for the benefits. A retirement plan can also create additional value for an employer; this additional value arises from two sources. An employer may be able to capture part of the employee surplus that arises with its employees; section 1 below describes this process and defines the term "employer surplus" to refer to this captured portion of the employee surplus. Retirement benefits can also add value for an employer by allowing it to assemble, retain, and motivate a workforce that is more productive than its workforce would be in the absence of retirement benefits; section 2 below develops these effects and defines these employer gains as "productivity gains."

\section{Employer Surplus}

In a formal sense, employee surplus initially arises on the employee's side of the employment relationship. Employee surplus stems from income tax reductions and from some of the non-tax attributes associated with retirement benefits. The income tax reductions are, as a matter of the incidence of payment of the taxes, reductions in the employee's income tax liabilities. From the employer's income tax perspective it is a matter of indifference whether compensation is paid as salary or as a contribution for retirement benefits; both payments are currently deductible by the employer. ${ }^{133}$ Because it is the employees' tax liabilities that are reduced, the surplus generated by those reductions arises with employees. Similarly, employee surplus generated by the non-tax attributes of retirement benefits arises with employees. However, the fact that employee surplus arises with an employee does not imply that the employee necessarily retains and enjoys the entire surplus for herself. ${ }^{134}$

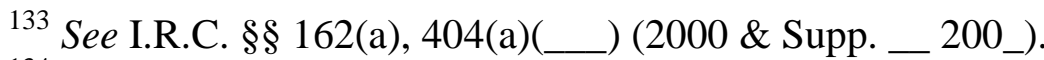

134 This discussion of the origin and ultimate capture of employee surplus is analogous to the analysis of the incidence of the cost of retirement benefits. While the incidence of payment for the benefits is on the employer, we have seen that the cost is shifted to employees. See supra note __ and accompanying text. In the case of employee surplus, employees receive the payment of the income tax reductions since they pay lesser amounts of income tax; however this fact does not determine the extent to which the employees or their employer finally capture the value of those tax reductions. 
In some circumstances, an employer might capture some of the value that initially arises on the employee's side of the relationship. The employer would capture part of this value when its costs for a compensation package that included retirement benefits were less than the cost of paying an employee purely in salary. In other words, an employer could enjoy compensation cost savings by paying employees partly with retirement benefits. These compensation cost savings for the employer are referred to as "employer surplus"; the employer surplus is equal to the excess of an employee's implicit price for her retirement benefits over her employer's costs for those benefits. $^{135}$

\section{Example 3}

An Employer Captures Employer Surplus when the Employee Pays an Implicit Price that Exceed the Employer's Costs for the Employee's Retirement Benefits

Facts: W receives a salary of $\$ 95,000$ and her benefits cost $\$ 10,000$. W's compensation package costs her employer $\$ 105,000$.

W's market rate of total compensation is $\$ 110,000$; this assumed market rate of total compensation is the baseline from which W's implicit price of her retirement benefits is calculated. ${ }^{136}$ If $\mathrm{W}$ were paid entirely with salary, she would have received $\$ 110,000$ of salary.

The difference between the $\$ 110,000$ market rate of compensation and W's $\$ 95,000$ salary is the implicit price that she pays for her retirement benefits, in this case $\$ 15,000 .^{137}$

${ }^{135}$ Cf. Joseph Bankman, The Effect of Anti-Discrimination Provisions, supra note , at 606 ("The favorable tax provisions can be described as a wage subsidy that increases with increasing employment of highly compensated workers"); Wolk, Discrimination Rules, supra note 26, at 432 ("For example, an employee who was paid $\$ 50,000$ before the plan's establishment might only demand a salary of $\$ 44,500$ if an additional $\$ 5,000$ is contributed to the retirement plan. The total wage cost to the employer would therefore actually drop from $\$ 50,000$ to $\$ 49,500$.”)

Compare the previous example of employee $\mathrm{H}$, in which the employer did not capture any of the employee surplus. See supra note ___ and accompanying text. H values her retirement benefits at $\$ 14,300$, and she pays an implicit price of $\$ 10,000$ for these benefits. The employer's cost of the benefits was $\$ 10,000$; the employer's total compensation cost for $\mathrm{H}$ remains $\$ 110,000$, which is H's market rate of total compensation. The employer has not captured any of the employee surplus generated by the retirement benefits.

${ }^{136}$ The market rate of compensation can be determined only by economic and statistical studies that measure the compensating differentials associated with retirement benefits.

${ }^{137} \mathrm{~W}$ chooses to receive retirement benefits because the utility of these benefits has a value that exceeds her implicit price. See supra note and accompanying text. W's implicit price is $\$ 15,000$, so the value of the retirement benefits must exceed $\$ 15,000$. In the previous example of $\mathrm{H}$, she valued her retirement benefits based on avoidance of current income taxation. See supra note and accompanying text. If $\mathrm{W}$ also based her valuation on current income tax 
Conclusions: $\mathrm{W}$ is a willing employee because the implicit price that she pays, $\$ 15,000$, exceeds the employer's cost of her benefits, $\$ 10,000$.

W's employer captures employer surplus of $\$ 5000$. This is the compensation cost savings arising from providing $\mathrm{W}$ with a compensation package that costs $\$ 105,000$, rather than paying her $\$ 110,000$ of salary.

Employer surplus can arise only in connection with the provision of retirement benefits to willing employees. ${ }^{138}$ By definition, willing employees are those who pay an implicit price that at least equals, or exceeds, the cost of retirement benefits. ${ }^{139}$ So only a willing employee pays an implicit price that exceeds the employer's costs of benefits. Also, recall that an employee agrees to pay an implicit price for retirement benefits when the retirement benefits provide employee surplus, that is, when the utility derived from the retirement benefits exceeds the utility that the employee would have derived from the salary that is applied to pay the implicit price. Thus, in Example 3, when W pays an implicit price of $\$ 15,000$, it must be the case that W's retirement benefits have a value to her of $\$ 15,000$ or more.

\section{Productivity Gains}

A retirement plan can cause a workforce to be more productive than it would be in the absence of the plan. ${ }^{140} \mathrm{We}$ will refer to the gains that result from this enhanced productivity as "productivity gains." Productivity gains initially arise on the employer's side of the employment relationship since they enable the employer to increase its output with the same quantity of labor.

avoidance, and if her marginal tax rate were higher than H's $30 \%, \mathrm{~W}$ could conclude that retirement benefits that cost her employer $\$ 10,000$ have a value to her greater than $\$ 15,000$. W might also assign value to her retirement benefits because of other attributes that they bring to her. See supra note ___ and accompanying text.

CITE. There is a fn. that references that employees with higher incomes demand more retirement benefits.

${ }^{138}$ Cf. Halperin, Special Tax Treatment, supra note, at 14 ("It may be that higher income employees, who prefer [retirement benefits] . . will accept a pay reduction greater than the contribution made to the retirement plan on their behalf"); but cf id at 47 ("In a simple model, it is reasonable to assume that the employee would capture the tax subsidy."

CITE. Halperin, Special Tax Treatment, supra note, at 14 cites to Wolk, Discrimination Rules, supra note, at 429-34.

${ }_{140}^{139}$ See supra note ___ and accompanying text.

${ }^{140}$ Ippolito, Employee Performance, supra note, at 27. Halperin, Special Tax Treatment, supra note, at 14. Cf. John H. Langbein, The Supreme Court Flunks Trusts, 1990 Sup. Ct. Rev. 207, 212 (1991) ("In truth, ERISA plans are not for the exclusive benefit of the employees; they 
Productivity gains arise from an employee bonding effect and from a sorting effect. The bonding effect occurs when a retirement plan lengthens job tenures. ${ }^{141}$ A simple example of this effect depends on deferred vesting of retirement benefits. After employees have earned some retirement benefits but are not yet vested in those benefits, the risk of forfeiture of the accumulated value discourages some employees from quitting, at least until they become $100 \%$ vested. Similarly, in a defined benefit plan, "backloading” of benefit accrual may encourage participants to remain with the sponsoring employer until they have accrued most or all of their potential benefits. There are two ways in which increased job tenures can improve productivity. More experienced employees can be more productive, and longer job tenures are associated with greater employer investment in general training of employees. ${ }^{142}$

An employer might use a retirement plan as an employee sorting device. A plan can serve this function if some types of potential employees are particularly interested in receiving retirement benefits and would select themselves into jobs that included retirement benefits as part of the compensation. Professor Ippolito suggests that individuals who are "low discounters" are more interested in retirement benefits than workers in general, and that low discounters may also be more productive workers. ${ }^{143}$ If this is true, a sponsoring employer might be able to use a retirement plan as a device to assemble a workforce that is more productive than would be the case if all compensation were paid as salary.

Of course, sponsorship of a retirement plan involves additional costs. Providing employees with retirement benefits costs more than simply paying salaries equal to the costs of benefits. Obviously, in order for there to be employer surplus and productivity gains, the plan must add at least enough value to pay the additional costs associated with plan sponsorship. ${ }^{144}$ If there are surplus and gains beyond this threshold, there remains the question of who captures this added value in the long run.

are for the joint benefit of employer and employees.").

${ }^{141}$ See generally Richard A. Posner, Aging and Old Age (U. Chicago Press 1995); Stein, Agenda for Reform, supra note, at .

${ }_{142}$ Gary S. Becker, Human Capital (3d ed. U. Chicago Press 1993).

${ }^{143}$ See generally Ippolito, Employee Performance, supra note, at ; Ehrenberg \& Smith, supra note , at 380-81.

${ }^{144}$ Wolk, Discrimination Rules, supra note 26, at 430 ("Establishment and maintenance of a qualified plan involve significant administrative costs.”) 
While the gains that create employee surplus initially arise with the employee, and productivity gains initially accrue to the employer, these facts do not imply that the employee retains all of the employee surplus nor that the employer retains all the productivity gains. These gains are similar to the other gains that are created by an employment relationship. The employment relationship is a joint project, and there is simply no a priori solution to dividing gains that are produced jointly. A common theory is that the gains will be divided in accordance with the parties' relative bargaining power, and different situations will result in different outcomes. The division of the employee surplus and productivity gains between an employer and its employees depends on labor market conditions. ${ }^{145}$ As we will see below, in order for retirement plan law to actually cause retirement plans to provide more retirement benefits to nonhighly compensated employees than these employees buy for themselves, it is necessary for an employer to capture some employer surplus and to retain some productivity gains. If employees retain all of the employee surplus and if they, or the employer's customers or owners, capture all of the productivity gains, retirement plan law can have no effect on the amounts of retirement benefits received by nonhighly compensated employees. ${ }^{146}$

\section{Retirement Plan Law and Employees’ Preferences}

Earlier we noted that retirement plan law specifies the terms and conditions that comprise an employee's retirement benefits rights. But the law has grander aspirations than simply protecting workers from oppressive terms of employment. Retirement plan law aims to advance two social policy goals: to increase the amounts that employees save for retirement and to cause retirement plans to provide more retirement benefits to nonhighly compensated employees than these employees would buy for themselves. The first goal is implemented with income tax

${ }^{145}$ Compare Joseph Bankman, The Effect of Anti-Discrimination Provisions, supra note 26, at 603 (arguing that in the shork term, the income tax savings should accrue to employers; with Halperin, Special Tax Treatment, supra note 26, at 47 ("In a simple model, it is reasonable to assume that the employee would capture the tax subsidy."), and with Wolk, Discrimination Rules, supra note 26, at 432 ("Once the trade-off between wages and retirement benefits had occurred and equilibrium was established, the tax subsidy would be distributed in some fashion among numerous potential recipients, including high-paid employees, low-paid employees, the employer, or perhaps even the consumer in the form of lower prices for the employer's products.") Gary S. Becker, Human Capital (3d ed. U. Chicago Press 1993). Richard A. Epstein, In Defense of the Contract at Will, 51 U. Chi. L. Rev. 947 (1984).

${ }^{146}$ See infra note ___ and accompanying text. 
provisions that reduce the tax burden on an employee's savings that she receives and holds as retirement benefits. The second is pursued with the benefit allocation rules. These topics are taken up in the two sections that follow.

1. The Income Tax Preference for Retirement Benefits.

While the inclusion of retirement benefits in an employee's compensation package is voluntary, Congress influences this choice by reducing the employee's income taxes when she receives compensation in the form of retirement benefits rather than as salary. When an employee receives retirement benefits as compensation, the value of the benefits is not included in the employee's income for tax purposes; of course salary is fully taxable upon receipt. This means that some employees, especially higher-paid employees, will value retirement benefits more highly than if the cost of those benefits were instead were paid to the employee as taxable salary. Under the hedonic wage model, employees receive the retirement benefits that they are willing to pay for. By exempting retirement benefits from current income taxation, Congress has made them relatively more valuable and employees therefore buy more retirement benefits than they otherwise would. This results in employees accumulating more retirement savings.

We have noted that an employee's accumulated retirement benefits are simply the employee's retirement savings. Lower income taxes are imposed on retirement savings as compared with other forms of savings. The general income tax treatment of savings, savings that we might call "regular savings," 147 provides that when an individual saves part of her income, the amount saved is currently taxed; that is, the principal saved is reduced by the taxes paid. The income earned on this after-tax amount is itself taxed. Subsequent withdrawals from the savings account are not taxed, since both the principal and income have already been taxed. In contrast, retirement savings are not taxed when accumulated and the income earned on the retirement savings is exempt from current income taxation, but when the plan distributes the retirement savings to the participant, the entire amount distributed is taxed to the participant. ${ }^{148}$

${ }^{147}$ Regular savings are savings that an individual accumulates subject to the general rules of income taxation. Regular savings are not subject to any of the special income tax rules that apply to retirement savings, or to other savings that enjoy special tax treatment such as savings for education.

${ }^{148}$ The income tax exemption for retirement funds is implemented by several rules. First, when an employee receives compensation in the form of a retirement benefit, the value of that benefit is not included in the employee's gross income for income tax purposes. See I.R.C. § 
The income tax treatment of retirement savings is equivalent to a permanent exemption from income taxation of the investment income earned on the retirement savings, assuming no change in income tax rates between the time of payment of contributions and distribution of retirement benefits. ${ }^{149}$ Thus, the investment income earned on retirement savings is exempt from income taxation, while the income earned on regular savings is currently taxed. Because of this exemption, when all else is equal, retirement savings will yield larger accumulations than regular savings. ${ }^{150}$ In addition, if a retirement plan participant's income tax rate is lower at the time her retirement savings are distributed to her, a time when the participant presumably is retired from active employment, the advantage of retirement savings can be magnified. ${ }^{151}$ These income tax rules create a powerful incentive for individuals to arrange their savings as retirement savings, rather than as regular savings. ${ }^{152}$

A typical employee may not understand the analysis that equates the income tax treatment of her retirement savings with the permanent exemption for the investment income earned on those savings. However, she is quite likely to fully appreciate that compensation received in the form of retirement benefits is preferable to taxable compensation, assuming that she otherwise intends to save a portion of her income. In our earlier example, employee $\mathrm{H}$ added

402(a) (2000 \& Supp.__ 200__); Treas. Reg. § 1.402_____ (as amended in 199_). Second, when an employer pays a contribution to a retirement plan to fund the employee's retirement benefit, the employer is allowed an income tax deduction for the contribution up to certain statutory ceilings. The effect of these rules is to exempt the principal amount of retirement funds from current income taxation. Third, the investment income earned on funds held for future retirement income payments is exempt from income tax. Finally, when retirement income payments are distributed to the participant, she includes the full amount distributed in her income. note, at .

${ }^{149}$ See Halperin, Special Tax Treatment, supra note, at 13; Halperin, Time Value, supra

${ }^{150}$ CITE. The 2003 Tax Act reduced the tax rate applicable to dividend income so that dividends from domestic corporations are taxed at a maximum 15\% rate. This change, in effect, reduces the tax subsidy to retirement plans and makes them relatively less attractive from a tax standpoint than prior to the Act. However, retirement plans still offer a lower rate of tax than regular savings.

${ }^{151}$ See generally Langbein \& Wolk, supra note , at .

152 See generally Graetz \& Mashaw, supra note , at 108 ("Tax incentives to employerprovided pensions have inspired both employers and workers to substitute retirement income payments for current compensation and have produced a substantial shift away from other savings toward pensions."); Langbein \& Wolk, supra note , at . 
$\$ 4300$ of value to her compensation package by substituting $\$ 10,000$ of non-taxable retirement benefits for $\$ 10,000$ of taxable salary. ${ }^{153}$

It is necessary to limit the scope of the income tax preference for retirement savings, lest taxpayers transform excessive amounts of their taxable income into retirement benefits and transform their regular savings into retirement savings. The most basic limitation on retirement savings is the requirement that an individual must earn income by working in order to accumulate retirement savings; investment income may not be saved on a tax-preferred basis for retirement. ${ }^{154}$ In the case of a person employed as a common law employee, her labor income is the "compensation" that she earns from her employer. Retirement plan law permits an employer to contribute to its retirement plan only for the benefit of an employee who earns compensation

${ }^{153}$ See supra note ___ and accompanying text.

${ }^{154}$ Retirement plan law has always limited the income tax preference for retirement savings to labor income, and this rule is one of the few constants in the field. For individuals who desire to save, the tax preference for retirement savings creates an incentive to generate labor income since this is the general and necessary requirement for the accumulation of retirement savings. The tax law portions of retirement plan law label labor income as "compensation," or in the case of a self-employed person, as "earned income" "Compensation" is defined as "the compensation of the participant from the employer for the year." Id. § 415(c)(3)(A); see also id. $\S 414(\mathrm{~s})$. The regulations offer much more specificity about the various elements of an employee's compensation package that may be included in a retirement plan's definition of compensation. Treas. Reg. $\S \S 1.414(\mathrm{~s})-1$ (as amended in ), $1.415-2$ (as amended in The law generally equates a self-employed person's income with compensation. See id. § 415(c)(3)(B) (2000 \& Supp. _ 200_). Tax law then provides that contributions to a retirement plan for the individual may be made only when the individual has earned compensation.

Most significantly, this means that an individual may not contribute any part of her investment income to a retirement savings program. And an individual may not contribute any part of her retirement income payments to a retirement savings program. Generally the amount distributed from a retirement plan to a participant is included in the participant's income. See id. $\S 402$ (a). There is no provision that allows a contribution to a retirement plan, or an individual retirement plan, based upon a distribution received from a retirement plan. $C f$. id. $\S \S 219$ (b)(1), 404(a)(1)(A), (3)(A). There is a limited exception for so-called rollover transfers. If a participant's distribution met the requirements for an "eligible rollover distribution," if it were transferred to an "eligible retirement plan," and if the rollover transaction satisfied all the requirements for a rollover, then the amount distributed could be excluded from the participant's income. See I.R.C. § 401(c) (2000 \& Supp. _ 200_).

By limiting the retirement savings income tax preference to labor income, retirement plan law improves the attractiveness of labor income, at least for those who desire to save, as compared with income from other activities. By reducing the income taxation of the retirement savings portion of labor income, retirement plan law improves the relative appeal for savers of working, as opposed to other activities. 
from the sponsoring employer. ${ }^{155}$ In most cases the amount that may be contributed to a retirement plan for an individual in a given year may not exceed the amount of compensation that is includible in the employee's taxable income in that year. ${ }^{156}$ For example, if an employee participated in her employer's defined contribution plan and if she were paid a salary of $\$ 40,000$ for a year, the employer could not contribute more than $\$ 40,000$ to the retirement plan for her for that year. ${ }^{157}$

In addition to the basic and general condition that only labor income may be saved for retirement, retirement plan law imposes many technical limitations on the accumulation of retirement savings. Some limitations may be logical; for example, contributions to a retirement plan may not be based on that part of an employee's compensation that exceeds $\$ 200,000 .{ }^{158}$ Other limitations on retirement savings are arbitrary; for example, consider a worker who is employed as a common law employee. Retirement plan law offers her two basic alternatives, which are not necessarily mutually exclusive: her employer might sponsor a retirement plan or she might establish an individual retirement account, commonly referred to as an "IRA," for herself. ${ }^{159}$ The employer may contribute up to $\$ 40,000$ per year on behalf of a participant in its

${ }^{155}$ In the case of a defined contribution plan the Code limits contributions to the amount of the participant's compensation. I.R.C. $§ 415(c)(1)(B)$ (2000 \& Supp. _ 200_). In the case of a defined benefit plan, the connection is less direct; the promised benefit may not exceed $100 \%$ of the participant's compensation, and contributions may be made only to fund benefits. $I d$. $\S \S$ 404(a)(1), 415(b)(1)(B).

${ }^{156}$ See I.R.C. $\$ 415(\mathrm{c})(1)(\mathrm{B})$ (2000 \& Supp. _ 200_) (limiting the amount that may be added to a participant's individual account in a defined contribution plan). In addition to limitations on the amount that may be allocated to a participant in each year, the Code limits the amount that the employer may deduct for a contribution. Id. $\S 404$ (a). As a practical matter, the limitations on deductions also serve as limits on contributions. In some situations the contributions that are made to a defined benefit plan for a participant for a given year might exceed the participant's taxable compensation.

${ }_{158}^{15}$ See I.R.C. $\S 415(\mathrm{c})(1)(\mathrm{B})$ (2000 \& Supp. _ 200_).

158 See I.R.C. $\S 401(\mathrm{a})(17)$ (2000 \& Supp.__200_).

${ }^{159}$ Another type of retirement savings program is the "individual retirement plan," a retirement savings plan that an individual establishes for herself. See I.R.C. § 7701(a)(37) (2000 \& Supp. _ 200_). Individual retirement plans include individual retirement accounts and individual retirement annuities, commonly referred to as an "IRA." Id. There are two types of IRAs, the traditional IRA, which enjoys the same pattern of taxation as an employer-sponsored retirement plan, and the "Roth IRA." See id. $\S \S 408,408$ A. The plan may be in the form of an "individual retirement account," or an "individual retirement annuity," both commonly referred to as an "IRA." See I.R.C. $§ 408$ (2000 \& Supp. _ 200_). An individual may establish an IRA and contribute to it if she earns compensation from a common law employment relationship or 
employer-sponsored retirement plan. ${ }^{160}$ In contrast, an individual may contribute only $\$ 3000$ to her IRA. ${ }^{161}$ Thus, an employee who desires a high level of retirement savings has an incentive to choose employment with an employer that sponsors a retirement plan, and makes large contributions to it. If the employee is unable to find a job that offers her the high level of retirement savings that she prefers, then she will be remitted to the IRA alternative and limited to tax-favored retirement savings of $\$ 3000$ per year. The income tax portions of retirement plan law create many incentives and disincentives for employers and employees to arrange their relationships to achieve or avoid particular retirement savings consequences. However, it is generally the case that the income tax preference for retirement benefits causes employees to accumulate more savings that are earmarked for retirement than would be accumulated in the absence of the preference. ${ }^{162}$

generates earned income from self-employment. See I.R.C. § 219(f)(1) (2000 \& Supp 200_). The deduction for a contribution to an IRA is limited to the amount of the owner's "compensation." See id. § 219(b)(1). In general terms, compensation means income that the owner earns from performing personal services. See id. § 219(f)(1). In the case of spouses who file a joint return, a contribution for the spouse with less compensation can be made based upon the compensation of the other spouse. See id. § 219(c).

${ }^{160}$ See I.R.C. $\$ 415(c)(1)(A)$ (2000 \& Supp. _ 200_). Availability of this $\$ 40,000$ limitation depends upon numerous conditions; a few of the salient requirements are that the employer must sponsor a "defined contribution plan," see id. § 415(c)(1), infra note __ and accompanying text; the employee must earn at least $\$ 40,000$ of compensation, see I.R.C. § 415(c)(1)(B) (2000 \& Supp.__ 200_); and other employees of the employer must receive benefits that are reasonably comparable with the $\$ 40,000$ contribution, see id. § 401(a)(4), infra note __ and accompanying text. Other limitations apply to a "defined benefit plan," see I.R.C. $\S 415$ (b) (2000 \& Supp. _ 200_), infra note __ and accompanying text.

A different limitation applies to a participant in a simple retirement plan. The analogous ceiling on a contribution to a simple retirement plan or simple retirement account is $\$ 8000$ (in the 2003 year; the ceiling is raised in future years). See id. $\$ 408(\mathrm{p})(2)(\mathrm{E})$.

${ }^{161}$ See I.R.C. $\$ 219(\mathrm{~b})(5)(\mathrm{A})(2000$ \& Supp. _ 200_). The $\$ 3000$ ceiling applies in the years 2003 and 2004; the ceiling is raised in future years. Id. (annual deductible amount for individual retirement contributions is \$4000 in 2005 through 2007, and \$5000 in 2008 and thereafter). Additional, "catch-up" contributions are allowed for an individual age 50 or older in the amounts of $\$ 500$ in 2003 through 2005, and \$1000 in 2006 and thereafter. See I.R.C. § 219(b)(5)(B) (2000 \& Supp. _ 200_).

${ }^{162} C f$. Langbein \& Wolk, supra note 26 , at 30 ("To the question, how much of the private pension system would survive if it were tax-neutral, the answer would surely be, 'Much less.'”) 


\section{Benefit Allocation Rules}

The benefit allocation rules cause some retirement plans to provide some nonhighly compensated employees with more retirement benefits than these employees pay for. ${ }^{163} \mathrm{~A}$ fundamental purpose of these rules is to mitigate a tendency that pervades the private retirement plan system: the system tends to provide more retirement benefits to higher-paid employees than to lower-paid employees. ${ }^{164}$ After canvassing data about which workers receive benefits from private retirement plans, Professors Langbein and Wolk conclude that " $[\mathrm{t}]$ he voluntary private pension system covers only about half the workforce, and in general it is the [better-paid] half." 165 These data confirm the theory that employees' preferences and choices control their retirement benefits and that employees buy the amounts of retirement benefits that they want. There are good reasons to believe that most higher-paid employees prefer a higher proportion of retirement benefits in their compensation packages than do lower-paid employees. ${ }^{166}$ First, an

163 The benefit allocation rules include the rules that govern coverage, participation, nondiscrimination in contributions or benefits, accrual, vesting, and benefits payment. See I.R.C. $\S \S$ 401(a), (a)(4), (a)(9), 410, 411 (2000 \& Supp. _ 200_); see infra notes 170-190 and accompanying text. These rules regulate which employees, from among all of an employer's employees, will receive benefits from a particular retirement plan. The benefit allocation rules are all conditions that a retirement plan must satisfy in order to "qualify" for the exemption from income taxation. See I.R.C. § 401(a) (2000 \& Supp. _ 200_); see generally Langbein \& Wolk, supra note 26 , at 234-240.

${ }^{164}$ It has long been accepted that since retirement benefits enjoy tax-favored treatment, it is appropriate to limit the tendency of retirement plans to provide disproportionately higher levels to benefits to higher-paid employees. Congress has been unwilling to permit retirement plans to be used as a device for delivering tax-exempt compensation only to higher paid employees.

The belief that it is appropriate to limit the degree to which retirement plans may disproportionately benefit highly compensated employees depends in part on an assumption that has not been tested: it assumes that the higher-paid employees capture most or all of the surplus created by a retirement plan. That is, it is assumed that employees retain the employee surplus created by a retirement plan. If in fact, employers capture most of the surplus, then higher-paid employees are not in fact a great deal better off for having received retirement benefits instead of additional salary. For example, if the employer surplus is applied to reduction of the prices of the employer's products, then consumers benefit from the tax preference for retirement benefits.

${ }^{165}$ Langbein \& Wolk, supra note, at 29.

${ }^{166}$ It is not possible to observe peoples' preferences directly; they can only be inferred by observing the priorities in which people apply their available resources. Given that employees pay for their retirement benefits and that higher-paid employees receive more retirement benefits, the conclusion follows that employees who earn more compensation prefer more retirement benefits in the sense of being willing to pay for more benefits. This suggests that they 
employee's marginal salary amounts are taxed at the employee's highest tax rate, which generally will be higher for higher-paid employees than for lower-paid employees. As compared with the after tax-value of marginal salary, tax-exempt retirement benefits are relatively more valuable to a higher-paid employee. Second, higher-paid individuals generally save larger proportions of their incomes than do lower-paid individuals. ${ }^{167}$ Lower-paid employees have more immediately pressing needs than saving for a perhaps far-off and uncertain retirement. ${ }^{168}$ Thus, when a retirement plan provides a higher level of retirement benefits to higher paid employees than to lower-paid employees, the plan is responding to the higher-paid employees' preferences for these benefits (preferences in this sense meaning a willingness to pay for the benefits). ${ }^{169}$

The benefit allocation rules mitigate this tendency of retirement plans to provide disproportionately more retirement benefits to the higher-paid employees by requiring that if a retirement plan provides retirement benefits to even one of the sponsoring employer's highly compensated employees, then it must provide one or more nonhighly compensated employees with reasonably comparable benefits. The benefit allocation rules require a plan to provide

have stronger preferences for these benefits than lower-paid employees. Obviously there is an important income effect; higher-paid employees have more resources, they have satisfied more of their higher priority needs, and they therefore have income available to save in the form of retirement benefits.

${ }^{167}$ Daniel Shaviro, Making Sense of Social Security Reform 10 (2000) ("Poorer people in particular may tend ... to discount future benefits more steeply than other individuals. Evidence that this is so can perhaps be deduced from studies of life-cycle saving patterns, which suggest that people with lower lifetime earnings generally save a lower percentage of what they have.")

${ }^{168}$ Cf. Halperin, Special Tax Treatment, supra note, at 14 ("Lower-paid employees cannot be expected to provide for the future when current income is barely adequate for a minimum standard of living. In these situations, employees would be unwilling to accept a reduction in current wages. . . . .); Bankman, Tax Policy and Retirement Income, supra note , at 807-08 ("It is generally expected, however, that the desired percentage of compensation to be received in the form of pension benefits will be greater for highly compensated employees than for [nonhighly compensated employees]. In general, highly compensated employees will save a larger percentage of their income than will [nonhighly compensated employees].")

Citing President's Commission on Pension Policy, Coming of Age: Toward a National Retirement Income Policy at 35 (1981); Nancy J. Altman, Rethinking Retirement Income Policies: Nondiscrimination, Integration, and the Quest for Worker Security, 42 Tax L. Rev. 433, at 435-36 (1987).

${ }^{169}$ See Wolk, Discrimination Rules, supra note 26, at 432 ("[G]iven the choice to select employees for retirement plan coverage, employers would generally cover only highly compensated employees."); Weiss, supra note 26, at 1294 ("Left to their own devices, employers will provide more generous pensions to high income workers.") 
benefits to nonhighly compensated employees by regulating each stage of an employee's journey from the beginning of her employment with an employer that sponsors a retirement plan to her final receipt of retirement income payments from her employer's plan. The rules regulate which employees must be "covered" by a retirement plan, when covered employees become participants in the retirement plan, the amounts of benefits that are allocated participants, the rates at which participants earn, or "accrue," their benefits, when participants become vested in the benefits, and when the benefits must be paid to retired participants. As a mechanical matter, these rules regulate the substantive content of every retirement plan document; the provisions included in the plan document define which employees receive what amounts of retirement benefits. By specifying how the plan defines the benefits that employees receive, the benefit allocation rules indirectly control the amounts of benefits that the employees receive. In the most general terms, the benefit allocation rules require that if a retirement plan provides retirement benefits to even one highly compensated employee, then it must provide one or more nonhighly compensated employees with reasonably comparable benefits.

The definition of nonhighly compensated employees is basic to the benefit allocation rules. It is a residual category; ${ }^{170}$ it includes all of an employer's employees other than "highly compensated employees." " The "highly compensated employee" category includes those employees who, in general terms, earn more than $\$ 90,000$ and are in the highest paid $20 \%$ of all of the employer's employees, or who own at least $5 \%$ of the ownership interests in the employer. ${ }^{172}$ All the remaining employees are nonhighly compensated employees. Since only about $4 \%$ of workers earn more than $\$ 80,000$, the great majority of employees are nonhighly compensated employees. ${ }^{173}$

${ }^{170}$ See Treas. Reg. § 1.401(a)(4)-12, NHCE (as amended in 1993) ("NHCE [nonhighly compensated employee] means an employee who is not a HCE [highly compensated employee].)

${ }^{171}$ See I.R.C. \$ 414(q) (2000 \& Supp. _ 200_). The \$80,000 compensation amount stated in $\S 414(q)(1)(B)(i)$ has been adjusted with for increases in the cost-of-living. Id.; CITE . The limitation of the highly compensated employee category to only those employees who both earn more than $\$ 90,000$ and are in the highest paid $20 \%$ of the employees is elective with the employer. See I.R.C. § 414(q)(1)(1)(B)(ii). (2000 \& Supp. _ 200_).

${ }^{172}$ See I.R.C. § 414(q) (2000 \& Supp. _ 200_).

${ }^{173}$ CITE. update.

Data from the March 1997 Current Population Survey indicate that only $4.2 \%$ of all workers earned \$80,000 or more. Bureau of Labor Statistics, U.S. Dep't of Labor \& Bureau of the Census, March 1997 Supplement, Annual Demographic Survey, Table NC8, Pension plan 
The first step that an employee takes toward receiving retirement benefits is for her to become employed in a group of employees that is "covered" by a retirement plan. A plan covers a group of employees when employees who are employed in that group are eligible to become "participants" 174 in the plan after they fulfill any conditions that the plan states as requirements for participation. A retirement plan may cover all of the sponsoring employer's employees, or it may cover some defined group of employees, such as employees who are paid on a salaried (as opposed to hourly) basis, or employees who work at a particular location or in a specified line of business. ${ }^{175}$ If a retirement plan covers one or more of the sponsoring employer's highly compensated employees, then the law requires that the definition of the group of employees covered by the plan must be drawn so that the plan covers some of the sponsoring employer's nonhighly compensated employees; coverage may not be discriminatory in favor of highly compensated employees. ${ }^{176}$ In determining if a plan's coverage is discriminatory in favor of highly compensated employees, retirement plan law considers all of the employees of the sponsoring employer and all employees of employers that are under common control with the sponsoring employer. ${ }^{177}$ However, employees who are employed in a "separate line of business" may be excluded from the testing. ${ }^{178}$ The coverage rules insure that at least some of a (broadly defined) employer's nonhighly compensated employees take the first step toward ultimately

coverage of workers. The total number of workers was reported to be $144,582,000 ; 6,093,000$ were reported in compensation categories of $\$ 80,000$ and above.

${ }^{174}$ See ERISA $\S 3(7), 29$ U.S.C. $\$ 1002(7)$ (2000) ("[P] articipant means any employee or former employee of an employer . . . who is or may become eligible to receive a benefit of any type from an employee benefit plan which covers employees of such employer . . , or whose beneficiaries may be eligible to receive any such benefit").

${ }^{175}$ CITE. See Treas. Reg. $\$ 1.410\left(\_\right)$___ (as amended in 19__ ). A retirement plan might exclude all of an employer's employees who are paid on an hourly basis rather than on a salaried basis. The plan might limit participation to employees that work in a specified business division or geographical location.

${ }^{176}$ See I.R.C. $\$ \S 401(a)(4), 410(b),(b)(2)(A) ~(2000 \&$ Supp. _ 200_). If the definition of the group were left unregulated, employers and employees could easily circumvent any legal rules that attempt to provide retirement benefits to particular employees; a plan would simply define its covered group of employees to be congruous with the group of willing employees who desire retirement benefits.

${ }^{177}$ See I.R.C. $\S \S 414(\mathrm{~b}),(\mathrm{c}),(\mathrm{m})$, (n) (2000 \& Supp. _ 200_). The employees counted for the determination about discriminatory coverage may exclude employees who have not satisfied any minimum age and service requirements for participation. See id. § 410(b)(4) (2000). ${ }^{178}$ See I.R.C. $\S \S 410(b)(5), 414($ r) (2000 \& Supp. _ 200_). 
receiving retirement income payments by requiring that some of these employees be included in the group of employees covered by a plan.

Once an employee is included in the group of employees covered by a retirement plan, the employee must next satisfy the participation requirements of the plan. Retirement plans typically limit participation to employees who have worked a certain minimum period of time for the sponsoring employer and who have attained a minimum age. Participation rules forbid a retirement plan from requiring that an employee complete a period of employment that exceeds one year (two years in certain cases), or attain an age older than age 21 , as conditions for participation in the plan. ${ }^{179}$ After an employee has satisfied the participation requirements, she becomes a participant in the retirement plan. A plan's participation requirements must apply uniformly to all employees covered by the plan, thereby assuring that if nonhighly compensated employees remain employed for a sufficient period, they will become participants in the plan on the same basis as highly compensated employees. The coverage and participation rules define legally acceptable middle ranges between the tendency of retirement plans to provide benefits only to willing employees and a requirement that a plan provide benefits to every nonhighly compensated employee. ${ }^{180}$

The heart of the benefit allocation rules is a regime known as the nondiscrimination rules. The nondiscrimination rules require that the plan allocate to the nonhighly compensated employee-participants retirement benefits that are reasonably comparable in amount to the

${ }^{179}$ See I.R.C. § 410(a) (2000 \& Supp. __ 200_).

CITE. Any participation rules that the plan imposes must apply uniformly to both nonhighly and highly compensated employees.

A collateral goal of the participation rules is to support the vesting rules; in order to effectively regulate vesting, it is necessary to also regulate plan participation, benefit accrual, and benefit payment. See Langbein \& Wolk, supra note, at .

${ }^{180}$ Some, perhaps many, of an employer's nonhighly compensated employees might be unwilling to pay sufficient implicit prices to cover the costs of their retirement benefits. See infra note ___ and accompanying text. In addition a requirement that a retirement plan had to provide benefits to every employee of the sponsoring employer would be, at least in part, wasteful. Consider an employee who might work for a sponsoring employer for a few hours or a few weeks when she is 25 years old; if the benefit allocation rules required the plan to provide this employee with retirement benefits, and if the benefits were not paid to the employee until she was 65 years old, the retirement benefit would have to be administered for 40 years. It would be wasteful to account for a small retirement benefit associated with such brief employment over a 40-year period. Therefore, the benefit allocation rules permit retirement plans to exclude from 
benefits allocated to highly compensated employee-participants. ${ }^{181}$ In effect, the nondiscrimination rules loosely tie together the rates of benefits that nonhighly and highly compensated employees receive. A defined contribution plan may calculate the rate of benefits that each participant receives by computing the percentage that the employer's contribution for a year comprises of the participant's compensation for that year. ${ }^{182}$ In Example 1, in one year $\mathrm{H}$ received $\$ 100,000$ of salary and her employer contributed $\$ 10,000$ to the plan on her behalf; ${ }^{183}$ these facts illustrate a contribution rate of $10 \%$. This example approximates one of the methods described in the treasury regulations that can be used to demonstrate that a defined contribution plan complies with the nondiscrimination rules; the regulations are extensive and offer numerous alternative methods of calculation of rates of benefits. ${ }^{184}$ If a sponsoring employer makes

participation certain defined categories of temporary, short-term, and part-time employees. ${ }^{181}$ See I.R.C. § 401(a)(4) (2000 \& Supp. _ 200_). The nondiscrimination rules apply only if a retirement plan provides retirement benefits to a highly compensated employee. If a plan does not benefit a highly compensated employee, the plan can allocate benefits among nonhighly compensated employees in any manner. See I.R.C. § 401(a)(4) (2000 \& Supp. 200_). If the plan covers only nonhighly compensated employees, then benefits can be provided to employees without regard to the benefit allocation rules. Cf. Halperin, Special Tax Treatment, supra note, at (suggesting that plans that provide retirement benefits to the better paid employees among the nonhighly compensated employees be considered for further regulation). There is of course no requirement for a plan to provide any benefits to highly compensated employees.

The requirement that benefits provided to nonhighly and highly compensated employees must be "reasonably comparable" is an extremely generalized description of the enormous body of law and regulation known as the nondiscrimination rules. The statutory genesis of this principle states that the retirement benefits provided by an employer-sponsored retirement plan must "not discriminate in favor of "highly compensated employees" See id. The "reasonably comparable" description of the nondiscrimination rules recognizes that to varying degrees, retirement plans are permitted to provide highly compensated employees with larger amounts of retirement benefits than are provided to nonhighly compensated employees. In other words, notwithstanding the statutory language, some discrimination in favor of the highly compensated is permitted.

${ }^{182}$ See Treas. Reg. $\$ 1.401(\mathrm{a})$ 183 See supra note and accompanying text.

${ }^{184}$ See Treas. Reg. $\$ 1.401(\mathrm{a})$ _____ (as amended in 19___). The calculation of contribution percentages under the regulations involves much more detail than this simplified example. The participant's "compensation" as defined in the regulations can include many items in addition to the participant's salary. CITE.

In the case of a defined benefit plan, the level of retirement benefits can be computed based upon the percentage relationship between the retirement benefit payment that an employee is projected to receive beginning at age 65 and the participant's compensation, as determined 
contributions to a defined contribution plan that are uniform percentages of each participant's compensation, the plan will comply with the nondiscrimination rules. ${ }^{185}$

The nondiscrimination rules do not demand arithmetic equality in the rates of contributions for nonhighly and highly compensated participants. For this reason, the nondiscrimination rules are described as loosely tying together the rates of the two groups. The rate for highly compensated employees may exceed the rate for nonhighly compensated employees so long as the disparity between these groups' rates does not exceed various amounts of disparity that are permitted by the nondiscrimination rules. ${ }^{186}$ For example, under the rules that permit a retirement plan to be "integrated" with Social Security, a nonhighly compensated employee who participates in a defined contribution plan might receive retirement benefits that equal $5.7 \%$ of her salary, while a highly compensated employee receives benefits that equal $8.5 \%$ of her salary. In this example, the integration rules permit the benefits rate of the highly compensated employee to exceed that of the nonhighly compensated employee by 2.8 percentage points; this would be an amount of disparity permitted by the regulations. ${ }^{187}$ The nondiscrimination rules specify various arithmetic tests for the maximum amounts of permitted disparity.

The benefit allocation rules include accrual rules that require that the retirement benefits that are allocated to participants must be accrued more or less ratably over a participant's entire career of service. The rules include vesting provisions that require that participants must become vested in their accrued benefits no later than upon completion of specified periods of employment with the sponsoring employer. ${ }^{188}$ Vesting rules further the receipt of retirement income payments by nonhighly compensated employees by forbidding a plan from imposing conditions that would result in nonhighlies forfeiting their retirement benefits prior to receipt of

under the regulations. CITE.

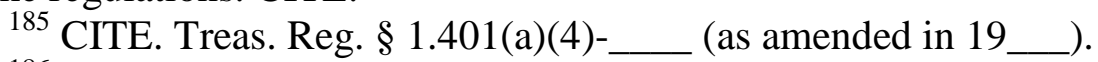

${ }^{186}$ See Treas. Reg. \& 1.401(a)-__ (as amended in 19__ ).

${ }^{187}$ See I.R.C. § 401(a)(5)(C)-(F), (1) (2000 \& Supp. _ 200_). The example illustrates integration of a defined contribution plan. See generally Langbein \& Wolk, supra note, at 31822 .

${ }^{188}$ Typically retirement plans provide that if an employee leaves employment prior to completion of a specified period of service, she will forfeit all or part of her accrued retirement benefits. 
payments. ${ }^{189}$ Payment rules require that (some) retirement income payments must be made during periods of time that may correspond to a participant's period of actual retirement.

The benefit allocation rules also impose a general nondiscrimination requirement; the retirement benefits that are received by nonhighly compensated employees must be comprised of terms and conditions that are no less favorable for these employees than the retirement benefits received by highly compensated employees. For example, a plan could not provide that the retirement benefits of highly compensated employees were always fully vested, while deferring the vesting of benefits of nonhighly compensated employees. Any plan provision that is available to highly compensated employees must also be available to nonhighly compensated employees. ${ }^{190}$ These requirements imply that both nonhighly and highly compensated employees receive retirement benefits that are uniform in quality.

The benefit allocation rules loosely tie together the quantity of retirement benefits that nonhighly and highly compensated employees receive and they require that the terms and conditions that comprise the retirement benefit rights be identical. By requiring that nonhighly and highly compensated employees receive retirement benefits that are uniform in quantity and quality, the benefit allocation rules standardize the benefits that employees receive. In the next section, we will consider how standardization of the quantity of retirement benefits results in some nonhighly compensated employees receiving more benefits than they pay for.

\section{Reluctant Employees and Mandated Retirement Benefits}

When the benefit allocation rules require that a retirement plan provide a reasonably comparable level of benefits to some nonhighly compensated employees, they create the possibility that an employee might receive more retirement benefits than she pays for. Earlier we developed the concept of the willing employee, the employee who pays an implicit price that

${ }^{189}$ In addition to insuring that some nonhighly compensated employees actually receive payment of retirement income, vesting rules reduce the risks protecting employees from excessively risky retirement benefits, restrict the extent to which employees who leave employment will forfeit their benefits, thereby increasing the likelihood that employees will receive retirement benefits.

${ }^{190}$ Rights and benefits must be available to a group of employees that satisfies the coverage requirements, and must not substantially discriminate in favor of highly compensated employees. See I.R.C. § 401(a)(4) (2000 \& Supp. _ 200_); Treas. Reg. § 1.401(a)(4)-4 (as amended in 19___. See generally Langbein \& Wolk, supra note , at 326-29. 
equals or exceeds her employer's costs for her retirement benefits. ${ }^{191}$ In other words, a willing employee pays for her own retirement benefits, or pays more for her benefits than her employer spends for her benefits. ${ }^{192}$ Now we define the "reluctant employee": a reluctant employee pays an implicit price that is less than her employer's costs for her benefits. ${ }^{193}$ In other words a reluctant employee receives retirement benefits that cost more than she pays for her benefits. An employee is a reluctant employee to the extent that the cost of the benefits exceeds the implicit price that she pays. To the extent that a reluctant employee's benefits exceed her implicit price, they are referred to as "mandated benefits"; mandated benefits are retirement benefits that a plan provides to an employee to the extent that the costs of the benefits exceed the implicit price paid by the employee. ${ }^{194}$ The reluctant employee and her mandated benefits are illustrated in example 4.

\section{Example 4}

A Reluctant Employee Pays Receives More Benefits than She Pays For

Facts: Employee $\mathrm{R}$ is paid salary of $\$ 20,000$, and receives retirement benefits that cost her employer $\$ 2000$. R's market rate of total compensation is $\$ 21,200$; she pays an implicit price of $\$ 1200$ for her retirement benefits. ${ }^{195}$

${ }^{191}$ See supra note ___ and accompanying text.

192 When a willing employee pays a price that exceeds her employer's costs, the employer captures employer surplus.

193 Professor Halperin coined the term "reluctant employees" to describe employees ". . . who place a low value on tax-favored benefits ...." Halperin, Special Tax Treatment, supra note , at 18. An important reason why reluctant employees are unwilling to trade salary for retirement benefits is that they may have a strong need for current income. See generally Wolk, Discrimination Rules, supra note, at 429-34.

There is no conceptual congruity between the Code's definitions of highly and nonhighly compensated employees and our definitions of willing and reluctant employees. The Code's definitions are technical and mechanical; our definitions are purely theoretical.

${ }^{194}$ Cf. generally Bankman, Tax Policy and Retirement Income, supra note, at 806-07, and at 807 ("At some point, virtually al individuals will prefer current income to future pension benefits.")

${ }^{195} \mathrm{R}$ is receiving a compensation package that includes $\$ 20,000$ salary and $\$ 2000$ of retirement benefits. She must value this package as having a value of at least $\$ 21,200$; that is, she values retirement benefits that cost $\$ 2000$ as worth at least $\$ 1200$. This is so because if she valued the retirement benefits at less than $\$ 1200$, she would shift to a job that paid her a salary of $\$ 21,200$. Assuming that her employer does not individually adjust her $\$ 20,000$ salary to take into account any value that her retirement benefits might have to her in excess of $\$ 1200$, she might be valuing her retirement benefits at more than $\$ 1200$. In this case she would be receiving a compensation package that she values more than her market rate of compensation.

Assuming that $\$ 1200$ of retirement benefits was at R's margin for benefits, she valued 
Conclusions: $\mathrm{R}$ is a reluctant employee to the extent of the retirement benefits that are purchased with the $\$ 800$ in excess of her implicit price. ${ }^{196} \mathrm{R}$ receives mandated benefits that cost $\$ 800 .{ }^{197}$

The only reason that R's employer would provide her with retirement benefits that cost $\$ 2000$, which includes $\$ 800$ of mandated benefits, is in order to comply with the benefit allocation rules and specifically the nondiscrimination rules. ${ }^{198}$ In Example 3 we considered a willing employee, $\mathrm{W}$, who is paid a salary of $\$ 95,000$, receives retirement benefits that cost $\$ 10,000$, and pays an implicit price of $\$ 15,000$ for her benefits, which allows her employer to capture $\$ 5000$ of employer surplus. ${ }^{199}$ Assume that $\mathrm{W}$ participates in the same retirement plan as $\mathrm{R}$. On these facts, $\mathrm{W}$ is a highly compensated employee and $\mathrm{R}$, a nonhighly compensated employee. W pays for and receives retirement benefits that cost about $10.5 \%$ of her salary, which is a higher rate than the $6 \%$ rate $\mathrm{R}$ is willing to pay for. (This assumption that $\mathrm{W}$ prefers retirement benefits at a rate higher than $\mathrm{R}$ reflects the generality that highly compensated

her 1200th dollar of benefits as equal in value to the $\$ 1$ implicit price that she paid for it. However, her retirement benefits up to the 1200th dollar had values to her greater than $\$ 1$. She valued a compensation package of $\$ 20,000$ and $\$ 1200$ of retirement benefits more highly than $\$ 21,200$ of salary.

${ }^{196}$ As to the retirement benefits purchased with her $\$ 1200$ implicit price, $R$ is a willing employee. Based on her $\$ 20,000$ salary, if the plan provided her with benefits equal to $6 \%$ of her salary, the benefits would cost $\$ 1200$, and she would voluntarily trade salary for benefits up to the $\$ 1200$ level.

${ }^{197}$ In principle the compensation package that includes $\$ 20,000$ of salary plus $\$ 2000$ of retirement benefits should have a value to the employee that is greater than $\$ 20,000$ salary plus $\$ 1200$ of benefits. This would hold so long as the employee valued the $\$ 800$ of additional retirement benefits at any value greater than zero. As noted above, the example implies that the employee values the last $\$ 800$ worth of retirement benefits at less than she values $\$ 800$ of salary.

Professor Halperin characterized this result as income redistribution: "While such redistribution of income is not, in my mind, a specific goal of the tax subsidy for qualified plans, it can be viewed positively, in part because it mitigates the disparity in the distribution of the tax benefits in favor of the higher paid." Halperin, Special Tax Treatment, supra note , at 14.

${ }^{198}$ Absent the benefit allocation rules, if the employer wanted to provide $\mathrm{R}$ with additional compensation the employer would pay $\mathrm{R}$ additional salary. The fact that $\mathrm{R}$ is unwilling to pay for her last $\$ 800$ worth of retirement benefits proves that after she has received $\$ 1200$ of benefits, she prefers salary rather than additional benefits. (There might be a slight income effect that would affect this statement. If R's total compensation rose to $\$ 22,000$, she might prefer some additional retirement benefits, for example \$1250.)

${ }^{199}$ See Example 3 supra p. 
employees prefer a higher rate of retirement benefits than nonhighly compensated employees. ${ }^{200}$ ) Assuming that some disparity between the rates of $\mathrm{W}$ and $\mathrm{R}$ is permitted, hypothetically the nondiscrimination rules could require the plan to provide $\mathrm{R}$ with benefits that cost $10 \%$ of her salary. In this way, the benefit allocation rules account for the fact that $\mathrm{R}$ receives mandated benefits that cost $\$ 800$.

The case of a reluctant employee raises two questions. First, how is this case consistent with the hedonic wage theory since the employee is receiving \$2000 of retirement benefits, when her preferences would indicate that beyond $\$ 1200$ of benefits, she prefers salary? ${ }^{201}$ Second, how can an employee receive more retirement benefits than she is willing pay for with her implicit price? First, the hedonic wage theory only describes an employee's choices when she voluntarily trades salary for retirement benefits; in this example, R's employer spends the additional $\$ 800$ for retirement benefits for $\mathrm{R}$ because the benefit allocation rules require that those benefits be provided to $\mathrm{R}$. If $\mathrm{R}$ had a choice between the $\$ 800$ of mandated retirement benefits, and an additional $\$ 800$ of salary, $\mathrm{R}$ would choose the additional salary.

Second, $\mathrm{R}$ can receive $\$ 800$ of mandated benefits only if the costs of the mandated benefits are paid from employer surplus and productivity gains. ${ }^{202}$ This is because there are simply no other sources for payment of the costs of mandated benefits. Earlier we saw that the costs of retirement benefits generally must be borne by the employees who receive the benefits; by definition the costs of mandated benefits are not paid by the employee who receives the benefits. In principle and in the long run, an employer cannot shift the costs of retirement benefits to its customers or its owners. ${ }^{203}$ However, as we have seen, some employees, the willing employees, pay more for their retirement benefits than the benefits cost so that a sponsoring employer may be able to capture employer surplus. And a retirement plan might generate productivity gains that the employer is able to retain. These are the two sources of funding to pay for mandated benefits, and they are the only two sources. In the example above,

${ }^{200}$ See supra note 166 and accompanying text.

${ }^{201}$ If R preferred retirement benefits up to the $\$ 2000$ level, her employer could pay her a market rate compensation package of $\$ 19,200$ of salary and $\$ 2000$ of retirement benefits. In this case she would be a willing employee.

202 The division of employee surplus and productivity gains created by a retirement plan depends upon labor market conditions. See supra note

${ }^{203}$ See supra note and accompanying text. and accompanying text. 
the employer captured $\$ 5000$ of employer surplus from employee $\mathrm{W}$; if at least $\$ 800$ of this employer surplus can be allocated to pay for R's mandated benefits, or if the employer captures sufficient productivity gains in connection with its sponsorship of a retirement plan, then $\mathrm{R}$ can receive more retirement benefits than she pays for.

The benefit allocation rules have a real effect only when they cause a retirement plan to provide a reluctant and nonhighly compensated employee with more benefits than she is willing to pay for. The rules affect only the benefits received by nonhighly compensated employees; a plan may provide a lower level of benefits to highly compensated employees, or otherwise discriminate against highlies. The rules only affect the amount of benefits that a nonhighly compensated employee receives when the rules provide her with more benefits than can be purchased with the implicit price that she pays. Presumably many nonhighly compensated employees are willing to buy retirement benefits up to some level; to the extent that the benefit allocation rules do not require that nonhighlies receive retirement benefits in excess of this level, they have no effect. ${ }^{204}$ The benefit allocation rules have a real effect only to the extent that they cause a retirement plans to provide a nonhighly compensated employee with mandated benefits.

\section{Standardized Employee Benefits and Employee Preferences}

\section{A. Employees Choose Among Standardized Employment Packages}

The examples that have been presented so far may seem seriously unrealistic since they seem to suggest that an employee negotiates with her employer to trade certain amounts of salary for certain amounts of retirement benefits. Of course in reality only a tiny fraction of employees, those who are at the very highest levels of compensation or who have highly specialized expertise, enjoy such bargaining power. Generally employees do not have individual bargaining

${ }^{204}$ Presumably many nonhighly compensated employees are willing to pay for more or less retirement benefits since a nonhighly compensated employee may earn as much as $\$ 90,000$ or more. See supra note and accompanying text. A willing nonhighly compensated employee will receive whatever level of benefits she is willing to pay for whether or not there are benefit allocation rules. To this extent, the benefit allocation rules have no effect on the retirement benefits received by nonhighly compensated employees.

It would be possible for all of the benefits received by nonhighly compensated employees to be the result of voluntary trades of salary for retirement benefits. If the plan covers no highly compensated employees, then the benefit allocation rules do not require that any particular 
power in their dealings with a particular employer. For almost all employees, formation of an employment relationship simply means that the employee chooses to take or to leave an entire job package, including its compensation package and whatever retirement benefits may be included, on the terms offered by an employer.

The employer is the party who immediately and directly packages together all the terms of employment that will apply to a particular job. A particular employer offers all employees who will perform work of a particular type or at a given skill level approximately equal working conditions, salary, retirement benefits, other employee benefits, and other terms and elements of employment. Employment terms are standardized by job category; the standardized employment terms apply to all employees who work in a given job category. The use of standardized employment terms for various job categories implies that employment terms are determined for groups of employees.

The standardized employment terms include a compensation package, which itself will be standardized for the employees in the group. Each employee will receive salary and the same set of employee benefits, if any are included. If retirement benefits are part of the compensation package, all of the employees in the group will be covered by a retirement plan that provides each of them with uniform retirement benefits as they satisfy the conditions for benefits as specified by the plan. Of course, this is not to say that each employee earns exactly the same amount of salary; for example, it is very common for salaries to increase as an employee accumulates increasing job tenure. ${ }^{205}$ But each employee will be included in the same system of initial salary and salary increases. In general, each of the components of employees' compensation packages is standardized across groups of employees.

Employers standardize employment terms for two reasons, business considerations and legal requirements. Business considerations cause employers to voluntarily standardize their employment terms for employee groups that the employer defines. Legal requirements compel employers to standardize employment terms across legally defined groups of employees. The business considerations that cause employers to voluntarily standardize employment terms include the fact that standardized employment terms can reduce the employer's costs of

amount of benefits would have to be provided to nonhighly compensated employees.

${ }^{205}$ [CITE authority that job tenure and compensation are strongly positively related. 
contracting with employees and enable the employer to achieve efficiencies in the organization of its operations. ${ }^{206}$ Standardized employment terms also preserve the appropriate relative relationships among the amounts of compensation paid to employees who perform similar and different work. ${ }^{207}$

Legal requirements that cause standardization of employment terms include the many legal regimes that regulate different aspects of the employment relationship. Wage and hour regulation and the mandatory provision of retirement benefits through the Social Security system are two of the most widely recognized and universal systems of legal regulation of employment. And of course voluntarily provided retirement benefits are regulated by retirement plan law. We have just seen how the benefit allocation rules require that retirement benefits received by nonhighly compensated employees must be standardized so that they are at least as favorable for these employees in quality as benefits received by highly compensated employees and so that the nonhighlies receive a quantity of benefits that is reasonably comparable to the quantity received by highlies. The benefit allocation rules regulate which employees must be included in the groups that receive standardized benefits.

The standardization of employment terms affects the ways in which employees' preferences determine the contents of their compensation packages. The effects of standardization depend upon whether a particular employee benefit has been standardized voluntarily by the employer, or has been standardized in response to legal mandates. If an employer voluntarily standardized a compensation package for a group of employees that the employer defined, the standardization would have no significant effect on the contents of the employees' compensation packages; employees' preferences would control the make-up of their compensation. This is explained in section B below. However, retirement benefits are substantially standardized by the legal mandates of retirement plan law; section $\mathrm{C}$ below examines the ways in which the law does this.

Ehrenberg \& Smith, supra note, at 408. (This includes references to age relationship.)

${ }^{206}$ Standardized compensation packages are simply a particular example of the widespread practice of utilizing standardized contracts when a person engages in a large number of similar transactions, or transactions that do not individually involve a large amount of money. ${ }^{207}$ Cass R. Sunstein, ed, Behavioral Law and Economics (Cambridge U. Press 2000). 


\section{B. Voluntarily Standardized Compensation Packages}

Standardization of compensation packages that results from the voluntarily choices of employers and employees has little effect on the outcomes suggested by the hedonic wage theory. Employee preferences determine the contents of their compensation packages. Previously we have examined the two processes that cause this outcome: in designing a compensation package for a group of employees, the employer is impelled to include the components that are valued most highly by the employees who receive the package, and in selecting among alternative jobs employees sort themselves into employment that provides them with the forms of compensation that they value most highly. ${ }^{208}$ So long as an employer is free to define the group of employees that is to receive a standardized compensation package and to define the components of that compensation package, and so long as employees are free to choose among alternative jobs, employers will provide employees with the forms of compensation that they value most highly, and employees will migrate to jobs that provide them with the compensation packages that they value most highly. Employers and employees will sort themselves into employment matches that reflect the employees' preferences. Voluntary standardization of compensation packages does not limit the effects of employees' preferences. Its only effect is to cause those preferences to be expressed by, and satisfied for, groups of employees. Voluntary standardization of compensation packages means that the preferences and choices of groups of employees will control the forms of compensation that they receive.

\section{Standardized Retirement Benefits}

The same business considerations that cause voluntary standardization of compensation packages would, in the absence of legal regulation, cause some degree of voluntarily standardization of the retirement benefits that each employee received. The employer and employee sorting processes generally would enable employees to receive the levels of retirement benefits that they prefer. Employee preferences and choices expressed by groups of employees as defined by the sponsoring employer would determine the levels of retirement benefits that employee receive.

${ }^{208}$ See supra Part III.A.2. 
However, in the case of retirement benefits whatever standardization might result from business considerations is completely masked by the standardization resulting from legal regulation of the benefits. Legal regulation of retirement benefits is extensive and detailed. We have seen that under the benefit allocation rules, once one highly compensated employee receives retirement benefits, the rules regulate which nonhighly compensated employees receive

what quantity of retirement benefits, and require that the benefits must be of a uniform quality. ${ }^{209}$ In addition to the benefit allocation rules, two other portions of retirement plan law have the effect of standardizing retirement benefits across employees; these are the provisions of income tax law that govern the inclusion of compensation in an employee's gross income and the provisions that set quality standards for retirement benefits, standards that are uniform for all retirement benefits.

\section{Income Tax Law Standardizes Retirement Benefits}

The income tax rules that determine the year in which an employee must report an item of compensation for income tax purposes have the effect of forbidding retirement plans from offering participants individual choice about the amounts of retirement benefits that they receive as part of their compensation packages. This general proposition is subject to an enormously important, but limited, exception for so-called section 401(k) plans, which is discussed below. ${ }^{210}$ The general rule provides that a plan participant must include an item of compensation in her gross income if she has actual or constructive receipt of the item in the form of money. This implies that if a plan participant has a choice to receive an amount in the form of either salary or retirement benefits, then the amount must be currently included in the participant's gross income. Since exclusion of the value of retirement benefits from a participant's gross income is an explicit or implicit assumption of a retirement plan, plans may not offer a participant an individual choice to explicitly trade salary for tax consequences. ${ }^{211}$ This means that a plan must standardize the amounts or rates of contributions across groups of retirement plan participants. The benefit allocation rules require that these groups be defined so that nonhighly compensated

${ }^{209}$ See supra note 181 and accompanying text.

${ }^{210}$ See infra note 220 and accompanying text.

${ }^{211}$ For example, a defined contribution plan must provide every participant in a plan with retirement benefits that equal $5 \%$ of each participant's salary. Income tax rules in effect forbid the plan from allowing one participant an election to receive retirement benefits that equal $25 \%$ of her salary, while another participant chooses to receive benefits that equal $5 \%$ of her salary. 
employees receive benefits that are reasonably comparable to the benefits received by highly compensated employees.

Income tax law requires that an employee must include an item of compensation in her gross income (unless the compensation is received in a non-taxable form such as retirement benefits) in the taxable year in which she "receives the amount." 212 Income tax law uses two basic rules to determine the year in which an employee receives compensation: first, an amount that an employee actually receives must be included in gross income; and second, an amount that an employee constructively receives must also be included. ${ }^{213}$

212 I.R.C. $\$ 451$ (a) (2000 \& Supp. _ 200_).

213 The general and historical income tax treatment of retirement plan contributions is based on the generally applicable rules governing inclusions in gross income:

"Gains, profits, and income are to be included in gross income for the taxable year in which they are actually or constructively received by the taxpayer . ..."

Income although not actually reduced to a taxpayer's possession is constructively received by him in the taxable year during which it is credited to his account, set apart for him, or otherwise made available so that he may draw upon it at any time ...."

Treas. Reg. $\S \S 1.451-1,-2$ (as amended in 1999) (emphasis added).

When an employee actually receives salary she must include it in gross income.

Under the constructive receipt rule, even if an employee does not actually receive an amount of salary, she must include that amount in gross income if she had a right to take the amount. Subject to an important exception for so-called section 401(k) plans discussed below, if an employer gives an employee a choice to receive salary, or to receive an amount of retirement benefits, the employee must include the amount of salary that was available in gross income even if she chooses the retirement benefits. The amount of salary must be included in gross income, even if the employee applies it to the purchase of retirement benefits.

In general terms, if an employee receives salary and purchases her own retirement benefits, or if she has an option to receive salary, the amount contributed for retirement benefits will be currently taxed to the employee. The general principle is that when an employee explicitly purchases her own retirement benefits, she must pay for them with after-tax income. There are two exceptions to this principle, one of historical interest, the second of great current importance.

The exception that is of historical interest existed prior to the enactment of ERISA in 1974. Some employers had offered employees an explicit choice, exercisable prior to the earning of compensation, to contribute a portion of their future salary to a money purchase pension plan. This type of program was known as a "cash or deferred arrangement," or a "CODA." The I.R.S. had ruled that in some circumstances these employees did not constructively receive the amounts contributed to the retirement plan. [Cite ERISA effective date provision dealing with CODA's. ERISA comm. reps. on CODA's.] An artifact of this historic exception to the constructive receipt rules remains in the I.R.C.; a "pre-ERISA money purchase plan" may include a cash or 
We have noted that retirement plan law places the incidence of payment of retirement plan contributions on the sponsoring employer, notwithstanding the fact that the economic incidence of the costs of retirement benefits is on employees. Given the economic substance that employees bear the costs, the fact that employers pay the contributions might be described as simply a matter of form. However, income tax law takes this formality as the foundation for determining the income tax consequences of retirement plan contributions. ${ }^{214}$ If an employer contributes an amount to its plan on behalf of an employee, the employee may exclude the amount from her gross income (assuming all other requirements are met). ${ }^{215}$ Contrariwise, if an employee were to receive her entire compensation in the form of salary and then she were to contribute the cost of her retirement benefits to the retirement plan, she would have to include the entire salary in gross income; she would not be entitled to an exclusion or deduction for the amount contributed to the plan. ${ }^{216}$ Referring to the facts of Example 1, if employee $\mathrm{H}$ receives

deferred arrangement. I.R.C. $§ 401(k)(1)$, (6) (2000 \& Supp._200_). The status quo for CODA's was frozen in ERISA, pending Congress's enactment of a generally applicable approach.

The current exception that allows employees explicit and direct control, to a limited degree, over the proportion of retirement benefits that their compensation packages include is

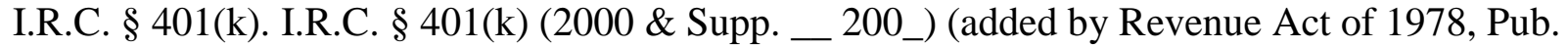
L. No. 95-600, $\S 135(\mathrm{a}), 92$ Stat. 2763, __ ). Section 401(k) allows a profit-sharing plan to include a CODA; the CODA explicitly permits an employee who is participating in the plan to choose to receive a portion of her salary either as a cash payment, or to defer that portion as an "elective deferral," which is contributed to the section 401(k) plan and credited to her participant's account. See id. $\S \S 401(\mathrm{k})(1), 402(\mathrm{~g})(3)$. Coordinate provisions provide that an employee's gross income will not include her elective deferrals, up to the specified ceiling amounts. See id. § 402(g). The employee's elective deferrals are designated as "employer contributions." See id. $\S 402(\mathrm{~g})(3)$. The amount that can be contributed to the plan pursuant to the employee's election, without current income taxation, is limited to moderate amounts that are specified in the Code. See id. $\S$ 401(a)(30), 402(g) (e.g., in 2004, elective deferrals up to $\$ 13,000$ are excluded from gross income).

${ }^{214}$ Cf. Howell v. U.S., 775 F.2d 887 (7th Cir. 1985).

215 See I.R.C. § 402(a) (2000 \& Supp.__ 200__). CITE Treas. Reg. § 1.402(as amended in 19

${ }^{216}$ See I.R.C. $\S \S 61,161,211$ (2000 \& Supp. _ 200_). The general rule is that no deduction is allowed for an employee's personal contributions to an employer-sponsored retirement plan. Langbein \& Wolk, supra note 26, at 228 ("Employee contributions generally are not deductible from the employee's gross income."). There are now exceptions to the general rule. Subject to various conditions and limitations, an employee may be allowed a personal deduction for a contribution to an individual retirement plan. See id. $\S 219$. An individual retirement plan includes an individual retirement account, and an individual retirement annuity, 
her entire \$110,000 compensation as salary, the actual receipt rule applies; the employee will be taxed on the entire $\$ 110,000$ even if she were to immediately pay $\$ 10,000$ to the retirement plan to fund her retirement benefits. ${ }^{217}$

The principle that the employee is taxed on money that she receives is not limited to money that comes into her direct and actual possession; she is also taxed on money that she constructively receives. ${ }^{218}$ If in Example 1, the employer had given $\mathrm{H}$ a choice to either receive the $\$ 10,000$ as salary or to have it contributed to the retirement plan, the fact that the $\$ 10,000$ was made available to $\mathrm{H}$ without restriction is sufficient to cause constructive receipt and current income taxation for her, even if she elects to have the $\$ 10,000$ contributed to the retirement plan. The constructively received $\$ 10,000$ is included in her income, and, in general terms, there is no deduction allowed for personal contributions to an employer-sponsored retirement plan. The constructive receipt rule implies that any amount that an employee could receive as salary will taxed to her as current salary, notwithstanding that part of the amount might be applied to purchase retirement benefits.

The practical effect of the income inclusion rules, most significantly the constructive receipt rule, is to preclude a retirement plan from offering employees an explicit choice between salary and retirement benefits (except to the limited extent specifically authorized by section $401(\mathrm{k})){ }^{219}$ Since employees may not individually choose the amount of retirement benefits that

see id. $\$ 7701(\mathrm{a})(37)$, both commonly referred to as an IRA.

${ }_{217}$ See supra note ___ and accompanying text.

${ }^{218}$ Income tax law limits the degree to which employees may be granted an explicit choice between taxable salary and non-taxable retirement benefits.

${ }^{219}$ I.R.C. § 401(k) (2000 \& Supp. _ 200_). Preclusion of individual employee choice over the amount of retirement benefits received supports the benefit allocation rules and it protects the income tax base. In the context of the benefit allocation rules, we will see that their principal effect is to limit the retirement benefits that highly compensated employees may receive. See infra note ___ and accompanying text. If highly compensated employees could individually choose to receive more retirement benefits, many of them would do so. This would cause the benefit levels of highly compensated employees to diverge from the levels of nonhighlies; it would undercut the requirement that these levels be reasonably comparable.

The income tax base would also be threatened by individual choice. As just noted, the likely effect of individual choice over retirement benefits would be that some, perhaps most, highly compensated employees would choose to receive more retirement benefits. Since these benefits are not currently taxed, the tax liabilities of highly compensated employees would be reduced.

These concerns probably account for the fact that individual choice has never been freely 
they receive, the employer and its employees may not explicitly and directly conform the amount of retirement benefits that any individual employee receives to that employee's preference. A plan must provide the same amount or rate of retirement benefits to every plan participant, or to nondiscriminatory groups of participants.

2. Limited Escape from Standardization: The Section 401(k) Plan

If the benefit allocation rules and the constructive receipt rules did not standardize retirement benefits, it is likely that many retirement plans would allow employees to explicitly choose what portion of their compensation that they would receive in the form of retirement benefits. Retirement plans would offer individual choice over the amount of retirement benefits because it would maximize the utility that the plan would provide to employees. Employees who derive the greatest utility from retirement benefits would select larger amounts of benefits; employees who derive little or no utility would choose to receive small, or no, retirement benefits. The economic substance of retirement benefit arrangements would tend toward variation in the amounts of retirement benefits that different employees receive. However, the general rules of retirement plan law seek to eliminate this natural variation and provide every employee with the same rate of retirement benefits.

Perhaps in an implicit recognition of the power of economic forces, Congress has created, and continues to expand, an exception to the general rules of retirement plan law, an exception that explicitly accommodates individual choice about retirement benefits. The exception is the section 401(k) plan. A section 401(k) plan is simply one more of the many variations of employer-sponsored retirement plans. It is a profit-sharing plan that includes a "qualified cash or deferred arrangement," a "CODA." ${ }^{220}$ As the terminology suggests, a CODA offers the plan

allowed in the selection of retirement benefits. The individual choice permitted by section $401(\mathrm{k})$ plans is accompanied by minimum requirements for benefits for nonhighly compensated employees, and is limited to statutory ceiling amounts. See infra note and accompanying text.

${ }^{220}$ See I.R.C. § 401(k)(1), (2) (2000 \& Supp.__ 200_). Profit-sharing plans that include a CODA are known as "section 401(k) plans"; these plans are widely adopted and they are the fastest growing type of retirement plan.

CITE. EBRI Research Highlights: Retirement Benefits (Employee Benefit Research Institute Special Report SR-42, Issue Brief No. 258, June 2003). [This has data on types of plan, and cites to more detailed ERBI data].

[CITE. Include reference to $\S 403$ (b) plans, which operate similarly to section 401(k) 
participant an explicit election to either receive part of her compensation as salary or to have that part contributed to her employer's section 401(k) plan. To the extent that the employee elects to receive salary, it is included in her gross income. If the employee elects to defer a portion of her salary, the employer contributes the deferred portion to the section 401(k) plan; the deferred portion is excluded from the employee's gross income up to statutorily specified ceiling amounts. $^{221}$ As a matter of income tax doctrine, the essential element of a section 401(k) plan is its limited exception to the constructive receipt principle; this exception allows a participant to choose to receive salary currently or to contribute a portion of that salary to a retirement plan without current income taxation of the deferred amount. ${ }^{222}$ A section $401(\mathrm{k})$ plan credits a participant's elective contribution to the employee's account in the retirement trust, and it will ultimately be paid to her as retirement income. ${ }^{223}$ With section 401(k) CODA election, an employee individually and explicitly trades a portion of her employee's salary for retirement benefits; the explicit price of the retirement benefits is the amount of forgone salary. ${ }^{224}$

Section $401(\mathrm{k})^{225}$ does not completely abandon the benefit allocation rules. A section 401(k) plan must meet all the requirements of retirement plan law that apply to a profit-sharing plan, except section $401(\mathrm{k})$ includes special, relaxed nondiscrimination rules. ${ }^{226}$ In other words, all of the generally applicable benefit allocation rules apply to a section 401(k) plan, except there are special rules to determine the degree to which highly compensated employees may receive larger retirement benefits than nonhighly compensated employees. The least demanding of the special nondiscrimination rules allows a section $401(\mathrm{k})$ plan to qualify if the employer pays a non-elective contribution of at least $3 \%$ of each participating employee's compensation to the

plans, and are available to employees of employer that are non-profit organizations.]

${ }^{221}$ See I.R.C. $\$ \S 401(\mathrm{a})(30), 402(\mathrm{~g})(1)(2000 \&$ Supp. _ 200_) (e.g., in 2003, elective deferrals up to $\$ 12,000$ are excluded from gross income). In a completely counter-intuitive definition, the employee's elective deferrals are designated as "employer contributions." See id. $\S$ 402(g)(3), (3)(A) ("[T]he term 'elective deferrals' means . . any employer contribution . . . to the extent not includible in gross income ....").

${ }^{222}$ See I.R.C. $\S 402(\mathrm{e})(3)$ (2000 \& Supp. _ 200_).

${ }^{223}$ See id. $\S \S 401(\mathrm{k})(1), 402(\mathrm{~g})(3)$.

${ }^{224}$ Because the participant explicitly trades a portion of her current salary for retirement benefits, a section 401(k) CODA election represents a perfect implementation of the theoretical trade-off between salary and retirement benefits.

${ }^{225}$ I.R.C. $\$ 401(\mathrm{k})$ (2000 \& Supp. __ 200_).

${ }^{226}$ See I.R.C. $§ 401(k)$ (2000 \& Supp. _ 200_). 
plan. ${ }^{227}$ In other words, if a section $401(\mathrm{k})$ plan provides a standardized contribution of $3 \%$ of compensation for all participants, the balance of contributions for each participant, up to a 2004 statutory ceiling of $\$ 13,000$, may be entirely voluntary on the part of the participant. ${ }^{228}$

A section 401(k) plan is the type of retirement plan that conforms most closely to the economic substance of the retirement benefits relationship that exists between an employer and an employee. The hedonic wage model suggests that the utility that each participant will derive from her retirement plan contributions controls the amount of salary that the participant is willing to trade for retirement benefits. Assessments of the utility provided by retirement benefits vary across plan participants, and they shift for each participant over time. Left to voluntary choice, different plan participants would select widely varying proportions of their salary to contribute to a plan, and each plan participant would likely select different proportions at different points in her working life. The section $401(\mathrm{k})$ plan is the only type of retirement plan that accommodates these choices. Section 401(k) plans also happen to be the fastest growing type of retirement plan. Perhaps the popularity of section $401(\mathrm{k})$ plans may be accounted for by the fact that they allow the parties' formal arrangement to converge more closely with the economic reality.

A section 401(k) plan also makes totally transparent to both employer and employee that the employee bears the cost of her retirement benefits to the extent they have been funded by her own elective deferrals. ${ }^{229}$ Even in a section $401(\mathrm{k})$ plan the incidence of payment of plan contributions remains on the employer; when an employee elects to defer part of her salary in exchange for retirement benefits, the employer retains the deferred salary and the employer must pay it directly to the section 401(k) plan. Notwithstanding this formality, both employers and employees clearly understand that the employee bears the incidence of cost of the benefits because of the direct, one-for-one relationship between the amount of the employee's deferred salary and the increase in her accrued benefits in the retirement plan. This transparency is valuable to both employers and employees. If an employer mistakenly believes that it bears the costs of retirement benefits for its employees, then it may fail to provide the benefits that some employees would value highly because of a fear that the employer's costs would become uncompetitive. Conversely, if employees mistakenly believe that by persuading their employer to

\footnotetext{
${ }^{227}$ See I.R.C. $\$ 401(\mathrm{k})(12)(\mathrm{C})$ (2000 \& Supp. _ 200_).

${ }^{228}$ I.R.C. $\S 402(\mathrm{~g})(1)(\mathrm{B})$ (2000 \& Supp. __ 200__).

${ }^{229}$ See id. $\S 402(\mathrm{~g})(3)$.
} 
provide retirement benefits they have absolutely increased their compensation, the employees might demand larger retirement benefits than they would pay for if the costs of those benefits were explicitly apparent to them. By obscuring the true incidence of cost of retirement benefits, retirement plan law might cause some employees to receive smaller retirement benefits than they might prefer and might cause other employees to receive retirement benefits that are too large. By making explicit the fact that the employee pays for her own retirement benefits, a section 401(k) plan enables the parties to reach agreements that most closely conform to the employees' preferences.

\section{The Qualitative Regulation of Retirement Benefits}

In addition to regulating the quantity of retirement benefits that employees receive, retirement plan law regulates the quality of those benefits by setting minimum standards for the terms and conditions that comprise the retirement benefits rights and for the procedures by which the plan administers these rights. ${ }^{230}$ The objective of qualitative regulation is to increase the likelihood that an employee will actually receive the retirement income payments that are promised to her during her working years. ${ }^{231}$ Benefits are of higher quality when the participant has a higher likelihood of actually receiving retirement income payments. Actual payment of retirement benefits may be a somewhat special legal problem because of the extremely long performance period that can inhere in the promise of retirement benefits; if an employee earns retirement benefits when she is twenty-five years old and if she later receives payment of those benefits as periodic retirement income payments extending until she is eighty-five years old, or older, sixty or more years could elapse between the initial promise of retirement benefits and completion of the promisor's performance. As the period for performance of the retirement benefits promise extends, sources of risk of nonperformance multiply. ${ }^{232}$ Retirement plan law reduces risks of nonperformance by setting mandatory terms that exclude some of the sources of these risks. $^{233}$

${ }^{230}$ Coverage, participation, amounts of benefits, uniformity of benefits among participants, accrual and vesting of benefits, spousal interests in benefits, and payment of benefits all must conform to the specifications set out by retirement plan law.

${ }^{231} C f$. Langbein \& Wolk, supra note, at 121 ("The central problem to which ERISA is addressed is the loss of pension benefits previously promised.").

${ }^{232}$ See Langbein, What ERISA Means by “Equitable," supra note 26, at 1322.

${ }^{233}$ Cf. Langbein, What ERISA Means by “Equitable," supra note 26, at 1322 ("ERISA 
Like the benefit allocation rules, much of the regulation of the quality of retirement benefits is implemented by rules that specify the substantive content of a retirement plan document, thus indirectly controlling participants' entitlements. ${ }^{234}$ For example we earlier noted that a retirement plan must define retirement benefits so that they are nonforfeitable after an employee has completed seven years of service. ${ }^{235}$ Obviously this mandatory term eliminates the risk that an employee could forfeit her retirement benefits because of termination of her employment after she had completed seven years on the job. An example of regulation of the administration of employees' retirement benefit rights is the ERISA provision that requires that every retirement plan include a procedure for the review of benefit claim denials. ${ }^{236}$ This reduces the risk that a participant might be paid less retirement income than she was actually entitled to receive. To the extent that retirement plan law successfully reduces various elements of risk of nonperformance in the payment promise of retirement benefits, it provides employees with higher quality retirement benefits.

Regulation of the quality of retirement benefits standardizes retirement benefits both across retirement plans and across participants in a single plan. The minimum quality standards for retirement benefit rights apply to all private sector, for-profit employers, so there is little variation in the nature of employees' retirement benefit rights across employers. Within a single plan, the terms and conditions of the retirement benefits provided to nonhighly compensated employees must be at least as favorable to these participants as the terms and conditions of benefits provided to highly compensated employees. This results in uniform terms and conditions for all the retirement benefits that the plan provides. ${ }^{237}$ When a quality standard is set,

was primarily designed to protect pension plan participants and beneficiaries against two hazards, default risk and administration risk ....")

${ }_{234}$ See supra note __ and accompanying text.

${ }^{235}$ See I.R.C. $\S 41 \overline{1(\mathrm{a})(2)(B)}(2000 \&$ Supp. _ 200_); ERISA $\S$ (2000 \& Supp. 20__); supra note ___ and accompanying text. ${ }^{236}$ ERISA $\S 503,29$ U.S.C. $\$ 1133$ (2000 \& Supp. 20_).

${ }^{237}$ There is no reason for a plan to provide highly compensated employees with retirement benefits on terms lessfavorable than the terms provided to nonhighly compensated employees. As we will see, the effect of legally mandated standardization of the quality of retirement benefits is to increase the price of retirement benefits. See infra note and accompanying text. Since highlies are generally willing to pay higher prices for retirement benefits than nonhighlies, there is no reason to offer highlies less expensive, lower quality benefits. Aside from the absence of demand for lower quality retirement benefits for highlies, it is more efficient for a plan to provide uniform benefits to all participants because of 
that standard will apply to all participants in a plan. The close qualitative regulation of retirement benefits implies that the benefits are highly standardized.

D. Standardization of Retirement Limits Their Value and Raises Their Price

Retirement plan law imposes mandatory quality standards on retirement plans. These rules result in widespread standardization of retirement benefits on the terms specified by the quality standards. This standardization limits the potential value that can be created by a retirement plan and it increases the price that must be paid by employees for their benefits. The value of retirement benefits is limited because standardization of retirement benefits limits the spectrum of choices across which employees' preferences for retirement benefits may range. When retirement plan design is standardized, many possible alternative designs that might add value are foreclosed to the parties. From the definition of the group of employees covered by the plan, to the ultimate payment of retirement income, retirement plan law closely regulates how retirement plans operate.

If retirement plan law imposed lesser, or no, regulation on the terms and conditions that comprise retirement benefits, an employer would define the groups of employees who would receive retirement benefits, it would tailor the terms and conditions of the benefit rights, and it would provide the levels of benefits, all so as to respond as fully as possible to the preferences of the employees in each group. Depending on the employer and employees, the retirement benefits might be offered on an elective basis so that employees could individually choose their level of benefits. ${ }^{238}$ Across employers there might be a range, perhaps wide, in the qualitative aspects of the retirement benefit rights. For example, for an employer that could enhance productivity by encouraging long job tenures, retirement benefits might remain forfeitable for a substantial period. For an employer that anticipated a high rate of turnover among employees who earned high incomes, large retirement benefits that were fully vested at all times might be most efficient. ${ }^{239}$ Employees' preferences would determine whether or not employees received simplification of administration.

${ }^{238}$ This of course is the model that a section 401(k) plan implements. An employer would specify a level of retirement benefits if it wanted to use the retirement plan as a device to bond the employee to the employer. See supra note and accompanying text.

${ }^{239}$ High income employees would generally value retirement benefits because of their tax exemption, and fully vested benefits would allow these employees to purchase retirement 
retirement benefits, the amounts of benefits that a group of employees received, and the nature of the benefits. By tailoring its plan to the preferences of the participating employees, the sponsoring employer could add the maximum possible value. Employees could buy exactly the retirement benefits that they were willing to pay for.

Standardization of retirement benefits raises the price of the benefits because it increases the costs of providing retirement benefits to employees. There are two types of cost increases, the costs of retirement benefit payments that would not have been made in the absence of qualitative regulation, and increased administrative costs. The costs associated with mandated vesting illustrate the former; costs of review of claims denials, the later. The minimum vesting standards of retirement plan law provide a clear example of how quality standards increase the amounts of retirement benefits paid to participants, and thereby raise the price of a unit of retirement benefits. Consider an example of a transition from slower vesting to more rapid vesting as mandated by law. If a retirement plan is to maintain the same level of retirement benefits for employees who vested under an older system with longer-deferred vesting, additional contributions must be made to the plan. All the longer-tenure employees who vested under prior rules also vest under the more rapid vesting rules. Some employees who forfeited retirement benefits under the old rules receive benefits under the new rules. Thus, holding benefits for the longer-tenure employees constant, additional costs are incurred for the benefits for employees who vest under the new rules. ${ }^{240}$

The requirement that a retirement plan provide a procedure for review of benefit claim denials illustrates how standardization of the administration of retirement benefits increases costs. In general, the provision of retirement benefits to employees is more costly than simply paying salary. ${ }^{241}$ Administering the payment of retirement income involves costs, including the

benefits without taking on the high risk that they would forfeit the benefits. See supra note and accompanying text.

240 Alternatively, the rate of benefits for all employees could be reduced so that the same absolute amount of benefits would be distributed under the rapid vesting provisions. In this case longer-tenure employees (who would have vested under the slower vesting provisions) would receive reduced benefits; if the implicit prices that they paid stayed constant, a benefits reduction is equivalent to a price increase for the benefits that remain. When benefit rates are reduced in connection with an acceleration of vesting, an initial effect can be a reallocation of retirement benefits from longer-tenure employees to shorter-tenure employees. Id.

${ }^{241}$ When an employer and employee agree that part of compensation will be paid as 
costs of determining when a plan participant is entitled to receive payments and the amounts of the payments. Creation of a retirement plan necessarily involves the costs of an initial determination that retirement income is due to a particular participant. When retirement plan law requires a review, essentially a second consideration, of that determination, additional costs will be incurred.

Legislated quality standards for retirement benefits necessarily decrease the value of retirement benefits or increase the costs of providing benefits to employees. In the absence of legal regulation of retirement benefits, employers would strive to provide the retirement benefits to employees that deliver the maximum value that could be purchased with implicit prices paid by employees. ${ }^{242}$ If a particular substantive term or administrative practice could provide added value to participants without increasing costs, employers, or at least the employers that provide the best compensation packages, would voluntarily adopt the term or practice. Even terms or practices that increase costs would be implemented when the value added by the provision exceeded its costs. Retirement plans would evolve to provide employees with the retirement benefits that they value most highly and that can be purchased with the employees' implicit prices. In general all retirement plan provisions and practices that can add value are adopted by employers voluntarily. Legislatively mandated quality standards cannot improve this state and can only degrade it. Since value-adding retirement plan elements are adopted voluntarily, any element that can be implemented only by mandatory legislation must necessarily provide less value for the sponsoring employer and plan participants than it costs. The mandatory standardization of the quality of retirement benefits leads to benefits to which employees assign lower values or for which higher prices must be charged.

\section{The Limitations of Retirement Plan Law}

A. Qualitative Standardization Prices Lower-paid Employees out of the Retirement Plan System.

When retirement plan law mandates standardization of the quality of retirement benefits, the ultimate effect of the law is to price some lower-paid employees out of the private retirement

retirement benefits, there must be gains sufficient to cover these increased costs. See supra text following note 143 . 
plan system. Mandatory regulation of retirement benefits either reduces the value of the benefits or increases their price. Lower-paid employees generally have weaker preferences for retirement benefits than higher-paid employees and thus are more price-sensitive. ${ }^{243}$ When the value of retirement benefits declines in relation to their price, employees will respond by reducing or ceasing their purchases of benefits; the magnitude of this effect will be greatest among lowerpaid employees. Regulation of the quality of retirement benefits reduces the amounts of benefits that employees buy and, most significantly, the amounts bought by lower-paid employees. This is the first limitation of retirement plan law: standardization of the quality of retirement benefits prices lower-paid employees out of the retirement plan system.

Consider how legally mandated rapid vesting affects employees who might participate in a retirement plan. If retirement plan law did not require rapid vesting, prospective employees would have a choice between less expensive retirement benefits with longer-deferred vesting, or more expensive benefitswith rapid vesting. ${ }^{244}$ When a prospective employee considers an offer of employment, she typically would not know how long she might stay with the employer. In the face of this uncertainty, an employee might prefer to buy the less expensive retirement benefits. If she left the job prior to vesting, she would forfeit her benefits, but she would have paid less for them; if she stayed for a substantial fraction of her potential working years, she would receive full benefits. Another prospective employee, perhaps one more adverse to the risk of forfeiture, might choose a job that offered rapidly vested retirement benefits albeit at a higher price. It is not obvious that more expensive, rapidly vested benefits are the better choice for every employee.

Even if it were obvious that more expensive, rapidly vested retirement benefits were the better choice for almost all employees, and were sufficiently better to justify the prohibition on long-deferred vesting, the policy decision that Congress faces is not simply between these two forms of retirement benefits. In a system of voluntary job selection and voluntary retirement plans, the decision is between permitting employees to choose along a range of various types of retirement benefits, from inexpensive and risky benefits to expensive and more secure benefits, or mandating that the only type of benefits that employees may buy are the expensive benefits.

${ }^{242}$ See supra note and accompanying text.

${ }^{243}$ See supra note $\overline{166}$ and accompanying text.

${ }^{244}$ From an employee's perspective, she pays a lower price for retirement benefits with longer-deferred vesting reflecting the heightened risk that the benefits might be forfeited. 
Since lower-paid employees are more likely to buy the inexpensive benefits, the elimination of this alternative prices some lower-paid employees out of the retirement plan system. Only higher-paid employees who are willing to pay the higher price for higher quality benefits continue to participate in employer-sponsored retirement plans.

Most retirement plan scholarship seems uninterested in the costs associated with protecting employees' retirement benefit rights. ${ }^{245}$ Perhaps this stems from the appearance that the sponsoring employer pays the costs of retirement benefits; if it is believed that the costs of benefits incide on the employer, then it appears that added protection for employees' rights simply shifts wealth from the employer to employees, a shift which has great sympathetic appeal. However, the appearance deceives. Employees bear the costs of their retirement benefits. This means that retirement plan law cannot improve employees' perceived welfare because it cannot mandate terms and conditions for retirement benefits that provide a net increase in the value of the benefits as perceived by employees. It has been argued that employees might systematically err by assigning too low a value to their retirement benefits and that these errors justify legal intervention to regulate the quality (and quantity) of retirement benefits that employees receive. However, even if the Congressional choices about the content of retirement benefits are in some paternalistic sense correct, in our voluntary retirement plan system, the legal mandates will not cause employees to purchase higher quality retirement benefits than they want. Because

${ }^{245}$ See, e.g., Langbein, What ERISA Means by “Equitable," supra note 26, and the articles that Professor Langbein cites in his note 15. Id. at 1320. In his article Professor Langbein argues that the Supreme Court should reverse its long-standing interpretation of ERISA remedy provisions and should allow an individual participant to recover consequential damages for a plan fiduciary's breach of duty. Professor's Langbein's project is focused on the proper textual and historical interpretation of ERISA's statutory language. Nonetheless, the article makes no direct reference to the fact that an expansion of legal remedies available under ERISA would increase the costs of employee benefit plans. The article does footnote in another context the Supreme Court's recognition of the need to balance the protection of plan participants with increased costs:

"“[C]ourts may have to take account of competing congressional purposes, such as Congress' desire to offer employees enhanced protection for their benefits, on the one hand, and, on the other, its desire not to create a system that is so complex that administrative costs, or litigation expenses, unduly discourage employers from offering welfare benefit plans in the first place.' Varity Corp. V. Howe, 516 U.S. 489, 497 (1996)."

Id n. 63 at 1328 . 
employees' choices to buy retirement benefits are ultimately voluntary, they will not purchase retirement benefits that they value less highly than the cost of the benefits.

\section{B. The Benefit Allocation Rules Have No Effect on Some (Most?) Plans}

The benefit allocation rules are intended to cause retirement plans to provide nonhighly compensated employees with more retirement benefits than those employees would buy for themselves. These rules have an actual effect only when they require a plan to provide mandated benefits to reluctant nonhighly compensated employees. ${ }^{246}$ This occurs only when both nonhighly and highly compensated employees participate in the same retirement plan and the highlies buy retirement benefits at a higher rate than the rate that nonhighlies are willing to buy. Of course, this is generally assumed to be the typical situation since higher-paid employees generally are willing to buy higher levels of retirement benefits than lower-paid employees generally are.

Even though, in general, higher-paid employees prefer to purchase higher levels of retirement benefits than lower-paid employees, this does not imply that the highly and nonhighly compensated employees that participate in any particular retirement plan will reflect the average preferences of highlies in general and nonhighlies in general. If the nonhighlies who participate in a particular plan are willing to pay for a level of retirement benefits that is reasonably comparable to the level preferred by the highlies who are in the plan, the benefit allocation rules have no real effect. ${ }^{247}$ This might occur if the nonhighlies in the plan prefer a high level of benefits relative to all nonhighlies; call these nonhighlies "thrifty nonhighlies." It might also occur if the highlies in the plan prefer an atypically low level of benefits. When the nonhighlies and highlies who participate in a given plan are willing to purchase retirement benefits at the same rate, we can say that these participants have homogeneous preferences for retirement benefits. This brings us to the second limitation of retirement plan law: when the participants in a retirement plan have homogeneous preferences for retirement benefits, the benefit allocation rules have no effect on the amounts of benefits received by nonhighly compensated employees.

${ }^{246}$ Remember that mandated benefits can be provided to reluctant employees only when the employer has captured employer surplus or has retained productivity gains. See supra note 202 and accompanying text.

${ }^{247}$ In this plan, all employees simply receive the retirement benefits that they pay for; nonhighly compensated employees do not receive any mandated benefits. 
The case of a retirement plan that covers employees with homogeneous preferences is anything but anomalous. In fact, the hedonic wage theory predicts that retirement plans will cover groups of employees with homogeneous preferences so long as certain conditions prevail: employees must be mobile, among nonhighlies there must be a sufficient proportion of thrifty nonhighlies, and employees must have available to them a sufficient range of alternative retirement benefits rates, which requires that employers offer a sufficient range of compensation packages. In other words, the market for retirement benefits must be sufficiently thick, with enough buyers with varying preferences and sellers with varying offers so that a range of alternative rates of retirement benefits is available. When the market is thick, employees sort themselves into retirement plans that provide them the amounts of retirement benefits that they prefer; ${ }^{248}$ to the extent that this occurs, the preferences of each group of employees covered by a retirement plan are homogenous and the benefit allocation rules do not provide nonhighly compensated employees with enhanced retirement benefits.

In fact, the levels of retirement benefits offered do vary significantly among employers. ${ }^{249}$ This is to be expected since the benefit allocation rules in no way constrain variation in levels of retirement benefits across unrelated employers; the rules apply only within the group of employees that are employed by a single employer. Each separate employer can provide its employees with the level of retirement benefits that these employees prefer. ${ }^{250}$ The $^{2}$ diverse preferences of different groups of employees will be reflected by the retirement plans that their employers sponsor, or do not sponsor, for them. With diverse levels of retirement benefits available to them, employees will be able to find employment that provides them with the level of retirement benefits that they are willing to pay for. The sorting process results in some groups of employees receiving higher rates of retirement benefits and other groups receiving lower rates or no benefits. Each employer's retirement plan will tend to cover a group

248 See supra note ___ and accompanying text.

${ }^{249}$ Fifty-four percent of employees working in finance, insurance, and real estate are covered by a retirement plan, while only $29 \%$ working in retail trade are covered. Receipt of retirement benefits varies significantly across different employers along several dimensions. See Langbein \& Wolk, supra note 26, at 26-27.

${ }^{250}$ There is one part of the benefit allocation rules that imposes a minimum benefit requirement that is uniform across unrelated employers: if an employer sponsors a defined benefit plan that is top-heavy, the plan must provide each participant who is a non-key employee with a statutorily defined minimum benefit. See I.R.C. § 416(c)(1) (2000 \& Supp. __ 200_); see 
of employees with homogeneous preferences. Thus, it seems likely that the benefit allocation rules have very little real effect on the levels of retirement benefits received by nonhighly compensated employees. The diversity of levels of retirement benefits among employees confirms the theory that employees control their own retirement benefits.

Even though it seems that the benefit allocation rules generally have little impact on the actual levels of benefits received by nonhighly compensated employees, do consider the one set of conditions that must exist in order for these rules to actually enhance the retirement benefits received by nonhighly compensated employees. The benefit allocation rules might enhance nonhighlies' retirement benefits when a single employer finds it most efficient to employ a combination of both nonhighly and highly compensated employees and the employer's highlies buy retirement benefits at a rate higher than the rate voluntarily bought by nonhighlies. ${ }^{251}$ Since this is the prototypical case that is used to justify the benefit allocation rules, it is important to consider how realistic this combination of conditions is. The first condition, that an employer employs a combination of nonhighly and highly compensated employees, describes most employer's workforces. This condition itself is realistic, but in a moment we will see that employers usually can change the proportions of nonhighlies and highlies that they employ and that in some cases these changes can have detrimental impacts on nonhighlies.

The second condition requires that an employer's highlies buy retirement benefits at a higher rate than the nonhighlies would voluntarily buy; in other words, a retirement plan would cover a group of employees who have heterogeneous preferences. ${ }^{252}$ Of course this condition is inconsistent with the employee sorting process that in theory yields retirement plans that cover employees with homogeneous preferences. Sorting could be frustrated if there are too few thrifty nonhighlies. Suppose that $100 \%$ of all highlies prefer to buy retirement benefits that cost $25 \%$ (or more) of their salaries, while only $10 \%$ of all nonhighlies will buy retirement benefits that cost

generally supra note

${ }^{251}$ In general terms, the benefit allocation rules require that a retirement plan cover all employees of the sponsoring employer and that the plan provide nonhighlies with retirement benefits at a rate that is reasonably comparable to the rate provided to highlies. See supra note and accompanying text.

${ }^{252}$ For simplicity, "heterogeneous preferences" refer to the preferences of a group of employees in which the highlies prefer a higher rate of benefits than the nonhighlies. Of course employees' preferences would also be heterogeneous if highlies preferred a lower rate of benefits than nonhighlies, but this case is trivial. 
$25 \%$ their of salaries. Given this pool of potential employees, the particular combination of nonhighlies and highlies employed by an employer might result in a workforce that includes employees with heterogeneous preferences for retirement benefits, and the employer's retirement plan might cover some nonhighlies who are unwilling to buy retirement benefits at the same rate preferred by the highlies. On these facts, the nonhighlies might receive some mandated benefits unless the employer adjusted its retirement plan or the proportion of nonhighlies and highlies in the workforce.

An employer might adjust its business operations in order to reduce the proportion of nonhighlies in its workforce. In most industries to some extent nonhighly and highly compensated employees can be substituted for each other and capital investments may be substituted for some employees from either category. ${ }^{253}$ The requirements of the benefit allocation rules can influence an employer's decisions about the proportion of nonhighlies and highlies to include in its workforce and the proportion of labor and capital to use. Professor Bankman analyzed some of these effects; he concluded that the benefit allocation rules have a variety of effects depending on different assumptions. ${ }^{254}$ Under certain assumptions, the rules will cause employers to substitute highlies for nonhighlies, or capital for nonhighlies; under other assumptions, the rules cause the substitution of nonhighlies for highlies. ${ }^{255}$ To the extent that the benefit allocation rules do cause an employer to substitute away from employment of nonhighlies, the disemployed nonhighlies will obviously receive no retirement benefits from the affected employer. In this case, the benefit allocation rules decrease the retirement benefits of nonhighlies rather than increase them.

In summary, the theory of employee control of their retirement benefits predicts that generally employees sort themselves into a workforce that has homogeneous preferences for retirement benefits and, therefore, the benefit allocation rules will have no effect on the retirement benefits received by nonhighlies. However, if there are cases in which an employer's workforce has heterogeneous preferences, under some assumptions the benefit allocation rules might enhance the retirement benefits of some nonhighlies. Under other assumptions, the rules

${ }^{253}$ Joseph Bankman, The Effect of Anti-Discrimination Provisions, supra note 26, at 605. ${ }^{254} \mathrm{Id}$.

${ }^{255} I d$. at $605-10$. 
can lead to a reduction in employment of nonhighlies; in these cases, the rules reduce the retirement benefits received by nonhighlies.

\section{By Themselves, the Benefit Allocation Rules Reduce Retirement Benefits}

The preceding section described the single set of conditions in which the benefit allocation rules might enhance the retirement benefits received by nonhighly compensated employees; that is when an employer employs a workforce with heterogeneous preferences for retirement benefits and the nonhighlies receive mandated benefits. Nonhighlies receive mandated benefits only if an employer has captured some employer surplus and productivity gains. ${ }^{256}$ In order to better understand how the benefit allocation rules affect participants in a retirement plan, consider a plan that covers participants who have heterogeneous preferences, but let us assume that there is neither employer surplus nor productivity gains to pay for mandated benefits. In other words, consider the effects of the benefit allocation rules alone. (In the next section we will consider the effects of combining the benefit allocation rules with employer surplus and productivity gains.) Without employer surplus or productivity gains, the benefit allocation rules do not increase the retirement benefits received by nonhighly compensated employees, but they do decrease the benefits received by highly compensated employees. This is the third limitation of retirement plan law: in the absence of employer surplus or productivity gains, the benefit allocation rules reduce aggregate retirement benefits.

The theory of employee control of retirement benefits explains why the benefit allocation rules by themselves cannot increase the levels of retirement benefits received by nonhighly compensated employees unless there is employer surplus or productivity gains to pay for the benefits. Without employer surplus or productivity gains, nonhighly compensated employees receive only the retirement benefits that they agree to pay for. This is because a nonhighly compensated employee (really, any employee) will not choose employment with an employer that offers her a level of benefits higher than the level she is willing to pay for. ${ }^{257}$ If one employer's implicit price and benefits level were higher than a particular employee prefers, the employee would select employment with another employer that offered a lower level of

${ }^{256}$ See supra note and accompanying text.

257 This assumes that the employment and retirement benefits markets are sufficiently thick. See supra note and accompanying text. 
retirement benefits. In a voluntary retirement plan system, legal rules cannot compel employees to buy more retirement benefits than they want to pay for. ${ }^{258}$ The benefit allocation rules alone cannot increase the amounts of retirement benefits received by nonhighly compensated employees.

Assuming that in a retirement plan with participants with heterogeneous preferences the nonhighly compensated employees will prefer lower rates of retirement benefits than highly compensated employees, the benefits preferences of the nonhighlies will determine the rates of benefits received by all participants in the plan. The benefit allocation rules, particularly the nondiscrimination rules, forbid a plan from providing highlies with a higher rate of retirement benefits than it provides to nonhighlies (except for the amount of any permitted disparity). The nonhighlies purchase retirement benefits at the rate that they are willing to pay for, but the plan cannot permit the highlies to purchase retirement benefits at some higher rate that the highlies would be willing to pay for. In this way the benefit allocation rules decrease the rate of benefits of highlies below their preferred rate. ${ }^{259}$ This effect is illustrated in Example 5.

\section{Example 5}

By Themselves, the Benefit Allocation Rules Reduce Retirement Benefits

Facts: A retirement plan provides benefits the three employees, a highly compensated employee, $\mathrm{H} 2$, and two nonhighly compensated employees, $\mathrm{N} 2$ and N3. N2 and N3 purchase retirement benefits that cost $6 \%$ of their salary.

The maximum permitted disparity in benefit rates between nonhighly and highly compensated employees is 4 percentage points.

$\mathrm{H} 2$ would prefer to purchase retirement benefits that cost $15 \%$ of her salary.

${ }^{258}$ Cf. Bankman, Tax Policy and Retirement Income, supra note , at 829 ("The [nondiscrimination rules] ... [force] the working poor to purchase pension benefits they do not wish to purchase and may feel they cannot afford.") This article proposes a different interpretation of the benefit allocation rules including the nondiscrimination rules. If the working poor have an employment alternative that offers them all salary and no retirement benefits, they will shift to that employment; in this case, the benefit allocation rules cannot force them to buy retirement benefits.

${ }^{259}$ Cf. Joseph Bankman, Tax Policy and Retirement Income, supra note , at (arguing that when an employer has $1 / 2$ nonhighly compensated employees and $1 / 2$ highly compensated employees, the retirement plan will provide retirement benefits that are the average of these two groups preferences). 
Conclusions: The benefit allocation rules forbid the plan from providing $\mathrm{H} 2$ with benefits that cost more than $10 \%$ of her salary. In effect, the preferences of $\mathrm{N} 2$ and $\mathrm{N} 3$ have determined the benefit rate for $\mathrm{H} 2$.

While the intent of the benefit allocation rules is to place a floor under the benefit levels of nonhighly compensated employees, their actual effect is instead to set a ceiling in each retirement plan on the benefit levels of highly compensated employees. Fundamentally this example is an application of the theory of employee control of their retirement benefits; the benefit allocation rules cannot compel nonhighlies to buy more benefits than they are willing to pay for.

\section{The Effects of the Benefit Allocation Rules Are Weak}

Although it appears that in most retirement plans the benefit allocation rules do little to actually increase the levels of retirement benefits received by nonhighly compensated employees, consider the case in which the rules could enhance the nonhighlies' benefits. After all, this is the case that is cited to justify the enormous bulk and complexity of the benefit allocation rules. The rules enhance the retirement benefits of nonhighlies only when a retirement plan covers employees who have heterogeneous preferences and the plan provides some nonhighly compensated employees with mandated benefits. Mandated benefits can be funded only from employer surplus or productivity gains. A number of factors suggest that for most retirement plans only small amounts of employer surplus and productivity gains will be available and that nonhighlies will receive only small increases in benefits. This is the fourth limitation of retirement plan law: even if the benefit allocation rules do enhance the retirement benefits of some nonhighly compensated employees, the increases in benefits are very small.

The first reason that the benefit allocation rules have at best only a weak effect is that employer surplus and productivity gains are likely to be small in comparison to the total cost of the benefits that the plan provides. Only the retirement benefits provided to willing employees can create employer surplus. ${ }^{260}$ In addition, productivity gains probably arise largely if not entirely from retirement benefits provided to willing employees. Remember that the only reason that mandated benefits are provided to reluctant employees is because they are unwilling to pay a

${ }^{260}$ See supra note 139 and accompanying text. 
price that equals the costs of the benefits; this evidences that the reluctant employees place a low valuation on the benefits and therefore reluctant employees receive little value from the receipt of the benefits. When reluctant employees disvalue or disregard mandated benefits, the benefits will create small or no productivity gains. For example, productivity gains can result from longer job tenures; however, a retirement plan is unlikely to increase the job tenure of a reluctant employee by providing her mandated benefits that she does not much value. Thus, generally retirement benefits add value for an employer and its employees only when the benefits are provided to willing employees. Retirement benefits provided to reluctant employees are more or less wasted (in the sense of creating little or no current perceived value for the employee). Of the total costs of a retirement plan, only the costs of benefits for willing employees have the potential to create employer surplus and productivity gains.

The retirement benefits that are provided to willing employees will yield employee surplus that is just a fraction of the costs of the benefits. In Example 2 employee $\mathrm{H}$ received retirement benefits that cost $\$ 10,000$ and she valued them at $\$ 14,300$ based on her $30 \%$ tax rate. $^{261}$ Based on H's valuation of her benefits, the retirement plan generated a surplus of $\$ 4300$, or $43 \%$ of the cost of the benefits. However, that example involved a clear overvaluation of the retirement benefits, at least based upon their tax exemption, ${ }^{262}$ and it assumed that $\mathrm{H}$ valued $\$ 10,000$ of retirement benefits as the equivalent of $\$ 10,000$ of regular savings, which is a very optimistic assumption. ${ }^{263}$ Generally, employee surplus would be a much smaller fraction of the cost of benefits.

When willing employees do enjoy employee surplus, the next factor is the fraction of the surplus that is captured by the employer as employer surplus. In order to capture employer surplus, the employer must charge an implicit price that exceeds its costs for the retirement benefits. ${ }^{264}$ The economics studies about the shifting of the costs of employee benefits to employees find that the largest portion of the costs are shifted to employees. There is no indication that employees accept compensating differentials, i.e., pay implicit prices, that exceed

${ }^{261}$ See Example 2 supra p.

${ }^{262}$ See supra note ___ and accompanying text.

${ }^{263}$ Retirement benefits are subject to numerous restrictions and penalties if they are withdrawn prior to the plan participant attaining age 55. See I.R.C. $§ 72(t)$ (2000 \& Supp. 200_).

${ }^{264}$ See supra note 135 and accompanying text. 
the costs of the benefits. ${ }^{265}$ If this is accurate, employers are not capturing any of the employee surplus.

Likewise, when a retirement plan creates productivity gains, the question is what fraction of these gains is retained by the sponsoring employer. On this point, some economics studies indicate that some of the productivity gains are shifted to employees. ${ }^{266}$ Thus, employers are apparently retaining only a portion of the productivity gains.

Standardized compensation packages and retirement benefits pose another impediment to the capture of surplus and gains by an employer. All employees in a particular job or at a particular compensation level receive standardized amounts of salary and retirement benefits. An employer cannot charge individual willing employees higher implicit prices for their retirement benefits depending upon the strength of their preference for the benefits, nor can it charge individual reluctant employees lower prices. At the higher end of the employer's compensation distribution, this means that it will forgo many opportunities to capture employer surplus.

Finally, if willing employees comprise only a small proportion of an employer's workforce, there is only a limited potential for employer surplus and productivity gains. All these factors suggest that an employer that sponsors a retirement plan may be unlikely to capture significant amounts of employer surplus and productivity gains. This limits the extent to which a plan can provide mandated benefits.

The second reason that the benefit allocation rules have at best only a weak effect is that the surplus and gains that the employer does capture will not necessarily result in nonhighly compensated employees receiving a significant increase in their levels of benefits. Even if an employer captures surplus and gains, these resources will not necessarily be applied to buy mandated benefits for nonhighlies. Buying mandated benefits is an inefficient use of resources; these resources are likely to yield higher returns if they are applied to price reductions for customers or to expand capital investments. When these resources are used to buy mandated benefits for reluctant employees, they more or less wasted because the reluctant employees disvalue the benefits. Thus, the purchase of mandated benefits may well be the least productive

${ }^{265}$ See supra note and accompanying text.

${ }^{266}$ As to the productivity gains, it is probable that some portions of them are captured by the employees that participate in the retirement plan as increased compensation. This is 
use to which these resources might be applied; employers generally will seek to avoid buying mandated benefits for reluctant employees. ${ }^{267}$

An employer buys mandated benefits for reluctant employees only because that is required by the benefit allocation rules as a condition of providing highly compensated employees with benefit levels that more closely approach their preferences. Even when an employer does allocate some of the surplus and gains to fund additional benefits for nonhighlies, it may find that it is not feasible to raise the benefits level of nonhighlies to a rate that would be high enough to approach the rate preferred by highlies. The amount of surplus and gains available to fund benefits for nonhighlies is limited, but it must be allocated uniformly across all nonhighlies. If there is a high proportion of nonhighlies in the employer's workforce, any surplus and gains that are spent to buy benefits for them will be spread over a relatively large number of nonhighlies and thus result in a small increase in the rate of benefits for nonhighlies. Employers with a high proportion of nonhighlies in its workforce will have little opportunity to raise the benefits level of nonhighlies by a sufficient amount to accommodate the preferences of highlies. The incentive of providing higher levels of benefits to highlies will be ineffective for many sponsoring employers.

Standardized compensation packages and retirement benefits also pose an impediment to the most efficient allocation of surplus and gains by an employer. Because the employees receive standardized compensation packages and standardized retirement benefits, an employer cannot distinguish between the nonhighly compensated employees who are reluctant employees and those who are willing employees. All participating nonhighlies receive the rate of benefits that is necessary for compliance with the benefit allocation rules. Thrifty nonhighlies who would be willing to pay sufficient implicit prices for their benefits may receive the benefits at little or no cost to themselves because other employees in the group are reluctant employees. The limited amount of employer surplus and productivity gains that is available is diluted across all

suggested by the fact that retirement plans have been associated with compensation premiums. ${ }^{267}$ This may seem to be a statement of the obvious since the reason that the benefits must be mandated is that employers will not voluntarily provide the benefits. However, it is important to remember that employers do voluntarily provide benefits to reluctant employees because reluctant employees place little or no value on the benefits and hence are unwilling to pay for the benefits. 
nonhighly compensated employees; it cannot be concentrated on the reluctant nonhighlies where it might materially increase the rate of benefits for nonhighlies, and hence for highlies.

These factors suggest that the limited amounts of surplus and gains that an employer might capture will usually result in only small increases in retirement benefits for nonhighlies beyond what they would have bought for themselves. To the extent that the benefit allocation rules have any effects, the effects will be weak.

\section{E. Reforms in the Benefit Allocation Rules That Aim To Increase Benefits for Nonhighly Compensated Employees Will Decrease Benefits}

The last three sections explain that the benefit allocation rules will have no effect at all on many or most retirement plans and that in the few plans that are affected by the rules, the rules will cause only small increases in the retirement benefits received by nonhighly compensated employees. These propositions are validated by the fact that the retirement plan system provides little in the way of retirement benefits for lower-paid employees. ${ }^{268}$ The fundamental explanation for the failure of the benefit allocation rules is that in a voluntary retirement plan system, employees' preferences and choices will control the amounts of retirement benefits that they buy; legal rules cannot compel reluctant employees to buy more retirement benefits than they want so long as employees are free to choose employment with an employer that provides no retirement benefits and employers are free to offer employment that does not include retirement benefits. The benefit allocation rules are fundamentally ineffective.

Much of the scholarship about retirement plan law proceeds from an entirely different view of the benefit allocation rules. Commentators often recite the data that lower-paid employees do not receive retirement benefits and suggest that this situation can be improved by reforms that tighten the benefit allocation rules. ${ }^{269}$ Participation requirements could be shortened.

${ }^{268}$ See supra note 164 and accompanying text.

${ }^{269}$ See Halperin, Special Tax Treatment, supra note, at 37-42 (suggesting a requirement that a plan must cover all of the sponsoring employer's employees); Bankman, Tax Policy and Retirement Income, supra note, at 824-25 ("The exclusion of low-paid workers from companysponsored plans might be addressed through tighter participation and coverage rules-a process advocated by many legal scholars and policy makers."); Colleen E. Medill, Targeted Pension Reform, 27 J. Legis. 1 (2001); Russell K. Osgood, Qualified Pension and Profit-Sharing Plan Vesting: Revolution Not Reform, 59 B.U.L. Rev. 457 (1979); David A. Pratt, Nor Rhyme Nor Reason: Simplifying Defined Contribution Plans, 49 Buff. L. Rev. 741 (2001); Lorraine A. 
Coverage rules could be extended so that more employees become participants.

Nondiscrimination rules could require greater equality between the benefits of nonhighly and highly compensated employees; that is, the amounts of disparity between the benefit rates of nonhighlies and highlies could be reduced. ${ }^{270}$ Vesting rules could be accelerated. All of these proposals have in common the goal of providing additional retirement benefits to nonhighly compensated employees, and advocates apparently assume that the proposals would have their intended effects. Some authors acknowledge that additional retirement benefits imply additional costs and that additional costs may cause the termination of some retirement plans; however, termination of plans is generally not judged to be a serious problem. ${ }^{271}$ Most commentators seem to believe that incremental tightening of the rules would improve the private retirement plan system by expanding benefits for nonhighly compensated employees.

This conventional understanding about the effects of reforms of the benefit allocation rules has it backwards. Reforms that tighten the benefit allocation rules either will have no effect on, or will decrease, the retirement benefits received by nonhighly compensated employees, and they will decrease the benefits received by highly compensated employees. ${ }^{272}$ This is the fifth

Schmall, Keeping Employer Promises When Relational Incentives No Longer Pertain: "Right Sizing" and Employee Benefits, 68 Geo. Wash. L. Rev. 276 (2000); Norman P. Stein, An Alphabet Soup Agenda for Reform of the Internal Revenue Code and ERISA Provisions Applicable to Qualified Deferred Compensation Plans, 56 SMU L. Rev. 627 (2003).

${ }^{270}$ For example, it has been proposed by that the disparity permitted by the Social Security integration rules be reduced or eliminated.

${ }^{271}$ See, e.g., Halperin, Special Tax Treatment, supra note, at 5 ("But there may be limits to how far one can push a voluntary program.") In fact sometimes the termination of some retirement plans is seen as a positive outcome; some commentators question whether a retirement plan that provides some substantial fraction of its benefits to highly compensated employees is an appropriate recipient of the tax subsidy associated with retirement benefits.

272 This generalization must be qualified with the condition that the legislation does not include provisions that increase the quantity of benefits that willing employees, especially highly compensated employees, may receive, or that increase the value of retirement benefits for willing employees. For example, if in addition to requiring participation for additional nonhighly compensated employees, the legislation also increased the maximum permitted disparity between the benefits of nonhighly and highly compensated employees, then the legislation would not decrease the retirement benefits of plan participants. Seldom do proposals aimed at increasing the benefits of nonhighly compensated employees also include suggestions for increasing benefits of highly compensated employees. But see Halperin, Special Tax Treatment, supra note , at 37-38 ("If [enactment of broader coverage rules] threatens the existence of qualified plans, perhaps qualified plans can be made more attractive by providing increased benefits, for example, by allowing additional contributions for the highly compensated employees, or 
limitation of retirement plan law: reforms in the benefit allocation rules that aim to increase benefits for nonhighly compensated employees will instead decrease benefits.

The counterproductive effects of reforms in the benefit allocation rules can be illustrated with examples. Example 6 assumes that the benefit allocation rules are reformed by reducing the permitted disparity from 4 percentage points to 1 point. Assume first for simplicity that the employer captures no employer surplus and that all the productivity gains have been captured by the employees.

\section{Example 6}

Without Employer Surplus and Productivity Gains, Reduction of the Amount of Permitted Disparity Decreases Benefits of Highly Compensated Employees

Facts: Before the reform, the facts are the same as in Example 4. Highly compensated employee $\mathrm{H} 2$ buys retirement benefits that cost $10 \%$ of her salary. Nonhighly compensated employees N3 and N4 buy benefits that cost $6 \%$ of their salaries; the $6 \%$ rate is the highest that $\mathrm{N} 3$ and $\mathrm{N} 4$ will pay for.

A disparity of 4 percentage points is permitted.

Reform of the benefit allocation rules occurs; permitted disparity is reduced to 1 percentage point. ${ }^{273}$

Conclusions: Since there is no employer surplus or productivity gains, the benefits of $\mathrm{N} 3$ and $\mathrm{N} 4$ cannot be increased to $9 \%$.

Instead, the benefits level of $\mathrm{H} 2$ must be reduced to $7 \%$.

In the absence of employer surplus and productivity gains, a reform of the benefit allocation rules will have no effect on the benefits of nonhighlies but will decrease the benefit allocation rules of highlies. Fundamentally, this example once again illustrates that the benefit allocation rules cannot compel nonhighly compensated employees to buy more retirement benefits than they are willing to pay for.

Next, assume that before the reform, the employer had been capturing employer surplus and productivity gains and that all of the surplus and gains arose from retirement benefits provided to the highly compensated employee. ${ }^{274}$

somehow limiting or reimbursing administrative costs.")

${ }^{273}$ Typically the aim of such a reduction in permitted disparity would be to increase the rate of benefits for the nonhighly compensated employees to a $9 \%$ level.

${ }^{274}$ All employer surplus is attributable to benefits provided to H3. In the example, N4 


\section{Example 7}

\section{Reduction of the Amount of Permitted Disparity \\ Decreases Benefits of All Plan Participants}

Facts: Before the reform, three employees participate in a retirement plan. Highly compensated employee $\mathrm{H} 6$ buys retirement benefits that cost $12 \%$ of her salary. Nonhighly compensated employees N7 and N8 receive benefits at a rate equal to $8 \%$ of their salaries. N7 and N8 pay implicit prices equal to $6 \%$ of their salaries; employer surplus and productivity gains are used to fund the additional 2 percentage points of retirement benefits for N7 and N8.

A disparity of 4 percentage points is permitted.

Reform of the benefit allocation rules occurs. The rules are reformed by reducing the permitted disparity to 1 percentage point. ${ }^{275}$

Conclusions: In a first iteration, the benefits of $\mathrm{H6}$ are reduced to $9 \%$.

However, the reduction in H6's benefits reduces the employer surplus and productivity gains. There is no longer adequate surplus and gains to fund 2 percentage points of benefits for $\mathrm{N} 7$ and N8.

In a second iteration, the benefits of $\mathrm{N} 7$ and N8 are reduced to 7\%, and the benefits of $\mathrm{H} 6$ to $8 \%$.

When nonhighlies' retirement benefits are, in effect, funded by providing benefits to highlies, reduction of the benefits of highlies causes a reduction in the benefits of nonhighlies. (The percentage numbers used and magnitudes of change are entirely arbitrary; they illustrate the directions of changes. $)^{276}$

Example 7 illustrates that there is an interrelationship between the level of benefits provided to highlies, the employer surplus and productivity gains generated by those benefits, and the mandated benefits provided to nonhighly compensated employees. Under a given set of benefit allocation rules, each retirement plan attains an equilibrium between the benefit levels of highlies and nonhighlies. When a new legal rule reduces the benefit level of highlies, this

and N5 are paying implicit prices that are less than the cost of their benefits. It is realistic to assume that productivity gains also arise from $\mathrm{H} 3$; since $\mathrm{N} 4$ and $\mathrm{N} 5$ are unwilling to pay for all the retirement benefits that they receive, they do not value them highly and it is unlikely they would be motivated to increase productivity by receipt of the benefits.

275 Typically the aim of such a reduction in permitted disparity would be to increase the rate of benefits for the nonhighly compensated employees to a $9 \%$ level.

${ }^{276}$ Also in Example 8, the numbers illustrate directions of change; magnitudes are entirely arbitrary. 
equilibrium is upset and benefits levels must be adjusted to reach a new equilibrium at lower levels of benefits for all employees. ${ }^{277}$

Another type of reform of the benefit allocation rules that is often proposed is a revision of the participation or coverage rules; revised rules could require that more of an employer's nonhighly compensated employees must be covered by a retirement plan.

\section{Example 8}

Mandated Coverage of More Employees

Decreases Benefits of All Plan Participants

Facts: Before the reform, three employees participate in a retirement plan. Highly compensated employee $\mathrm{H} 9$ buys retirement benefits that cost $12 \%$ of her salary. Nonhighly compensated employees $\mathrm{N} 10$ and N11 receive benefits at a rate equal to $8 \%$ of their salaries. A disparity of 4 percentage points is permitted.

N10 and N11 pay implicit prices equal to $6 \%$ of their salaries; employer surplus and productivity gains are used to fund the additional 2 percentage points of retirement benefits for $\mathrm{N} 10$ and N11.

Reform of the benefit allocation rules occurs. The rules are reformed so that the plan must now cover another nonhighly compensated employee, R12.

R12 is a completely reluctant employee; she will not pay anything toward her retirement benefits. ${ }^{278}$

Conclusions: In a first iteration, the employer surplus and productivity gains that were funding 2 percentage points of benefits for both N10 and N11 must be reallocated to provide benefits for R12.

Assume that because of standardized compensation packages and retirement benefits, all nonhighly compensated employees will receive the same amounts of salary and retirement benefits.

The employer surplus and productivity gains provide N10, N11, and R2 with benefits at a $1.3 \%$ rate. $^{279}$

${ }^{277}$ Wolk, Discrimination Rules, supra note 26, at (discussing this equilibrium).

${ }^{278}$ This is a realistic assumption. If R12 had been willing to pay an amount for retirement benefits, her employer would have extended plan coverage to include her since the employer could have provided her with a compensation package that she perceived as more valuable without increasing its compensation costs. Similarly if there had been (sufficient) productivity gains to capture, the plan would have included R12 and provided them benefits at least in the amounts paid for by the productivity gains. This would again have allowed the employer to provide R12 with a more valuable compensation package at no additional cost to it.

${ }^{279}$ A more optimistic assumption would be that the compensation packages of N10 and N11 could be differentiated from R12's package. In this case N10 and N11 would continue to pay implicit prices of $6 \%$ and to receive benefits at a $6 \%$ rate. The employer surplus and productivity gains would fund benefits for R12 receives benefits at a $4 \%$ rate. The average 
H9's benefits must be reduced to $5.3 \%$. Assume that this substantial reduction in benefits for $\mathrm{H} 9$ causes a substantial reduction in surplus and gains.

After further iterations, the plan reaches an equilibrium with nonhighlies receiving benefits at a $1 \%$ rate and the highly receiving a $5 \%$ rate. $^{280}$

Note that this example assumes that employer surplus and productivity gains are available for funding mandated benefits; if there were no surplus and gains, the requirement that a plan cover a reluctant employee who would not pay anything for retirement benefits would result in the termination of the plan. ${ }^{281}$ There would simply be no funding for the reluctant employee's benefits. Also note that when surplus and gains are allocated away from nonhighlies who are willing to pay for benefits up to a certain level and to nonhighlies who are completely reluctant, the effect is to cause a substantial decrease in the benefits levels for nonhighlies, in this example from $8 \%$ to $1 \%$, because of the standardization of salary and retirement benefits for a group of employees.

These examples illustrate that reforms of the benefit allocation rules will not increase the benefits of nonhighlies and will decrease benefits if any benefits were being funded with employer surplus or productivity gains. In contrast, the conventional understanding of such reform proposals assumes that the reforms will enhance the benefits of nonhighlies. Often a reform proposal is accompanied by an acknowledgment that additional benefitswill increase a

benefit percentage for the nonhighlies, N10, N11, and R2, is 5.3\%. $((6 \%+6 \%+4 \%) / 3=5.3 \%$. Cf. I.R.C. $\S 410(b)(2)(B) ~(2000 \&$ Supp. _ 200_)). In this case H9's benefits are reduced to 9.3\% in a first iteration and the plan could achieve an equilibrium at rates of benefits higher than in Example

${ }^{280}$ This example of permitted disparity is probably unrealistic in the context of existing law. For example, under the integration rules the maximum permitted disparity on these facts would likely be 1 percentage point. See I.R.C. § 401(1)(2)(A) (2000 \& Supp.__ 200_). Thus H9's benefit rate would have to be reduced to $2 \%$, which would substantially reduce surplus and gains.

${ }^{281}$ Termination of the retirement plan obviously deprives all other plan participants of their retirement benefits as well. An alternative and even more detrimental consequence to $\mathrm{R}$ might be that she loses her job entirely. The employer might replace $\mathrm{R}$ (and other lower paid employees) with additional capital investment while retaining higher income employees who would be willing to pay for $10 \%$ retirement benefits. Joseph Bankman, The Effect of AntiDiscrimination Provisions, supra note, at . These negative outcomes emphasize the fact that mandated benefits in the context of voluntary retirement plans are not really mandatory. In our voluntary retirement plan system, mandated benefits really mean benefits that are mandatory 
sponsoring employer's cost of maintaining its retirement plan. Usually this observation is followed by a claim that any cost increases associated with the reform will be small and are unlikely to have a material effect on employer sponsorship of retirement plans generally or on overall benefit levels. The claim that benefit allocation mandates can be expanded without reducing retirement benefits may be premised on beliefs that somehow employers will "absorb" or "pass along" the costs of increased benefits and that retirement plans will continue unchanged (except for providing mandated benefits). These beliefs are wrong. Employers do not bear the costs of retirement plans. The costs of retirement benefits are borne by the participating employees or they are paid from employer surplus and productivity gains created by plan sponsorship. A law that mandates that certain employees receive certain benefits is an attempt to cause an employee to take (a larger) part of her compensation in the form of retirement benefits. In a voluntary retirement plan system, if an employee does not want retirement benefits, a legislative mandate will not change the amount of benefits that she buys.

\section{Conclusion}

This article has analyzed how the voluntary aspects of our retirement plan system pose fundamental limitations on the power of law to provide employees with retirement benefits. The voluntary nature of employer sponsorship of a retirement plan is widely understood. The focus of this article on the central importance of employees' voluntary choices and preferences in the determination of the amounts of retirement benefits included in their compensation packages demonstrates that employees ultimately control whether or not they receive retirement benefits. This suggests that retirement plan law will have little potency in providing employees with increased retirement benefits.

The theory of employee control of retirement benefits implies that when retirement plan law improves the quality of retirement benefits, lower-paid employees will be driven out of the retirement plan system. The theory also implies that the present benefit allocation rules are largely an exercise in futility and that most proposed reforms of the rules will aggravate the very problems the reforms are intended to solve. Beyond these two conclusions, this theory of

only for so long as the retirement plan is continued. 
employee determination of retirement benefits will undoubtedly result in many other fundamental revisions to our understanding of retirement plan law. 